\title{
CO-CONSTRUCTING POWER RELATIONS IN A COMMUNITY COLLEGE MATHEMATICS CLASSROOM
}

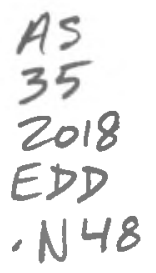

\author{
A dissertation submitted to the faculty of \\ San Francisco State University \\ In partial fulfillment of \\ The Requirements for \\ The Degree
}

Doctor of Education
In
Educational Leadership

by

Vanson Nguyen

San Francisco, California

June 2018 
Copyright by

Vanson Nguyen

2018 


\section{CERTIFICATION OF APPROVAL}

I certify that I have read Co-Constructing Power Relations in a Community College Mathematics Classroom by Vanson Nguyen, and that in my opinion this work meets the criteria for approving a dissertation submitted in partial fulfillment of the requirements for the degree: Doctor of Education in Educational Leadership at San Francisco State University.

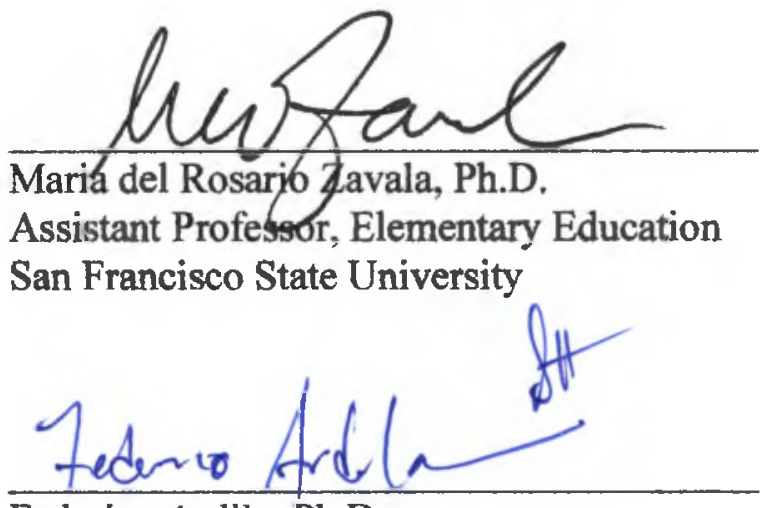

Federico Ardila, Ph.D.

Professor, Mathematics

San Francisco State University

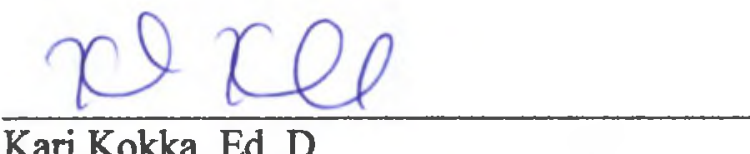

Kari Kokka, Ed. D

Assistant Professor, Mathematics Education

University of Pittsburgh 


\title{
CO-CONSTRUCTING POWER RELATIONS IN A COMMUNITY COLLEGE MATHEMATICS CLASSROOM
}

\author{
Vanson Nguyen \\ San Francisco State University \\ 2018
}

The purpose of this study was to examine power relations in the community college classroom utilizing Freire's theory of co-construction and Foucault's theory of power. Through practitioner research, qualitative data suggested that faculty have power in the class and should reflect on their experiences as students to create opportunities for participation. Also, co-construction may provide avenues to increase participation and development of mathematical knowledge among students of color.

Leadership recommendations for creating and sustaining a co-construction in community college mathematics classrooms are: 1) providing training for faculty to transform their classrooms, 2) developing communities of practice for continuous growth, and 3) social justice leadership focused on creating equitable outcomes for students of color. As a result, students of color will have access to learn mathematics and challenge traditional power relations that exist in mathematics classrooms.

I certify that the Abstract is a correct representation of the content of this dissertation.
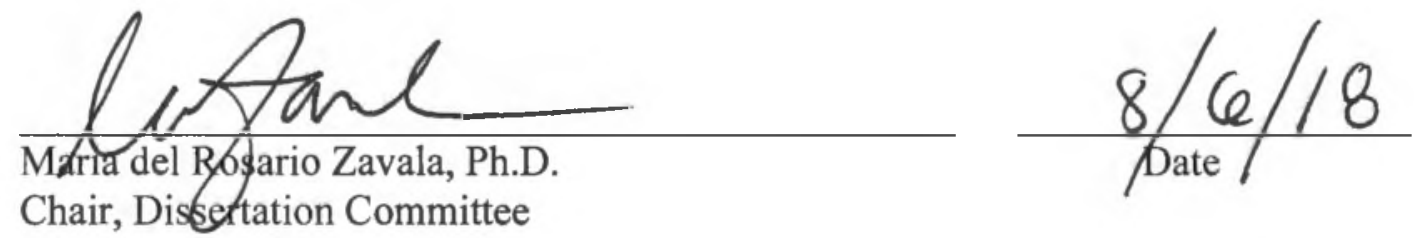


\section{ACKNOWLEDGEMENTS}

I would like to acknowledge those who have paved the way for me to be here. This includes my family, ancestors, friends, colleagues, loved ones and students.

I have to give specific shout-outs to Team Greatness, the love, support, laughs, good times and critical feedback y'all have given me. To Maria, thank you for understanding what it's like to be a math major and how hard it is to transition to writing for the academy; also thank you for being a dope critical math educator! To Kari and Federico: many, many more collaborations are coming. To the whole committee, this is only the beginning and I look forward to building more with you.

A special shout-out to my fiancée and life partner, Cheryl: thank you for supporting me and being there for me to pout, vent, hug and be a vegetable. 


\section{DEDICATION}

To all my peoples in the struggle: students past, present and future. 


\section{TABLE OF CONTENTS}

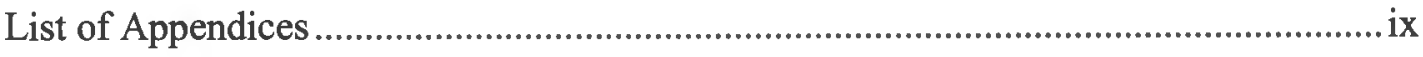

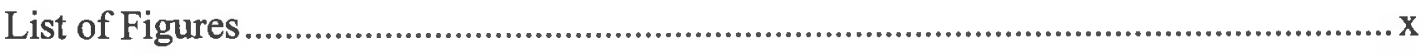

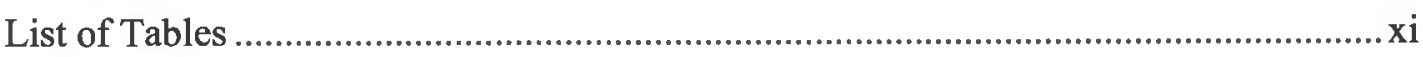

Chapter One: Introduction .................................................................................... 1

A Crisis in Community Colleges ............................................................................

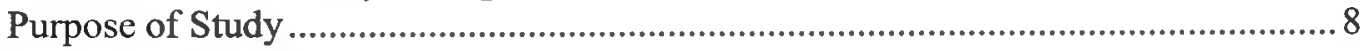

Research Question ................................................................................................ 10

Chapter Two: Literature Review .................................................................................... 12

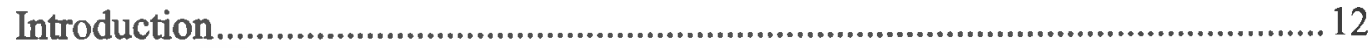

Theoretical Framework ............................................................................................ 13

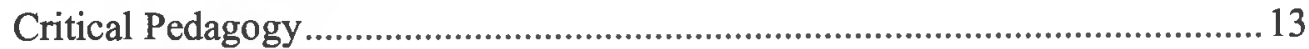

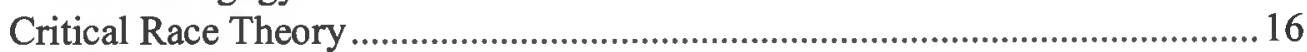

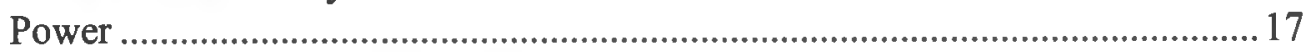

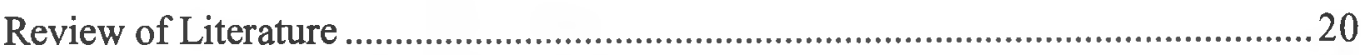

Community College Mathematics ......................................................................220

Power in the Math Classroom........................................................................22

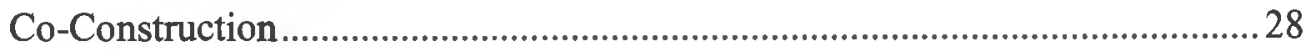

Pedagogies for Marginalized Students.................................................................33

Humanizing Pedagogy ....................................................................................33

Critical Mathematics Pedagogy …………………………..................................35

Critical Race Theory in Mathematics ............................................................38

Tensions ........................................................................................... 41

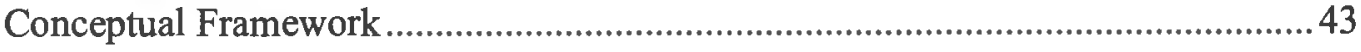

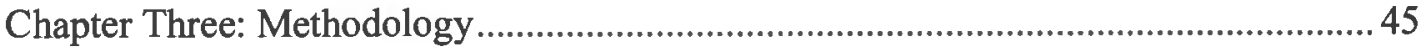

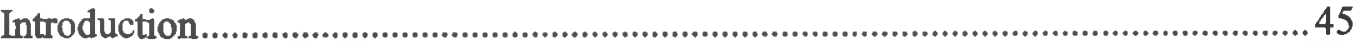

Researcher Positionality.........................................................................................48

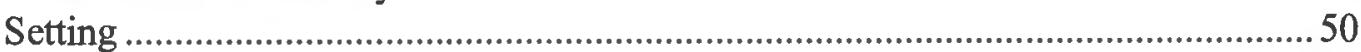

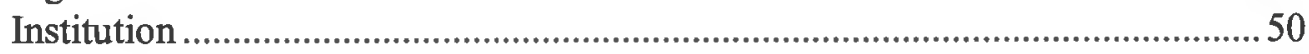

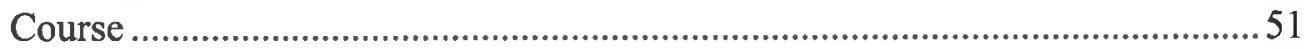

Pedagogical Approach ...................................................................................5

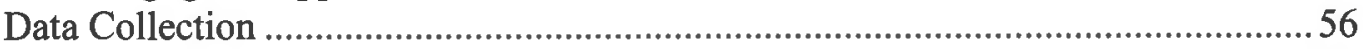

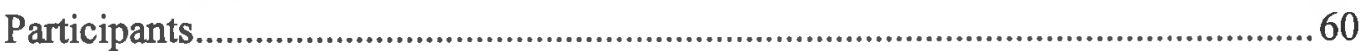

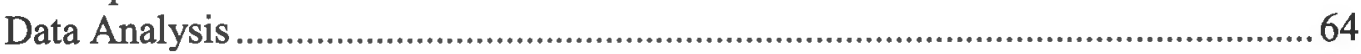




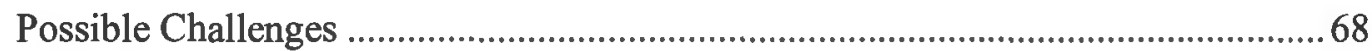

Chapter Four: Report of Findings ................................................................................ 71

Introduction........................................................................................................ 71

Section 1: Privileging Student Voice .....................................................................71

Believing Faculty Have Power ........................................................................71

Practicing Reflection and Vulnerability.............................................................74

Creating Participatory Opportunities for Marginalized Students .........................76

Section 2: Co-constructing the Classroom.............................................................78

Developing Classroom Practices ........................................................................78

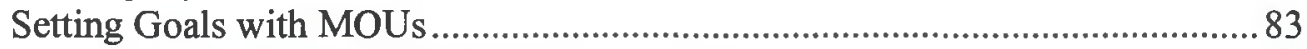

Collaborating through Whole-Class Quizzes........................................................8 89

Section 3: Using Mathematics for Critical Perspectives............................................95

Lyrical Analysis Project ............................................................................

Participatory Action Research: Improving the college ...................................... 100

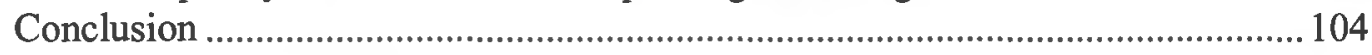

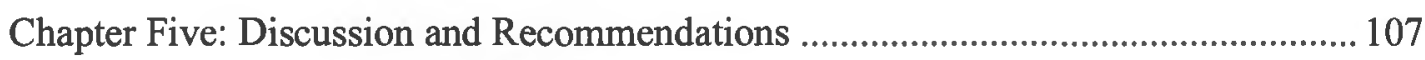

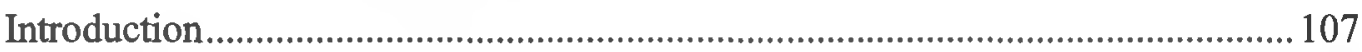

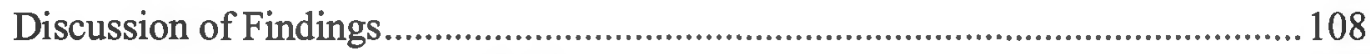

Section 1: Privileging Student Voice................................................................... 108

Section 2: Co-Constructing the Classroom.......................................................... 113

Section 3: Using Mathematics for Critical Perspectives......................................117

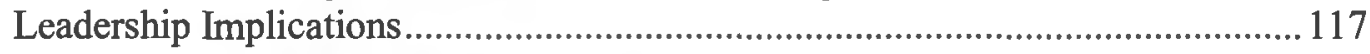

Community College Math Classrooms ........................................................119

Professional Development .................................................................................. 121

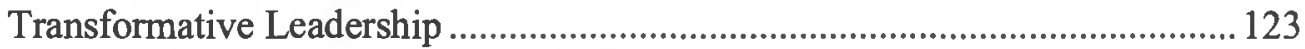

Limitations and Recommendations for Research ..................................................... 127

Students as Co-Researchers, Co-Authors ...................................................... 128

Teaching Mathematics for Social Justice in Community Colleges ................... 128

Co-construction Methodological Variations.....................................................129

Reflections as a Scholar-Practitioner (Praxis Discussion)....................................... 130

Teaching and Studying Math, Transition to Social Science ............................... 131

Imposter syndrome; connection with students.................................................. 132

Scholar-practitioner tensions (positionality \& spectrum) ................................... 133

Conclusion ................................................................................................. 135

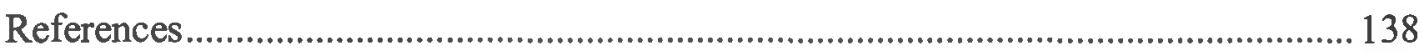

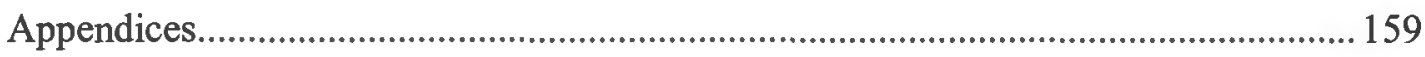




\section{LIST OF APPENDICES}

Appendix Page

A. Student Interview Protocol ............................................................................... 158

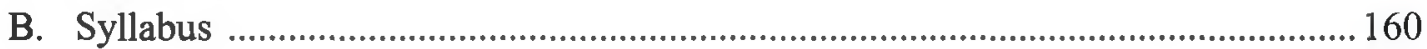

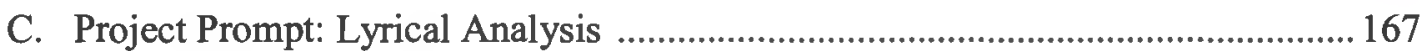

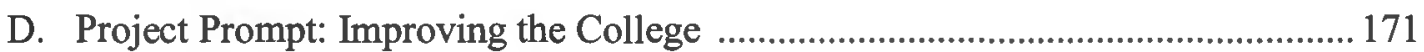

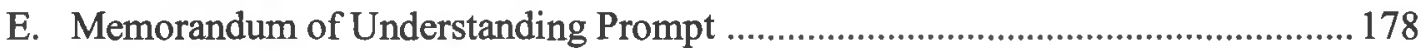

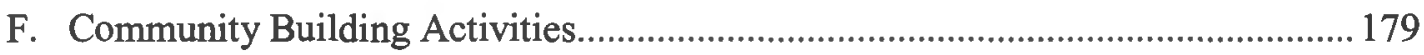




\section{LIST OF FIGURES}

Figure

Page

1. Traditional Model of Power................................................................................ 20

2. Co-Constructed Model of Power .......................................................................... 43

3. Student Interactions in Whole-Class Quizzes ........................................................ 94

4. Histogram Showing Counts of References in Kanye West Album ........................... 98

5. Histogram Showing Counts of References in Future Album ................................. 98 
Table

\section{LIST OF TABLES}

1. Data Sources and Analytic Questions................................................................56

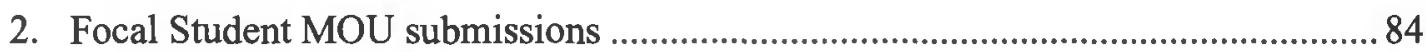

3. Student Projects: Lyrical Analysis..............................................................................99

4. Student Projects: Participatory Action Research ....................................................... 101

5. Logic Model for Next Steps ................................................................................. 127 


\section{Chapter One: Introduction}

\section{A Crisis in Community Colleges}

The ways that community colleges operate contribute barriers to students achieving their academic goals, particularly students of color. Many immigrant and low-income students attend California community colleges (Dougherty \& Karen, 2005). Upon entry, all students must take a placement exam to initially place them into a mathematics and English course to determine which course to take. Over half of African-American and Latino community college students have to initially take a math course three levels below a college-level course, typically arithmetic or pre-algebra (Perry, Bahr, Rosin \& Woodward, 2010). At the state level, California Community College students who place three or more levels below college-level have a $6 \%$ change to complete a college-level course within 3 years of first taking a math course (California Community College Chancellor's Office, n.d.). It is possible that some students change their academic goals of transfer to vocational majors that require less mathematics and may skew the data to lower percentages of completing college-level mathematics. Although these statistics are for the whole state of California, the current research project takes place at one of California's 115 community colleges.

College on the Island (COI) is the smallest of four community college in the Flatlands Community College District (FCCD). The district offices and two of the colleges in FCCD are in a large urban city of Bistoun whereas $\mathrm{COI}$ is in a small 
suburban island next door. Many students from Bistoun enroll in courses at COI. Following a cohort over a course of 6 years, only $36.6 \%$ of COI students who did not place into college-level Math and/or English were able to receive an Associate's degree, certificate or transfer to a 4-year university within 6 years (Scorecard, 2016). This makes sense because the increased number of courses students must take to achieve college-level or degree-applicable mathematics courses lengthens the time they spend in school and raises the amount spent on tuition and books. Combined with statewide trends on placement and progress through completing a college-level course, these statistics show that students of color in particular are not achieving degree completion or transfer to universities. This low degree attainment is possibly by design.

Scholars have long argued that schools are a primary mechanism for reproducing social class structures (Bourdieu, 1973; Bourdieu \& Passeron, 1990). In particular, there is a capital needed to succeed in academics because the existing culture and values within higher education replicate that of the dominant class. This is what Bourdieu (1973) refers to as social capital and cultural capital: the skills and knowledge needed to navigate and succeed in schools. In fact, Delpit (1992) argues that education was designed for middle-class white students, leaving students of color out needing to figure out how to succeed in academics. This theory of social reproduction starts in the early grades. 
Social reproduction has been found in schools starting as early as elementary school. In Anyon's (1980) study of students attending elementary schools across several social classes, she found that students going to schools in the poorest areas are setup to be in the bottom rung of society while richer students going to more affluent schools are prepared to be leaders in society. This classic study suggests that schools are meant to reproduce the ideologies of the dominant (rich) class by stratifying students through a curriculum of social norms - the hidden curriculum (Apple \& King, 1977). This hidden curriculum of social reproduction indicates that students in the poorest communities are being prepared with skills that will allow them to work in the lowest paying jobs while students from the richest communities are being taught with contexts and curricular activities as if they will run their own companies (Anyon, 1980). This classic study of social reproduction applies to college settings as well.

Community colleges have traditionally been seen as a lower track of higher education. The California Education Master Plan was designed so the University of California (UC) and California State University (CSU) systems select the highest performing high school students: the top eighth of high school students go to the UC's, the top third goes to the CSU's and the rest of the students would go to community college or start working. The result of having selective institutions of higher education is that immigrant and low-income students primarily attend California community colleges; thus, community colleges primarily serve the working class of society 
(Dougherty \& Karen, 2005; Geiser \& Atkinson, 2013). In higher education, the dominant narrative about college going is completing a bachelor's degree in 4 years. The average time a community college students complete a bachelor's degree, if at all, is 6 years (Stephan, Rosenbaum \& Person, 2009). This data contributes to a misleading narrative about a community college "penalty," that community colleges lengthen the time it takes to graduate (Geiser \& Atkinson, 2013). The "penalty" doesn't account for the real life experiences that many low-income community college students of color face: survival takes precedence over school and having to put food on the table is a necessity when paying tuition reduces disposable income for basic needs such as food and rent (Aronson, 2008). The penalty is indicative of a deficit view of community college students, mostly low-income students of color, who do not fit the mold of the dominant class completing an undergraduate degree in 4 years. This stratification is by design in the state of California. Although sometimes unknowingly, faculty and counselors play out a form of this stratification in their classrooms.

The hidden curriculum of social class is taught in community colleges. A study by Callahan and Chumney (2009) looked into differences between remedial coursework done in community college versus universities within the same level of remedial English course: community college students were relegated to rote memorization through worksheets and vocabulary testing while university students were engaged in idea sharing and constructing arguments. In vocational classrooms at community 
colleges, students spend time doing repetitive work as required by industry standards; these lessons taught students that their future roles were about compliance and staying in line with authority (Valadez, 2000). These two studies are examples of how community college reproduce social class and are consistent with the findings of Anyon (1980). Student services departments can also perpetuate social reproduction by requiring full-time students to take student success courses, but not part-time students (Karp, O'Gara \& Hughes, 2008). Many low-income students must work and this policy excludes working students who enroll part-time from student success coursework. The studies looked at how the hidden curriculum operates within the classrooms, yet there are other components of a community college that implements the hidden curriculum.

A student's aspirations can be cooled out by through academic advisement. That is, community college students can be given alternative recommendations of their academic goals, often a lower track, and be convinced the new academic goal is appropriate (Clark, 1960; Clark, 1980; Deil-Amen \& Rosenbaum, 2002). This is particularly true of students who have extremely low initial placement of math and English, mostly low-income students of color, with aspirations of transferring to 4-year universities: Career Technical Education (CTE) programs allow students to complete their academic goals in a shorter period of time (Clark, 1960). Part of the funneling into CTE majors and certificates is a neo-liberal agenda: workers are needed at the lower paying jobs in industry and community colleges are the place to develop the needed 
workforce (Ayers, 2005). Within this vocational training, students are taught to stay in line, follow directions and obey authority (Apple \& King, 1977; Valadez, 2000). Although these studies argue that cooling out may not be apparent in today's community colleges, cooling out may exist in more modern ways than from its original definition over 50 years ago.

The cultural and social capital needed to navigate a college is often missing from low-income students of color (Bourdieu, 1973). This needed skill of navigation is a modern form of cooling out because students who do not have the skills will lower their aspirations (Jill, 2015). Merit arguments are also modern forms of cooling out: in a selective vocational program in a community college, minority students were found to be cooled out and drop out of the program after not being able to successfully complete coursework (Ginsberg \& Giles, 1984). Although the study was conducted in excess of 30 years ago, this meritocratic phenomenon occurs today in STEM majors where students must spend at least 3 years taking coursework, including upper-level mathematics. As a result, low-income students of color are underrepresented in these majors (Spencer \& Hand, 2015). For low-income students of color who have to take multiple remedial mathematics courses, they are convinced that the coursework is needed, that remediation is an essential development of their math skills (Deil-Amen \& Rosenbaum, 2002). Students who are being convinced that remediation or lowering 
their academic goals is appropriate for them is at the heart of cooling out today. Arguably, cooling is a form of holding power over students.

In many ways, power is enacted over students in community colleges. Foucault (1977) discusses how power relations are used to train individuals. He refers to institutions such as prisons and hospitals, but this study will focus on schools. He argues that discipline is a specific power creating individuals as objects and instruments of the exercise of power; discipline creates specializations which results in an emphasis on individualization. Through hierarchical observation and normalizing judgement, schools use the examination to objectify students, making each student a case to be trained, corrected, excluded or other disciplinary actions. In this manner, the teacher is the single gaze over the students during the exam. In traditional mathematics settings, standardized tests have been used to rank students (Geiser \& Atkinson, 2013); it is this rank through grades where students are judged and punished invariably. In the community colleges, the faculty approved placement test ranks students and requires many low-income students of color to enroll in remedial courses. Students who score low on exams have been judged negatively and seen as less smart. These consequences exist despite the examination serving as a tool to determine students' knowledge. In community colleges and other settings of higher education, the faculty member is the one who has the power to create exams without any approval of an administrator. 
Because the examination is a repeated ritual of power, faculty have the power in the classroom particularly in classes with heavy grade weighting on exams.

\section{Purpose of study}

As a result of cooling out and the design of educational systems, students of color end up at the bottom of the educational pipeline. A possible reason is the power difference between students and faculty in the classroom. This research study's purpose was to see how power relations between students and faculty can be broken down with an emphasis on students of color. As noted earlier, low-income students of color succeed and graduate at low rates. However, the discussion about completion and degree attainment is insufficient in transforming oppressive structures.

Despite the dismal completion rates for students of color, graduation does not necessarily guarantee larger societal change. Gutstein (2010) argues that degree completion will not change low wages for people of color overall despite baccalaureate attainment. In her critique of neoliberalism in urban educational settings, Lipman (2012) indicates that "schooling is organized around productivity and preparing a global competitive workforce, not human development and social responsibility" (pp. 13). Creating workers who cannot critically investigate or act on elitist, racist, sexist and other oppressive structures further perpetuates social reproduction. This is why Gutierrez (2013) argues that teachers need political knowledge: faculty must be able to critique oppressive structures and assist marginalized students in development of critical 
consciousness, giving students tools to critically view the world and act upon their rules for a more socially just society.

The traditional definition of academic success has been critiqued across critical mathematics scholars. Gutierrez (2013) argues that self-actualization is rarely a measure of success; schooling does not prescribe this type of definition. Kokka (2015) questions the definition of success where she uses Gutierrez (2002) and Gutstein (2006) to describe the complementary components of mathematics: dominant (traditional measures of success) and critical (issues of power and marginalized students). Spencer and Hand (2015) discuss how math was created by and for middle to upper class white communities thus racializing mathematics education. They further argue that merit based arguments about grades automatically put students of color at a disadvantage. Using existing measures of success such as grades and graduation rates do not critique the system that excludes low-income students of color. As early as ten years ago, Gutierrez (2008) warned of a "gap-gazing fetish", hyper-focusing on achievement gaps while leaving out bigger picture issues related to marginalized students, ignoring intersectional identities of students and the oppressive structures they face. Instead of simply investigating low-achievement rates on the surface such as mastery, educators should also look at measures of advancement. She further suggested a research agenda that focuses less on the achievement gap and more on the research of effective practices of African-American, Latinx, working class and other marginalized students (Gutierrez, 
2008). In part due to this body of work, the current study will not focus on grades and instead on the power relations that exist in community college math classrooms, a needed area of research (Aguirre, Herbel-Eisenmann, Celedon-Pattichis, Civil, Wilkerson, Stephan, Pape \& Clements, 2017; Bartell \& Johnson, 2013). Low-income students of color have been held down by educational institutions and investigating power relations in the classroom can disrupt the oppression.

There are several ways to attack oppressive classrooms. Kokka (2015) suggests three components of social justice mathematics: using math to empower minoritized communities, access to rigorous mathematics and co-constructing the classroom. Looking at the last component, this study was designed to investigate how traditional power relations are impacted when the class is co-constructed. Because the faculty member has so much power in the class, the sharing and distributing of authority in the classroom with students takes a direct path towards challenging traditional power relations. Particularly, this study looked to work towards a pedagogy of co-construction. Given the grim outcomes for students of color in community colleges, there is a need to better understand how power plays out in gatekeeping mathematics courses. This paper took up the question of how to study a shift in power dynamics using critical pedagogy, specifically co-construction. The research question for this study is: "how does co-construction impact power relations in a community college mathematics classroom?" In this dissertation, I discuss theoretical frameworks of critical pedagogy 
and power relations. Then, I review literature on community college mathematics classroom and co-construction, mostly in mathematics courses. Then, I review literature on power which leads into the literature that describes the ways to serve underserved populations in schools: using critical pedagogy as a framework for critical mathematics pedagogy as a means of engaging students to improve student outcomes for low-income students and students of color. Following, I describe tensions of teaching mathematics social justice. Next, I describe my methods for gathering data and how they relate to the research question. After, I explain the data sources and analyze the data to determine major findings. Finally, I discuss the findings connecting them to the literature, provide leadership implications based on leadership frameworks and recommendations for research. As conducting the study has been a reflective process, I will also share a reflection as a scholar-practitioner. 


\section{Chapter Two: Literature Review}

\section{Introduction}

In this review of literature, various components of the study will be investigated. My research question is: how does co-construction impact power relations in a community college mathematics class? Starting with theoretical bases of Freire and Foucault, I review frameworks of critical pedagogy, co-construction, humanizing pedagogy and power relations. Then, I discuss literature on co-construction in mathematics classes, power, community college mathematics and critical pedagogy in addition to mathematical applications of critical pedagogies and similar branches that support students of color. This review will tie together somewhat differing ideologies, although there is some overlap, and connect areas not frequently addressed in existing literature. In particular, there is little to no research in community college mathematics regarding co-construction. Therefore, much of the research reviewed here is situated in $\mathrm{K}-12$ settings. This may be fitting because much of the mathematics content taught in high schools is also taught in community colleges and have some connection. Additionally, much work has been documented on critical mathematics pedagogy in $\mathrm{K}$ 12 classrooms while very little has been conducted in higher education (for notable exception, see Frankenstein, 1990). That's not to say it cannot exist in community college; although they don't call out critical pedagogy explicitly, authors of research in 
community college math classrooms have findings that align with tenets of critical pedagogy.

\section{Theoretical Framework}

\section{Critical Pedagogy}

In critiquing traditional methods of teaching, Freire (1970) argued that the dehumanization of education is manifested through the teacher who believes that students have no knowledge and need information to be deposited, thus the term banking. This model assumes that the teacher is the holder of all knowledge and expertise, and has all of the power in the classroom. In contrast to the banking model of education where students are seen as empty receptacles who should be deposited with information, teachers should utilize problem posing which grounds learning in the lives of oppressed students (Freire, 1970). Consequently, he argued the need for participatory action research where students investigate solutions to the problems they face in their communities. Critical pedagogy addresses the material conditions of the needs of students, developing critical consciousness to understand and take actions on the systems that oppress them. In addition to critical consciousness and problem posing, Freire argued that countering this oppressive form of education requires the teacher to learn alongside the students, being the guide on the side, to co-construct knowledge utilizing the experiences and expertise of both students and teachers. The current 
research study utilized co-construction as a means of breaking down power relations in the classroom.

Freire (1970) called for a stop to the dehumanization process that education inflicts on oppressed students. Bartolome (1994) explicitly suggested a humanizing pedagogy that utilizes the strengths of students' lived experiences to be the center of the learning process. This pedagogy echoes the problem-posing and co-construction that Freire (1970) suggests, yet he did not explicitly coin the terms. A humanizing pedagogy in community colleges would include faculty listening to the stories of student and faculty giving space for students to be themselves and be heard (Bartolome, 1994). Salazar (2013) added to the existing definition of humanizing pedagogy in her literature review including the development of the whole person, journey towards critical consciousness, critical reflection and responsibility of educators to promote this type of pedagogy. All of these pedagogical stances humanize students, bridging otherwise exclusionary, traditional relationships between students and faculty; the process of humanization brings together individuals as a collective in the classroom which includes students amongst their peers as well as the faculty member and is a central component of co-construction.

Applying Freire's theory to mathematics, Skovsmose (1985) discussed the need for critical mathematics education where students control the educational process and curriculum connects with social situations and conflicts determined by economic and 
political factors. He later argued that math can be used in a similar manner as literacy to be critical of social institutions and policies (Skovsmose, 1994). Frankenstein and Powell (1989) described four major goals of critical mathematics education:

1. Understanding the mathematics

2. Understanding the mathematics of political knowledge

3. Understanding the politics of mathematics knowledge

4. Understanding the politics of knowledge.

Traditionally seen as a neutral subject, mathematics can be used to teach critical consciousness and give students tools to address their oppressed situations (Brantlinger, 2013; Frankenstein, 1990; Gutierrez, 2013; Gutstein, 2008). Further, Gutierrez (2017) argues that all teaching is political and math teachers especially can be intentional about including political contexts in their math classrooms. These scholars primarily addressed items one and two of the critical mathematical curriculum stated above while incorporating the other items. Although much of the critical math education research highlights development of critical consciousness, the researchers built relationships and co-constructed much of the mathematics and projects with their students as a means to this (Brantlinger, 2013; Frankenstein, 1990; Gutierrez, 2013; Gutstein, 2008). The course in the current research study used mathematics to develop critical consciousness, but I chose to focus on co-construction and student involvement as a means of breaking 
down power relations between students and faculty. My study looked to address items three and four specifically through co-constructing the course.

In community colleges, faculty have much of the power when creating their classroom. Although their curriculum is approved by universities for articulation, what occurs in the classroom is ultimately up to faculty. There is little accountability on how classes are taught, an indication of the power that faculty have in traditional models of education where faculty are seen as experts and students as empty receptacles. This power can be shared with students through co-constructing of the classroom in particular policies, mathematical knowledge and learning environment.

\section{Critical Race Theory}

Scholars have argued that the context in which critical pedagogy was developed lacks a racial component. Ladson-Billings and Tate (1995) argued that existing work in the South (United States) to empower African-Americans is aligned with critical pedagogy as described by Freire (1970). However, Gutstein (2008) argued that although Freirian critical pedagogy was founded on class oppression, it lacked problematizing racial issues despite Brazil having a large population of African descent. The need to address race is necessary to achieve equitable outcomes and Critical Race Theory may help fill this gap.

Critical Race Theory (CRT) was designed to critique the criminal justice system and has been used as a tool to analyze inequities in school (Ladson-Billings \& Tate, 
1995). The authors suggested that property rights, including intellectual property such as curriculum, were saved for the elites of capitalism and further argued that race plays a major factor in educational outcomes. Scholars took a step further in how critical race theory applies to education: to challenge the dominant ideology, commit to social justice and build from existing experiential knowledge, a concept also found in critical pedagogy (Solorzano \& Yosso, 2002). In particular, they advocated for the use of counter storytelling to give voice to those who have been marginalized and debunk deficit narratives of people of color. The next section looks at power in different ways. Power

Power is defined to be as the ability to modify, use and destroy things (Foucault, 1982). Although community college students have to pay to be in the classroom while faculty are paid to be in the same space, students have little to no say about what can occur in their classrooms. Faculty have the power to determine policies and content, and consequently the learning environment. Usually, faculty create their courses with consultation of other faculty or faculty created documents like syllabi or course outlines; these documents are rarely created with student input. Thus, traditional mathematics classrooms are created fully within the power of the faculty. Faculty create exams without consultation of administration or students, giving even more power to faculty. The power relations created through the examination creates and controls individuality (Foucault, 2012). To break these power relations, this study investigated 
how a faculty member co-constructed classroom policies, learning environment and content.

Different from power relations, but similar to them are power dynamics. French and Raven (1959) described several different power bases. Reward power is based on the ability to reward; in the classroom, students are rewarded with desirable grades and positive interactions from their teacher. Coercive power is the expectation that an individual will be punished if there is not compliance. In the classroom, this power is most commonly used to suspend students for disruptive behavior. Legitimate power is complex, but can be explained as power through norms and values. Teachers have appropriate credentials to teach a class and students see teachers as holders of power. Referent power is based on the ability of identifying with another. Teachers who reflect their students in any fashion or can connect with students well are often given referent power by students who can see these teachers as mentors or extensions of themselves. Expert power is given when an extent of knowledge is bestowed upon an individual and this is particularly true in community colleges where faculty are content experts.

The bases of power defined by French and Raven (1959) are categorical and separate concepts of power dynamics. Usually, there are multiple power bases at play in any given situation in a classroom, but the focus is between two individuals. Foucault's (1982) theory on power relations is slightly different in that it looks at relations between systems, including ways of thinking and epistemology, and I will be using this theory of 
power. If I were to choose one of the power bases of French and Raven (1959), I would choose to focus on coercive power that faculty have over students to create compliant behavior which can easily be conflated with learning. Researchers have used these bases to look at the classroom, particularly classroom management (Kearney, Plax, Richmond \& McCroskey, 1985). Although there is not much need for classroom management in community colleges, I am particularly interested in seeing how engagement functions as an effective classroom management tool, which points directly to my research question. Term "management" suggests that students need someone to control them, a deficit view of students.

This review of theory on power builds a foundation that will help frame the study which was designed to break traditional power relations in the classroom between students and faculty. Students have little say in a system where they have to pay tuition while faculty are paid to be there; higher education was not designed to give power to students. Using Foucault's (1982) definition of power create and modify components of the classroom including exams, a traditional conceptual framework describes how faculty have all the power: they create the classroom policies, learning environment and knowledge which are imposed on students (see figure 1). 


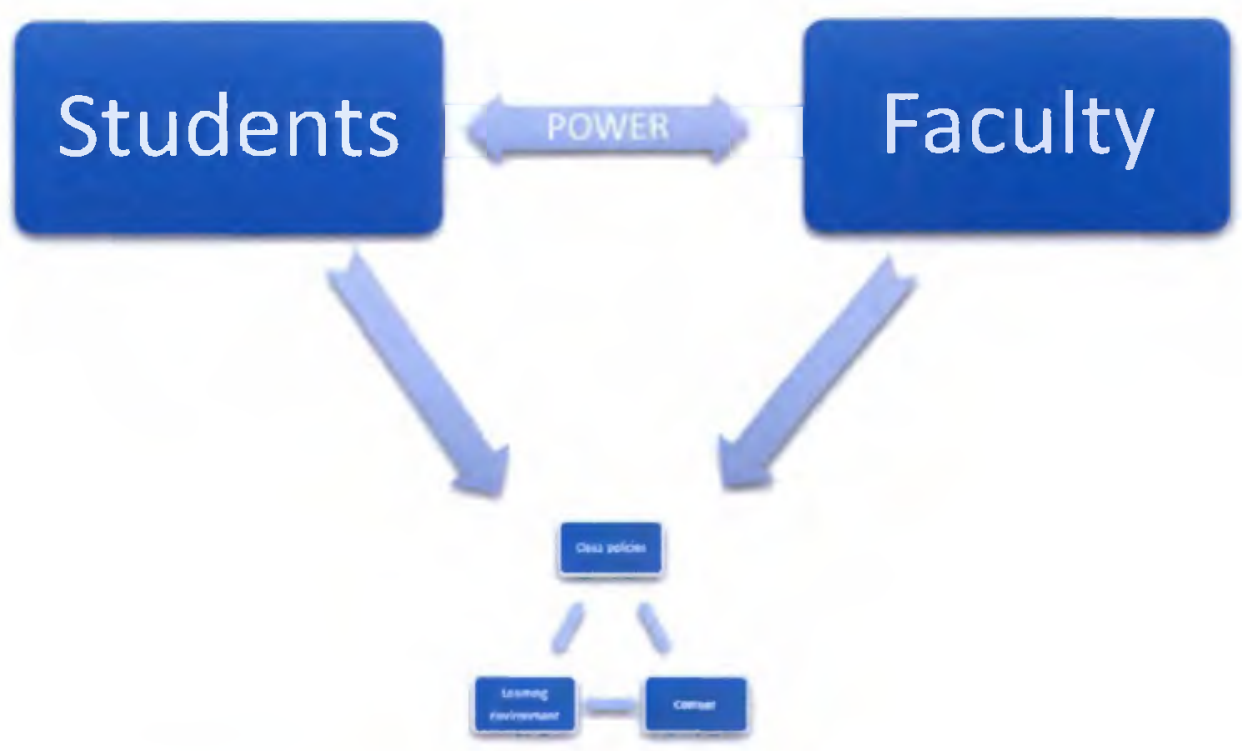

The next section describes literature about mathematics classrooms in community colleges.

\section{Review of Literature}

\section{Community College Mathematics}

This study was conducted in a community college mathematics classroom. Most of the research on community college math class does not reflect a critical perspective of education, but some findings do align with critical theory. Prerequisite to teaching, graduate math programs that funnel potential into the community college teaching profession often do not have pedagogy courses, unlike K-12 credential or mathematics education programs where graduate students may have opportunities to teach with the support of a mentor faculty. In addition, no formal teaching preparation is required for 
community college teachers (Cohen \& Brawer, 2003; Twombly \& Townsend, 2008). With little instruction on how to provide effective teaching, mathematics graduate students who become community college professors typically fall back on traditional teaching methods with long lectures, subsequently replicating their own learning experience; these traditional modes of instruction reproduce social class stratification and educational disparities (Anyon, 1980). This section discusses literature on the traditional nature of community college mathematics while highlighting how these same classrooms can be spaces where critical pedagogy can occur.

Community colleges have taught mathematics in traditional manners. Grubb (2010) investigated 140 remedial classes (including mathematics) at thirteen California community colleges. He found that math courses typically included lecture, review, individual work and problems without real world context, focusing on skills and not conceptual understanding. The instruction utilized in this study is traditional in nature and contributed to low completion percentages. On the other hand, Cox (2015) studied pre-algebra courses at two community colleges in the Northeast United States, comparing differences in instructional methods. The study found that faculty at one college used traditional, rote instruction while faculty the other college employed more student-centered activities. Success rates were lower in the traditionally taught courses as opposed to the student centered math courses. A faculty member at the college using student centered activities wanted students to feel the power, the right, and the ability to 
ask questions and develop a fundamental understanding of problem solving. The desire for students to feel power and having the right to ask questions are non-cognitive skills used in the classroom.

Prasad (2014) researched 302 community college students to investigate sense of belonging in the classroom to academic achievement. Prasad found that factors such as peer support, faculty validation and collaboration were positively correlated with sense of belonging. However, only confidence to solve math problems (or math efficacy) and math anxiety were found to affect course performance. A shortcoming of the study is that course performance was tied to traditional, psychological factors rather than those through a critical lens; there was no mention of negative perceptions of power dynamics nor a critique of traditional success measures (Gutierrez, 2013; Kokka, 2015). Critical pedagogy, however, builds agency in students to impact change on their communities.

Student perspectives in community college math classrooms have been documented as to what constitutes effective teaching. Quist (2015) interviewed a group 13 of students following completion of a community college mathematics course. The students in the study reported increased motivation for learning and a positive experience were major factors contributing to successful completion as a result of instructors who connected mathematics principles to students' lives and looked to build confidence. The confidence directly relates to self-efficacy as a predictor of course 
outcomes in Prasad's (2014) study. The findings of the study were congruent with other research connecting content to students' lives and building on students' strengths, yet the focus was on the characteristics of the faculty member. Acevedo-Gil, Santos, Alonso, and Solorzano (2015) studied five community colleges, interviewed students who were majority Latinx and almost all of the students had placed in a remedial course. The study found most students felt invalidation in academic settings through deficit thinking from faculty. However, other students found validation from faculty who addressed student strengths. This is aligned other studies that use student strengths in the classroom (Cox, 2015; Quist, 2015). These pedagogies that built on student strengths resulted in high confidence in students and academic achievement. The approaches used by faculty that start with student strengths rather than deficits show that positive outcomes can be possible without traditional pedagogy in community college math classrooms.

The above research was specifically selected to highlight how community college math classrooms can be spaces where critical pedagogy can occur and highlight the strengths of students. Confidence and efficacy are important components of a positive scholarly identity especially when students cannot connect with the mathematics content, faculty member or institution. None of the scholars looked explicitly at power relations, yet the concepts of non-cognitive components of learning 
and utilizing strengths of students point to critical perspectives. Arguably, the faculty member is the one who can create positive spaces for students.

\section{Power in the Math Classroom}

As one of the primary theories in this study, power is a fundamental concept to investigate in the relations between students and faculty. J. Gutierrez (2015) looked at a mathematics class through a single vignette of an activity. He applied Foucault (2012) to the math classroom: cognitive normalizing exists in math pedagogy through learning of content, that if students don't understand, then they are lesser individuals. He found that "the normalizing exercises of power impacts learning outcomes by mediating students' opportunities to engage the content." (pp. 99, J. Gutierrez, 2015). Students, particularly students of color, low-income and female students, can fear the judgements of others for not understanding mathematics and experience exclusion from learning mathematics. Relations of power exist between students and faculty as well as between students and students.

Explicitly, power is in the hands of the faculty. Valero (2005) defined faculty power as the ability to modify student behavior because faculty have the capacity to control students. Channeling Marx and Frankenstein, she saw mathematical empowerment as the ability to view the world through mathematics for individual gains. Empowerment was a social process that engages the disempowered to collectively build consciousness. These views on power are both micro (classroom faculty) and macro 
(epistemologies of empowerment) and apply to the system of schooling that acclimate students to their respective social classes (Bourdieu, 1973). Evans, Morgan and Tsatsaroni (2006) looked at transcripts of small groups in a math class during problem solving activities. Organically, students ended up helping each other and evaluating their work. The study found that the informal roles of helper and evaluator are positions of power among students. Faculty can give control to the less powerful students in these groups by providing explicit criteria for learning. Evans et. al, (2006) showed the potential benefits for shared power through things like co-construction of mathematics among students particularly for students who are less confident, often low-income and students of color.

Coercive power dynamics are often manifested through classroom management. The coercive power base is the use of punishment if a student is not in compliance (French \& Raven, 1959). Roache and Lewis (2011) studied hundreds of primary and secondary teachers in Australia and found that coercive, hostile behavior such as threats or reprimands from faculty can exacerbate misbehaviors of students. They also found that trust, rewards, and validation build relationships between students and teachers which collectively function as a more effective means of discipline and reducing misbehavior (Evans et al., 2006; Valero, 2005). Although set in K-12 setting, this study directly relates to community college faculty who are not trained in classroom management and may resort to coercive measures that they have seen in their own 
experiences as students (Cohen \& Brawer, 2003; Twombly \& Townsend, 2008).

Community college students vote with their feet and drop the course or stop going to class resulting in not learning the material or earning non-passing grades; low-income students of color are primarily subject to lower mathematical attainment, arguing the need to examine power relations in community college math classes.

Expert power is given to an individual when the individual is deemed an expert of some sort (French \& Raven, 1959). Amit and Fried (2005) looked at authority in an 8th grade mathematics classroom and found that students inherently gave teachers power because students perceived the teachers had expert knowledge in mathematics. This power-giving also occurred between students as those with more confidence were deemed as more of an expert because they learned the material quicker, something still common within community college students (Gutierrez, 2016; Valero, 2005). Although set in an 8th grade math classroom, this study applies to community colleges because similar dynamics can be found in adult students. Many students of color and lowincome students have been in classrooms and positioned as not knowledgeable resulting in them seeing their teachers as experts (Anyon, 1980; Freire, 1970). With so much power in the classroom, faculty have a responsibility to create spaces that are equitable for the students who need the most help.

The investigation of power can be found under other synonyms. Van Es, Hand and Mercado (2017) conducted a study on mathematics teachers noticing for equity. 
They found that teachers attended to status and positioning as well as acknowledging student histories. As students worked with each other, the teachers looked to see how to increase participation within other students and gave space for students to construct opportunities. This attentiveness and awareness to positioning, status and student background is an acknowledgement of the power that faculty have. Learning about students' histories is a means of breaking power relations to see the strengths that students bring.

Another term synonymous with power is agency. Bandura (1989) gave a definition of agency grounded in self-action, that an individual is able to influence events in their life based on exercising control. Powell (2004) extended this definition of agency to the mathematics classroom where learners take initiative engage and build with mathematics in manners that work for them, acknowledging the autonomy of the math learner. One way that he found student exhibiting mathematical agency was taking risks to develop more ideas. This is important for students of color with low-confidence that taking a risk to ask a question and potentially be seen as stupid can be embarrassing. According to Gresalfi, Martin, Hand and Greeno (2009), refraining from participating is a form of agency that a student chooses to not participate; they also argued that participation is a form of agency. In addition to determining how students act, they investigated how students were provided opportunities to participate. In their study of middle school classrooms using the Algebra Project curriculum, they found 
that agency was a function of the tasks particularly how certain tasks can create more accessibility to the mathematics (Gresalfi et al., 2009). Faculty have the power to create spaces and structures for increased participation which can build students' agency (Evans et al., 2006; Valero, 2005; Van Es et al., 2017).

Power exists in several ways in the classroom: between students and faculty as well as between students and each other (Gutierrez, 2015; Valero, 2005). Community college faculty have the power to create their classrooms in ways that are traditional in nature or engaging for students of color. Faculty can create opportunities for students to positively exercise their mathematical agency towards participation for learning. Coconstruction is possibly be a way towards distributing power away from faculty to students.

\section{Co-construction}

Co-construction, a primary construct in the current research study, is a form of breaking the traditional teacher-student hierarchy and transforming the dynamics to a teacher-as-student, student-as-teacher relationship (Freire, 1970). With co-construction, traditional power relations between faculty and students are disrupted and can result in more positive outcomes for low-income students of color. My study was situated in a community college math class and the literature is sparse on co-construction in higher education mathematics classes. As there exists very little documentation about co- 
construction in community college mathematics classes, I will share research on coconstruction in K-12 math classes and non-math courses in higher education.

Middle school mathematics classrooms have used co-construction. Chen (2016) as a participant-observer intentionally co-constructed mathematics content in her 8th grade classroom in Taiwan through small group activities and using the native language of students. This proved to inspire students to learn mathematics. Clarke (2004) also looked at 8th grade classrooms, but in Australia. There, the teachers used coconstructed the practice of learning mathematics, jointly collaborating on mathematical tasks as teachers walked around and questioned or supported students. Mueller (2009) conducted a study about an after school program for inner-city middle school students. She found that collaborative tasks and community building were necessary components to generate co-construction of mathematical arguments between students. These three studies show how co-construction in math settings increase engagement and access to mathematical learning. The research may apply to the community college setting in some ways as middle school mathematics is taught in community colleges, however the current research study was situated in a classroom with a much more diverse age group of adults. The studies here should be highlighted for their possibility of content coconstruction in mathematics.

Many courses in the high school mathematics sequence can be found in community college. The exceptions are senior level elective courses which can vary by 
high school. Russo (2015) conducted practitioner action research in his quantitative literacy course for high school seniors who struggled in Algebra. In this elective course, he utilized co-construction to develop the course and had several findings: students and teachers needed time to adjust to a co-constructed classroom and co-construction resulted in increased participation, interest and ownership of learning. Although quantitative literacy classes aren't always taught in community colleges, the students in Russo's study greatly reflect students who do go to community colleges: students who struggle with Algebra.

Even in more traditional mathematics courses, co-construction has positive results. Langer-Osuna (2009) looked in depth at the figured world of a 9th grade Algebra classroom. In this study, students were treated as professionals and given agency and choice over their activities and ideas; co-construction was used to treat students as professionals and intentionally to develop agency. Within collaborative projects, she found that using out-of-school knowledge to connect to content helped reengage a disengaged student (Quist, 2015). She further argued that multiple identities must be addressed holistically which cannot be done without regular discourse between student and faculty; the faculty member must have a relationship and platform (the projects) to learn what could possibly pique this student's interest to increase engagement. 
Co-construction has been researched in relation to other kinds of learning. HeydMetzuyanim (2013) investigated learning disabilities of a low-achieving student in a 7th grade math classroom where the teacher and student both saw deficits in the student and were found to co-construct a mathematics disability narrative within the student. Although the student was able to perform some of the mathematical tasks, ultimately the student bought into the idea that she could not be successful in mathematics as every interaction between the student and teacher contributed to negative views of the student's ability. The teacher had the authority and power to possibly create a different narrative for the student. Hand (2010) looked at a high school classroom and how the students and teacher co-constructed opposition. She found that diminished access to mathematics, polarizing participation and weak practices and identities of students contributed to the opposition; the teacher utilized negative behavior labels which . negatively impacted mathematics participation. In both of these contexts, the teacher had deficit views of students resulting in negative experiences in the classroom, coconstructing the learning environment through deficit views of the faculty member (Acevedo-Gil et al., 2015). Although these studies weren't focused on mathematical learning, the emphasis on co-constructed behaviors and narratives in non-productive ways point to engagement, or lack thereof, in learning mathematics.

In higher education, there is slightly more autonomy in running one's class because of the lack of testing pressure and academic freedom; the result is that co- 
construction can occur with much more intention. Ahn and Class (2015) interviewed students and faculty around the co-construction of a midterm exam in a university. The purpose was to situate students as agents in their own learning (Langer-Osuna, 2009). The students initially were resistant to this process, but found the activity useful and were appreciative of the opportunity. Additionally, the students reported being prepared for the exam as they were required to be experts of differing chapters. The faculty member, the first author of the article, did not give in to student desires of being spoon fed information and committed to the process (Russo, 2015). She found that students were accountable to each other as they had to collaboratively make decisions. In this case, the students were granted opportunities to teach each other to co-construct the exam. Although the research was not situated in a math course, the co-construction of this type is useful for students in community colleges.

Research has been conducted in math classrooms across $\mathrm{K}-12$ settings investigating co-construction of mathematical content with positive outcomes (Chen, 2016; Langer-Osuna, 2009; Mueller, 2009; Russo, 2015). There have been times where mathematics classrooms have co-constructed non-mathematical learning in the form of deficit views of students (Hand, 2010; Heyd-Metzuyanim, 2013). These studies did not speak to the urgency of using co-construction in mathematics coursework nor were situated in higher education settings. Additional research has been conducted in higher education, but not in math classrooms also with positive results (Ahn \& Class, 2011). 
This research study looked at the intersection of co-construction in mathematics and higher education, particularly in the community college context. In most of the studies, the faculty member had created or initiated the co-construction, whether for mathematical learning, increased engagement or otherwise. In the current research study, I intentionally used co-construction to generate knowledge, policies and positive learning environments to embolden power within low-income students and students of color.

\section{Pedagogies for Marginalized Students}

\section{Humanizing Pedagogy}

The humanization of education grounds curriculum in the lived experiences of students (Bartolome, 1994; Freire, 1970). Salazar (2013) extended the concept of humanizing pedagogy calling for educators to ground their practice in the investigation of power and privilege through the inclusion of voices of students as well as grounding practice in the lived experiences of students and teachers. She suggested the need for students in co-creating humanizing pedagogy because they are the primary individuals subject to oppression through the education system and will provide the best feedback on how to improve their educational experiences. Franquiz and Salazar (2004) studied academic resilience in Chicano/Latino 5 year ethnographic study of high school Chicano/Latino students. Students were seen as individuals with problems, but having educators who are trusting role models that give nurturing advice was found to be 
important Quist, 2015). While the study was situation in a high school, their equity focus on Chicano/Latino students is relevant to my study that also looks to in privileging student voice and experience in educational research. The authors suggested that faculty should acknowledge the social-political experiences of students and use those experiences to improve the classroom.

Humanizing pedagogy can work to both humanize students and the faculty member. Cordell (2017) interviewed 10 self-icientified African-American students and recent graduates. Looking to determine characteristics of higher education faculty that will improve outcomes for African-American students, she found that faculty selfdisclosure was a means of building relationships by humanizing faculty in the eyes of the students (Langer-Osuna, 2009; Roache \& Lewis, 2011; Salazar, 2004; Van es et al., 2017). Sometimes self-disclosure is hard for faculty, especially those who have not had the time to reflect on what may be productive to share with students. Yet, vulnerability can show that mistakes are an important part of learning.

In her talk at a recent Critical Issues on Mathematics Education conference, Gutierrez (2018) called for the rehumanizing of mathematics. She indicated that all students are "math people" until schooling tells students that they're not. Four primary factors are provided in what rehumanizing mathematics may look like:

1. Participation and positioning.

2. Cultures and histories 
3. Windows and mirrors

4. Living practice

These factors align with other critical scholars' work on pedagogy (Bartolome, 1994; Freire, 1970). The current research study aligned with the first item, participation and positioning, that investigated hierarchies and authority in the classroom with the teacher being aware of positioning. When faculty acknowledge participation and positioning, they give space for students to be meaning makers rather than the faculty being the allknowing expert.

Humanizing pedagogy is a critical component in providing access and engaging students of color with mathematics where there is major underrepresentation of lowincome students of color. This literature is of particular importance in mathematics as much of the existing curriculum does not connect to the lives of oppressed students nor give them a critical perspective on how to view the world; instead, mathematics in schools today was designed to create engineers for the military industrial complex (Tate, 2004). Traditional classrooms rob students of their humanity by teaching them that they have no mathematical knowledge (Gutierrez, 2018).

\section{Critical Mathematics Pedagogy}

Also rooted in critical pedagogy is critical mathematics pedagogy where one is able to read and write the world through mathematics (Freire, 1970; Gutstein, 2008). As the current mathematics curriculum has been designed to support military growth after 
the National Defense Education Act of 1958, much of the applications are physics, science and business based (Tate, 2004). Many of the scholars in this section use mathematics to build critical consciousness, but also utilize other major components of critical pedagogy including using student experiences and strengths as a foundation for learning, co-construction and relationship building.

Gutstein (2016) emphasized the need to synthesize the three C's of mathematical knowledge: community, critical and classical. One way to conceptualize this is that students apply their existing community knowledge and use classical mathematics to gain critical knowledge to read the world (Gutstein, 2016). These knowledge bases build critical consciousness by analyzing social, political, historical, economic and cultural structures and how they play out in students' lives through problems they face, but through the lens of mathematics (Freire, 1970). This approach relied on students' sense of social justice, which is not usually considered a valid knowledge base in the mathematics classroom.

In Brantlinger's (2013) work with high school students who were deficient on credits for graduation, he used contexts of social issues such as gun violence and economic inequality engaged the most disconnected students. He found that his creditdeficient students were discussing mathematics when prior they were disengaged with the curriculum and his course; the social contexts relating to students' lives in the units gave students connection to the mathematics and engaged them into the content. 
Gutstein (2016) researched his middle school and high school math classrooms to investigate social justice issues faced by students. Students shared their newly gained knowledge about social issues with their friends, family and their communities. These presentations and new knowledge proved to be productive for mathematical learning as the students reported that they felt they had the mathematics tools to expose injustices. In both studies, they make mention of their relationship with students, but there is an intentional component of building critical consciousness through mathematics. Both authors mentioned co-construction of some sort, but it was not the focus of either of their studies. My study looks at a classroom that looked to develop critical consciousness, but the focus was on co-construction and the power relations between student and faculty.

Frankenstein (1990) investigated her remedial college math classroom at a university to examine income disparities in race and gender as well as mathematics in politics. She suggested that social justice mathematics curriculum can get more people of color into math and science fields; it provides confidence and motivation by connecting math to the lives of students of color. Although this study occurred over 25 years ago, she is one of very few women to publish research in mathematics education on social justice in higher education. My study looked to be another study in higher education that used mathematics to teach social justice, but with an emphasis on breaking power relations. 


\section{CRT in Mathematics}

Mathematics classrooms have been researched through a CRT lens. Negative effects of deficit thinking from educators start early in students' careers. Martin (2006) interviewed African-American adults who reported that they had to advocate for themselves as students and their children to have access to resources and contest with lower expectations that would force their children into lower tracked courses in K-12 schools, fighting the dominant narrative about African-Americans being inferior. His study showed how deficit thinking negatively affects students of African-American descent and discounts experiential knowledge brought into the classroom by these students. Perhaps because education was designed for white, middle class students (Delpit, 1992), African-American students cannot connect with the schooling system and do not succeed, creating the narrative of inferiority which continues in college. The experiences of African-American university students mirror those in K-12. McGee and Martin (2011) interviewed African-American students in mathematics and engineering programs and found that these students experienced negative racial stereotypes of not belonging in these demanding majors. Like in Martin's study (2006), the students in these universities faced social experiences where others, peers and faculty, felt that African-American students were inferior when learning or succeeding in mathematics. Despite facing constant negativity, the participants reported a growth in self-understanding and connected their academic achievement to personal goals as well 
as being a mentor to younger African-Americans or giving back by creating engineering programs in their communities. These students have found a critical purpose of their education: give back and help future generations of students through mentorship in hopes of building persistence in the face of negative stereotypes. This is what DuncanAndrade (2010) refers to in his letter to Freire when he discusses studying as a revolutionary act; that one studies to be able to help their community in the future. Rather than learning to earn, they were learning for freedom (Duncan-Andrade, 2010; Freire, 1970). These narrative counter the dominant ideology of degree attainment for employment purposes.

The use of counterstory is a critical race theory tenet (Solorzano \& Yosso, 2002). Terry (2011) utilized youth participatory action research (Freire, 1970) as a means of developing a counter-narrative against the need for more police and prison versus university going of black males. He referred to his students as researchers, giving them the authority and validity that a black student from a low-income neighborhood may not have been be afforded by educators (Langer-Osuna, 2009; Martin, 2006). Together, they created a counterargument to the police department's public call for more police through mathematics and challenged dominant narratives that suggest black males were more likely to go to prison than college. He found that this type of education allowed students to read the world with mathematics, something congruent with others scholars (Freire, 1970; Gutstein, 2006). The connection to the lives of 
students created opportunities to learn mathematics for young African-American students in urban schools.

Latinx students are also underrepresented in mathematics and the need to study their experiences exists. Zavala (2014) utilized a LatCrit framework and testimonio with interviews and focus groups of youth about their experiences with mathematics. She found that Latinx students are racialized beings, impacted by racial stereotypes and linguistic identities in English speaking schools. Students will find ways that work for them linguistically and faculty should give space for students to find themselves. This is important for faculty to acknowledge as their Latinx students find themselves in higher education, a system designed for white middle class students (Delpit, 1992). I suspect this is true for most students of color, yet the focus on my study will not be on identities. In higher education, Oppland-Cordell (2014) looked at calculus workshops through a multiple case study design at a university. She found that Latinx students were successful based on their participation and identity development as mathematics learners in the workshops. Thus, it is important for faculty to find ways to engage Latinx students to increase participation, positively developing their identities in mathematics learning. Although this study was conducted at a university and not a community college, the findings are important to acknowledge for community college students who make their way to calculus or are pushed out of STEM majors prior to finishing the algebra sequence. 
Much of the prior research on mathematics for social justice is in the context of K-12 classrooms or universities. Little research exists in which explicit pedagogies for marginalized populations takes place in community college mathematics classrooms However, extant research does suggest that community college mathematics classrooms can be spaces where critical pedagogy and critical race theory can be valuable tools to understand learning processes for traditionally marginalized students. Student perspectives and stories have indicated less than desirable experiences and provides a possibility as to why there is underrepresentation of students of color in mathematics (Martin, 2006; McGee \& Martin, 2011, Oppland-Cordell, 2014; Terry, 2011; Zavala, 2014). Although most research in social justice mathematics has been around looking at how mathematics can teach critical consciousness, I intentionally chose not to focus at how math can teach students how to read and write the world with mathematics; yet, the course does utilize projects and content to give students tools to critically investigate oppressive systems (Frankenstein, 1990; Gutstein, 2008).

\section{Tensions}

A pre-requisite to effectively teaching social justice mathematics is a social justice commitment or orientation in the practitioner (Gutierrez, 2009; Gutierrez, 2013; Gutstein, 2009; Gutstein, 2012; Gutstein, 2016). Mathematics is normally thought of as a politically neutral subject, playing a gatekeeper in the dominant paradigm around education and job attainment (Powell \& Frankenstein, 2002; Gutierrez, 2013). 
Negotiating is also needed for teaching to content versus teaching for social justice because students were not accustomed to social justice mathematics and content did not align with standardized tests (Bartell, 2103; Brantlinger, 2014; Frankenstein, 1990; Gregson, 2013; Gutierrez, 2006; Gutsteìn, 2016; Huerta, 2011). In the study by SimicMuller, Fernandes, and Felton-Koestler (2015), they found that preservice teachers were not willing to delve deep into social issues in their classrooms, mostly because they were ambivalent. The lack of commitment to social justice was possibly the major barrier. Perhaps a critical reflection of the preservice teachers and existing teachers could be a step towards developing the commitment. Brantinger (2014) discussed how he had a hard time answering questions related to social justice when teaching mathematics for social justice. These tensions work interdependently with one's position in the classroom.

An aspect of social justice knowledge is addressing one's positionality. As an outsider, this checking of position can bridge the students and teacher (Gutstein, 2008). It is also important to acknowledge the power in the room, that the faculty member has so much power. This is possibly a prerequisite to look to break traditional power relations. These tensions are important to acknowledge, however the potential for shifting power dynamics between students and teacher makes pursuing a study of mathematics teaching using critical theories compelling. 
The literature in this chapter outlined scholarly work on co-construction, power and tensions. There is much intersection between the theories and pedagogies as they stem from fighting oppressive structures found in the classroom. With much positive results through the investigation of student and faculty voice, this study is grounded in finding ways to break power relations through co-construction.

\section{Conceptual Framework}

Below is co-constructed model of power relations in the classroom that was used in the current research study (see figure 2).

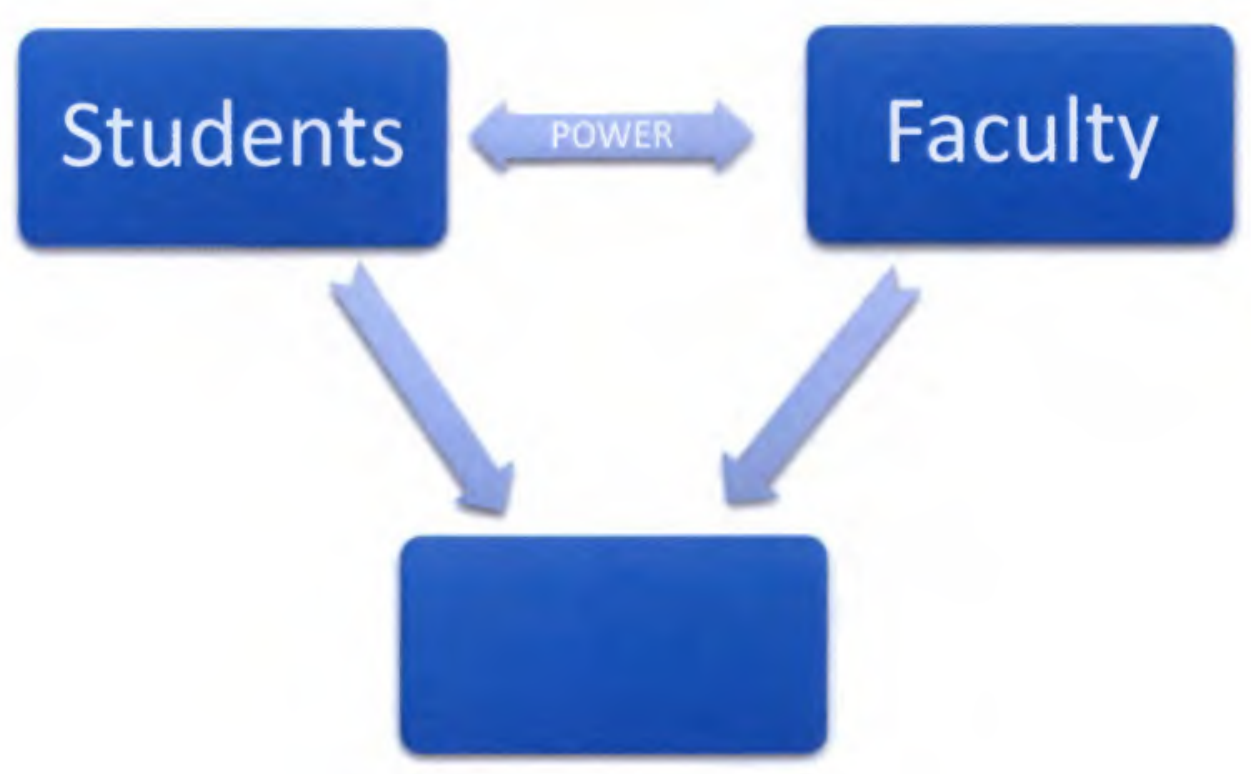

Fig. 2

Power was distributed between students and faculty who collectively define the classroom policies, mathematical knowledge and learning environment. In this model, 
students and faculty were jointly responsible and co-constructed the classroom together (Freire, 1970). Additionally, students in this model were not seen as empty receptacles to be filled with information, but instead as individuals with valuable lived experiences that should be utilized in course development (Bartolome, 1994; Ladson-Billings, 1995). The current study study began with intentional community building during the first few weeks of the term. The purpose for building community is to develop relationships between students and students in addition to students and faculty (Brantlinger, 2014; Gutstein, 2016; Martin, 2008). With a trust built within the classroom community, I expected that students will be more likely to provide honest feedback and participate with classroom activities. Moving away from lecture and incorporating collaborative learning has proved to be helpful for students with academic achievement, but also non-cognitive domains such as improving math confidence and reducing math anxiety (Prasad, 2014). However, black and latinx students can benefit from small group work when group work is structured around authentic and open-ended problems (Gutierrez, 2012). 


\section{Chapter Three: Methodology}

Introduction

Many of the students at College on the Island (COI) are from underserved, lowincome communities. My research intended to give voice to their educational experiences as a means of documenting their stories as well as validate their lived experiences as they relate to being a student at COI. Through the lens of coconstruction, I looked at the power relations in the classroom during the whole term. For the sake of this study, power relations were examined through the interplay between the students and myself, student experiences prior to and during the class under study and pedagogy in the mathematics class. The research question this study looked to answer is: How does co-construction impact power relations in a community college classroom?

In Freire's (1970) framework for teaching oppressed students, he suggested the use of co-construction to break the traditional student-teacher, teacher-student, teacheras-expert relations. One of the benefits of doing so is that co-construction gives students power to inform the classroom and their learning environments. As written in the literature review, scholars have studied co-construction in mathematics classrooms, mostly in K-12 settings, pointing to an increased reporting of student engagement (Chen, 2016; Clarke, 2004; Mueller, 2009; Russo, 2015). A missing link in the research is the use of co-construction in community college mathematics classrooms which this 
study looked to investigate. The lack of research literature inspired me to investigate the classroom where I teach.

In the spirit for Gutstein's (2006) study of low-income students, I chose to conduct practitioner research where I will look at my own practice in the classroom and utilize critical pedagogy in the classroom (Herr \& Anderson, 2014). There is little literature on critical pedagogy in community college math classrooms or coconstruction in community college math classrooms, which elicited the need for practitioner research in this study. As insiders to their study, practitioners provide an insightful perspective on what occurs in a classroom. Studying their own site or practice, practitioner researchers have a unique relationship to data collection, tacit knowledge and positionality. This is what makes practitioner research different from action research: I am researching my own practice and am, thus, an insider (Herr \& Anderson, 2014). Practitioner research can also empower the faculty member's voice. This is particularly of significance since there is so little research on critical pedagogy in community college mathematics and my voice is important in growing the field of literature. Sometimes referred to as teacher-as-researcher or participatory research, practitioner research is a reflective process and is best done collaboratively. Because of potential bias, critical friends are needed to be external "devil's advocates," questioning and pushing back against my own biases (Herr \& Anderson, 2014). Qualitative design 
is appropriate because I want to speak to how to theorize math learning in classrooms where a faculty member is trying to address power.

In my study, I have elicited two graduate school colleagues and another faculty teaching in the math department at COI as critical friends. An African-American female mathematics instructor, a colleague of mine at COI, is finishing her second year as a new full-time, tenure-track faculty member. She has a Ph.D. in mathematics from UC Berkeley and had been teaching part-time in community colleges for 1 semester before being hired on the tenure-track, but had taught at upper division mathematics at UC Berkeley for a few semesters. Another critical friend is a colleague in the EdD graduate program that I was enrolled in. He is now a close friend, our relationship developing throughout the course of the program. He is a dean of students and head counselor at a high school in an urban city nearby. He deals mostly with discipline and is studying social power dynamics and how they impact Black male scholars. Another critical friend that is a cohort-mate in the EdD program. She is a full-time English faculty member in a community college and studying prison higher education. She comes from a conservative family and community, but is very conscious and wants to serve the students who need the most help, a truly equitable philosophy. My critical friends were integral to my self-study process. They often questioned, asked me to clarify and offered different perspectives on aspects of my study design and data analysis. 


\section{Researcher positionality}

With any qualitative research, one's positionality must be addressed, particularly with practitioner research (Herr \& Anderson, 2014). Qualitative data is analyzed through perspectives which is subject to researcher bias. Rather than avoid bias, as is traditional in this form of research, I intended to seek to acknowledge my biases and took steps to triangulate data to limit the impact of bias. In this section, I will describe my position as a student, educator and researcher as they relate to the study.

I am a 37-year-old Vietnamese-American male who speaks English with an American accent; the English that I speak is a part of the dominant culture and I am perceived as young compared to other college professors. The perception of youth, my background growing up in an urban area and American accent affords me a connection to younger students that older faculty may not have. Yet, my background as a child of immigrant parents, low-income first-generation college student growing up in a multicultural urban setting allows me a unique connection to students from FCCD. Marginalized students often don't feel connected to their schooling, and being someone who can connect with urban students on multiple levels (language, culture, struggle of being poor growing up) affords me stronger relationships with my low-income students of color than someone who has grown up in the middle-class with middle-class values. My experiences as a student were not reflective of the traditional college student: I regularly faced racism and classism which lead to a development of imposter syndrome, 
something that was prevalent throughout the whole dissertation process. Imposter syndrome is where one sees themselves as a fraud; in the situation of school, I did not see myself as a scholar despite being accepted into graduate school (Clance \& Imes, 1978). My negative feelings stemming from imposter syndrome are a stark reminder of what students have to face on an everyday basis, yet they may not have tools or support system like I do now. Because of that I am more empathetic towards students, looking to build reasonable solutions for their experiences in and out of class. Sometimes the solutions are not academic related, but instead are more related to mentorship. This teaching philosophy of mentorship is characteristic of teachers who Duncan-Andrade's (2007) describes as ridas: educators who are looking to help students where they need help rather than poison and demean students (gangstas) or be ambivalent to their out-ofschool issues (wankstas). Students of color-often need non-academic assistance to persist through their academics - something that I needed as a student - and I want to provide that mentorship to other students.

Yet, I come with many privileges. Often, these privileges are unseen and I don't acknowledge them as frequent as I should. First, I come from a family of educators. In Vietnam, both of my parents were teachers and had always put a strong emphasis on education when our family moved to the US; I was born into a family of educators that already had the mindset of education as a means of social mobility which puts me at an advantage (Bourdieu, 1973). Also, my mom was able to provide me with a lot of love 
despite growing up in rural Vietnam and working countless hours during the day. The love she provided and the fact that both my parents stayed together and lived through my childhood is also a privilege. While the prior ones are more hidden, there are privileges that are more apparent: male, heterosexual, able bodied and living a middle class lifestyle. In the current political times, I must also acknowledge my privilege as a citizen of the US; I do not live in fear of deportation like some of my students nor do I live in fear of a family member being deported.

In acknowledging my positionality as a researcher and educator in this study, I affect the data in a unique manner. Because I am the individual who grades their work, students being interviewed may withhold information or provide responses that they may deem non-threatening to me in fear of me generating a bias towards them to grade them unfairly or giving substandard grades. Thus, I interviewed them after the term ended and grades were entered. For many students, the course was a terminal course: most students won't need to take another math course again and won't feel the need to appease me with specific responses.

\section{Setting}

\section{Institution}

College on the Island (COI) is the smallest of four colleges in the Flatlands Community College District (FCCD). Although situated in a suburban city, COI serves mostly students from a neighboring major urban city, Bistoun, in addition to other 
nearby cities. The college offers career education as well as general education for Associate's degrees, certificates and transfer to 4-year institutions. The Mathematics department offers roughly $65 \%$ remedial and $35 \%$ college-level courses. Like many other community colleges, many Math faculty at COI have not had pedagogy or education courses in their graduate school preparation (Cohen \& Brawer, 2003; Twombly \& Townsend, 2008).

\section{Course}

The research was conducted in a college-level Introduction to Statistics course that met twice a week at $8 \mathrm{am}$. This course was intentionally chosen because statistical content can easily relate to social contexts, namely social justice issues. On the other hand, Algebra or other courses that lead to the calculus sequence have many real world applications that are business or physics based and are worth investigating teaching for social justice. The course was a new pilot for acceleration: students were able to enroll in a college-level statistics without completing the prerequisites given that they enroll in a support course taken concurrently. The support course had a one-way co-requisite of the parent course, statistics in this case, meaning that students taking the support course must also enroll in the parent statistics course. The converse was not true: students taking a statistics course are not required to enroll in a support course. The motivation to take the support course is the opportunity to take a college-level course at any time, essentially allowing students to self-place themselves into statistics. This has led to 
many more students of color and low-income students who have placed low through the placement exam now taking a college-level course. The support course was 2 units and the parent course was 4 units, or a total of 6 hours three times a week. There were a total of 46 class meetings excluding holidays or the FLEX (professional development) day.

\section{Pedagogical Approach}

I have taught this course each semester for the past few years. The instruction and pedagogical approach I have used over time fit within a framework of coconstruction. In the course under study, I spent time building community during the first week of class. I did this because research suggests that low-income students and students of color complete courses more when they have positive relationships with their colleagues and faculty (Kohl, 1995; Ladson-Billings, 1995). On the first day of class, I facilitated small group and whole class discussion about the weighting of grade categories: projects, exams, homework and quizzes. The weighting was co-constructed between the students and me as I gave boundaries on the categories and the students created their weights through a voting process. Below were the bounds I used:

- Quiz up to $10 \%$

- Homework up to $25 \%$

- Projects at least $15 \%$

- Exams: 
- 1 exam: at least $30 \%$

- 2 exams: at least $35 \%$

- 3 exams: at least $40 \%$ (last exam replaces lower score of first two if applicable)

Students also chose the number of exams to have given the option of 1, 2 or 3 where the option of 3 exams allowed a replacement score. The syllabus is provided in Appendix A. This grade weighting activity kicked off the community building events where students shared goals (have-to/choose-to), created success quotes, and designed a phone app and culminated in generating classroom practices (norms); descriptions of the community building activities are provided in Appendix F. Together, students and I generated classroom practices (norms) that provided a foundation for how students and faculty operated in and out of the classroom. These factors collectively built a culture of collaboration and mutual respect.

Class meetings regularly consisted of activities designed to engage students. In my lesson planning, I always asked myself: how is the class going to be co-constructed and where is the power given to the students? As a result, I often utilized small group work, large group discussion and student work on the board in addition to some lecture. These multiple modes of instruction were designed to meet different preferences of learning and opened the door for co-construction of the learning environment where students would choose which style they would prefer on different days. Different topics 
elicited more time in small groups, large group discussion or lecture. When explaining requirements for a binomial probability, I lectured, yet had students help me read definitions projected onto the screen or have them read from their phones or laptops. When working with two-way contingency tables, I created small group activities for students to find probabilities. Introducing hypothesis testing required lecture initially. As the class was exposed to more types of hypothesis tests, small group activities were created working on problems where students determined which test to use and performed the appropriate hypothesis test. With lessons planned, I used another structure to promote participation.

On most days, I assigned whole-class quizzes where there is one score for the whole class and all students in attendance received full credit. The number of points was determined by student activity on the board, explanations by students of their work, mistakes by students, questions from other students and debates about concepts. This structure for class participation created opportunities for students to engage with the content while engaging with their peers and me, and also building community as we worked collaboratively. My intention was for students to view their work as part of a whole rather than as an individual. While whole-class quizzes created spaces where students and faculty co-constructed knowledge, the format of the quizzes also created a collaborative learning environment where mistakes were welcome and not punished, students learned together and the class earned points as a whole community rather than 
individually. At times, students ran the class and I facilitated conversations sometimes with the whole class and sometimes in smaller groups. Students who missed class, but communicated that they would be absent were automatically afforded half the quiz points; this policy served as a means of promoting communication and gives me information on how to serve students better.

I worked with students to develop Memorandums of Understanding (MOU), something I learned in graduate school. These were assigned just after the halfway mark of the semester and students were assigned to create goals for the remainder of the semester; they received points for checking-in with me about their goals making the assignment and process co-constructed. For full points, students wrote a reflection and checked-in with me a second time during the last week of school to discuss their progress. They could still receive full points for not meeting their goal as long as they were transparent about their progress and documented their progress in a written reflection. This second check-in also constituted as a co-construction of the assignment where each student and I worked through their progress, growth and future goals. The MOU assignment is provided in Appendix E.

Similar to Ahn and Class (2015), the in-class portion of the final exam had a problem chosen by the students, $25 \%$ of the in-class final. Of the topics that were to be covered, students chose a problem - any problem - and it would be on the exam, wordfor-word. The stipulation was that they had to solve the problem themselves and were 
allowed to put the solution on a support sheet, 1-page both sides with anything on it. In this instance, the final exam was co-constructed.

Co-construction was also built into the two major projects: lyrical analysis and improving the college. Students investigated social issues by analyzing lyrics in hip-hop albums as well as investigated ways to improve the college through student voice and finding innovative solutions. In each project, groups of students met with me in and out of the class to co-construct their topics, statistical analysis to choose the most convincing data to support an argument they create and other components such as the written report and presentation. Descriptions of the projects including prompts are provided in Appendix $\mathrm{C}$ and $\mathrm{D}$.

\section{Data Collection}

Data collection included gathering of classroom artifacts, one-on-one interviews, teaching journals and data memos. With these data sources, I privileged student voice and demonstration of student agency rather than evidence of traditional measures such as performance on exams, scores or grades. Refer to Table 1 below for data sources and what they will be analyzed for to answer my research question.

Table 1: Data Sources and Analytic Questions

Research Question: How does critical pedagogy impact power dynamics between students and faculty in a community college mathematics course?

\begin{tabular}{|l|l|l}
\hline RQ Component & Data Source & Analyze for \\
\hline
\end{tabular}




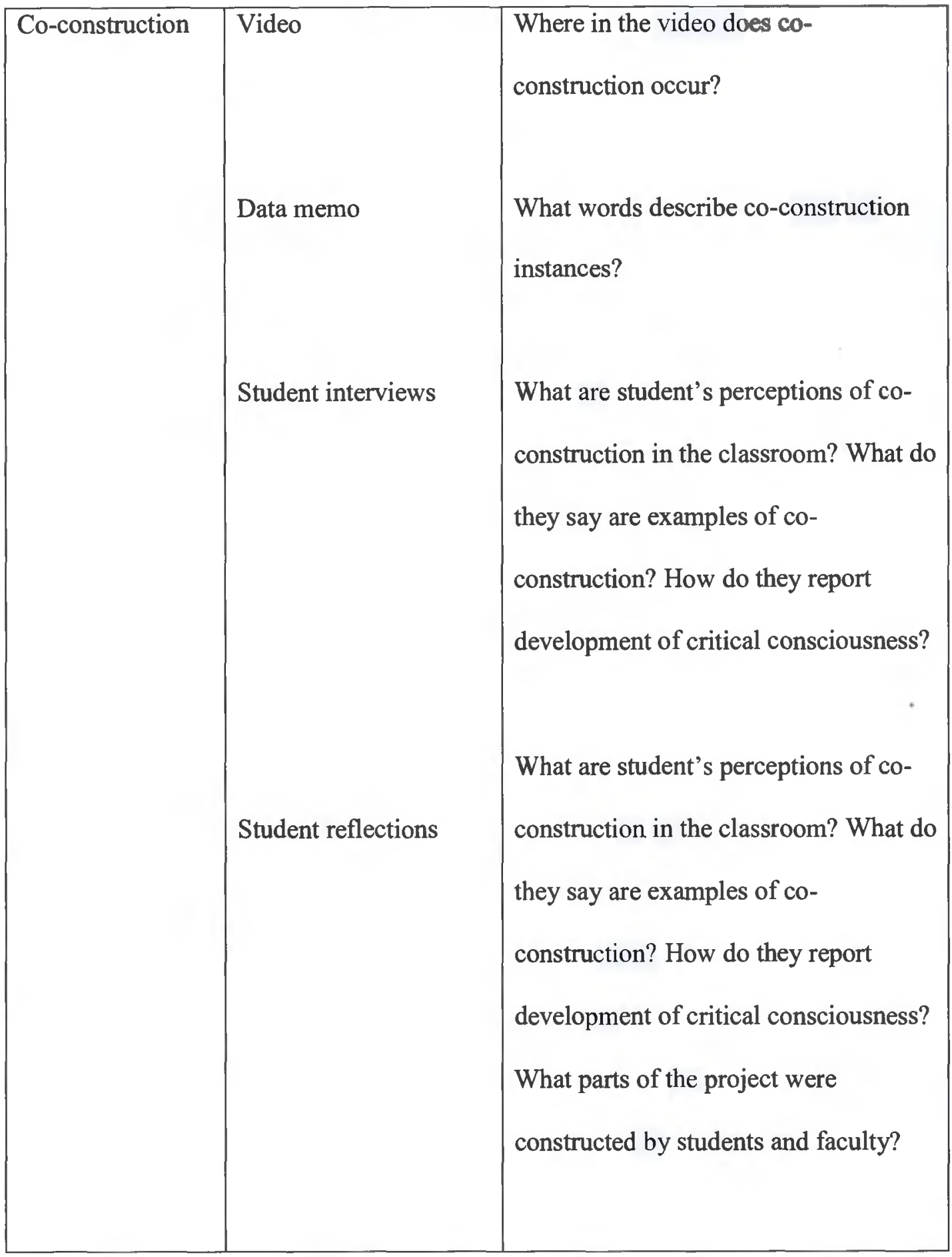




\begin{tabular}{|c|c|c|}
\hline & Classroom artifacts & \\
\hline Power dynamics & $\begin{array}{l}\text { Video } \\
\text { Data memo } \\
\text { Student interviews } \\
\text { Student reflections } \\
\text { Classroom artifacts }\end{array}$ & $\begin{array}{l}\text { How are students participating in the } \\
\text { classroom? } \\
\text { What are my perspectives on power } \\
\text { given to the students? } \\
\text { How do students perceive they have } \\
\text { power in the class? How do they } \\
\text { perceive I have power in the class? } \\
\text { does the wording give students } \\
\text { authority over the classroom? } \\
\text { How do students perceive they have } \\
\text { power in the class? How do they } \\
\text { perceive I have power in the class? }\end{array}$ \\
\hline
\end{tabular}


Classroom artifacts included syllabus, my lesson plans, project prompts, student projects, classroom practices and student entries of Memorandums of Understanding (MOU).

Purposive sampling was utilized to select students to interview (Teddlie \& Yu, 2007). I looked to find students that lived at the time, previously lived or identifies as from the nearby urban city of Bistoun in addition to being a student of color, lowincome or both. I purposively sampled students from Bistoun because of the violence, crime, poverty and other forms of oppression they faced living in the low-income neighborhoods of this city. Unlike suburban cities with low-income neighborhoods, the poor areas of this urban city are violent. Often, these students are seen through deficit lenses and their voices are not heard. Instead, I looked to privilege their voices and provide educators equitable strategies to work with these students (Saldana, 2015). Through written introductions, reflections, visits to office hours and informa] conversations, I learned which students met the criteria I was looking for and elicited their participation in interviews. 17 students were invited, all students of color from Bistoun, and 11 were interviewed. Student interviewees shared their views on the power dynamics of the course and connect it to their learning. An interview protocol is located in Appendix A. I transcribed all interviews myself, listening to each interview at least four times. This self-transcription allowed me to stay grounded in the data. 
Following each class, I wrote in a teaching journal regarding what occurred in each class and my thoughts from the interactions in class about the power dynamics and co-construction of the classroom environment. After the second week of class, my teaching journals also included lesson plans specifically how I would look to give students power and co-construct the class. Every two weeks, I wrote a data memo about the teaching journals over that period of time.

\section{Participants}

The participants in the study were students in the class and I was their instructor. The students in the classroom have either taken a placement test, taken remedial math courses or been placed into the class through multiple measures using high school GPA. These various entry points into the course created a diverse group of students in ages, ethnic backgrounds, income levels, and learning styles. This course was an open access to the college-level statistics course provided students take a co-requisite support class. As a result, most of my students came from underserved, low-income communities and live in a nearby urban city. Of the students in the class, roughly a quarter of the students have taken a class with me in the past. All students interviewed are from the nearby urban city of Bistoun known for violence, poverty and crime. They are all students of color and low-income, yet vary in ages from $18-54$.

\section{Interviewees}


Carrie is a Mexican-American female from East Bistoun and has been in FCCD for five years. She previously attended private schools for K-12 and is currently working as an after school program leader and basketball coach at her old elementary school. She is the second youngest of 4 children in her family, but identifies as a middle child with middle-child issues. She fought lack of motivation and stayed quiet in class because she didn't understand all of it in fear of sounding wrong or stupid. She is a Sociology major and wants to transfer to East Bay University. I have constantly and will continue to push her to become an educator and pursue a graduate degree. She has plans to become a teacher or a social worker in the Bay Area.

Darryl is an African-American male in his 50's from East Bistoun and is formerly incarcerated spending over 30 years behind bars. During the whole semester, he worked graveyard shift so class was his after-work endeavor. He worked with and mentored the other African-American male students at my request and is looking to transfer to a nearby CSU where he plans to major in social work. Darryl also wants to be a part of the program for formerly incarcerated students at the CSU similar to a program at COI that has provided him access and support to higher education. He plans on going to graduate school for social work and contribute to the community after graduation by opening a non-profit around entrepreneurship, mental health and social issues. 
Phuong is an Asian-American female with Vietnamese parents that have Chinese last names. That is, her father is Vietnamese, but has a Chinese last name; her mother is also Vietnamese. Her parents and siblings are immigrants, yet she was born in the US. She worked at an after school teaching program and an ice cream shop. Phuong has lived in San Leandro, but has been a resident in East Bistoun for six to seven years. She is a psychology major and looks to transfer to a popular UC nearby.

Papi is a Mexican-American male who has worked in public libraries for several years. He has attended only private Catholic schools for his K-12 academics. I have nudged him to become a librarian, work at a community college library and pursue a graduate degree. This is the third time he's taken a course with me, he's taken two courses in sequence and has repeated the stats course, the second time being the course of study in this paper. Out of his group of friends, he was the only one attending college and often found himself partying with them.

Naydea is an African-American woman looking to transfer to a Historically Black College \& University (HBCU) in Atlanta. She grew up in the Upper Tops neighborhood of West Bistoun and attended public schools in Bistoun. Majoring in business, she plans on opening up a business in the community of Bistoun, yet I have pushed her to attend graduate school and become an educator. She has considered the former, but has indicated that she will likely not become an educator. 
$2 \mathrm{~K}$ is an African-American male from Bistoun and has attended public schools all his life. He played for the men's basketball team and is currently not playing on the team, but hopes to earn a scholarship to transfer. He worked multiple jobs over the course of the semester.

Cheryl is originally from Philadelphia but lives near downtown Bistoun with her sister who is in graduate school at a nearby CSU. She works regularly and is hoping to transfer to nearby CSU majoring in Psychology. I have pushed her to go to graduate school and become an educator.

Teena is a child of immigrant parents from East Bistoun. She is the primary caretaker for her father who has been ill throughout the course of the semester causing her to miss some classes and causing some distraction. She worked regularly during the semester.

Juanita is an undocumented student graduating from a UC and took this course as a last requirement for her major in urban studies. Originally from East Bistoun, she has recently received a grant to documènt the stories of undocumented students.

Willy is an African-American male that had taken several courses with me in the past and also worked with me in the Brotherhood, a program on campus for male students of color. He has worked many service and retail jobs which has led him to come back to school. He now works at an after-school program in a communityoriented charter school in East Bistoun, but originally had desires to attain an 
Associate's Degree in Liberal Studies, but not transfer. He now is looking to transfer and I regularly push him to get a graduate degree and become an educator.

Kim is an African-American woman from East Bistoun majoring in Communications. She is looking to transfer to the closest CSU and wants to become an educator, work for the Port or become a police officer. I have, and will continue to, push her to go to graduate school.

\section{Data Analysis}

Using grounded theory (Charmaz, 2014), I transcribed all interviews, listening to each interview at least four times. The purpose was to stay grounded in the data. I coded iteratively to find emergent themes from the various data sources to answer the research question: how does co-construction impact power relations between students and faculty in a community college mathematics course? I first coded and analyzed student interviews before coding and analyzing any other data to privilege student voice. I utilized first initial coding on the interviews, using gerunds (-ing words) to describe student responses as close as possible to what they were saying and stay grounded in the data (Charmaz, 2014). I then used colors, bold, underline and strikethrough to do another first round coding of the responses, a form of structural coding (Saldana, 2015). This structural coding categorized the raw data into specific topics that would help answer my research question with categories of student power, faculty power, and co-construction. I coded student power (blue) and faculty power 
(red) as separate colors because I believed the two were mutually exclusive. I defined anything initiated by students or beneficial to students as student power and defined anything faculty initiated as faculty power. However, I coded co-construction as bold so that responses could be bolded and color coded based on student or faculty power, that responses could be both co-construction and student power or co-construction and faculty power. This process took a four iterations as I went back to my research question and found other interesting common responses that I felt worth coding (e.g. community). For example, "if something isn't working for us, if we come forward and say something, that you'd be open to that" is coded blue for student power, red for faculty power and bolded as a co-construction of learning environment, knowledge or policies. In addition, the quote "Communicate, not just like "do this do that do that." (Faculty are) choosing what they could do an affect attitude toward class" indicates that communication is co-constructed, but the rest of the quote is faculty initiated with the attitude towards class being co-constructed; none of this quote represents student power explicitly.

For a focused, second round coding, I combined my initial codes with the structural (categorical) codes to determine emergent themes from the raw data to answer the research question (Charmaz, 2014; Saldana, 2015). I used a separate set of codes from the first round structural coding to highlight the the different components of the course I was looking to co-construct based on the conceptual framework: mentions of 
learning environment was coded orange, knowledge and content was coded magenta, policies green, privileging student voice was blue, co-construction was bold, faculty initiated activities were underlined, and student initiated activities were italicized. In this manner, different parts of a code have multiple intersections of color, bold, italicizing and underlining. For example, a focused code of "students choosing percentages" is bolded, blue and green: students choosing is privileging student voice and is coded blue while percentages affect policies which is green, yet the whole theme is bolded because grade weighting (percentages) was co-constructed during the first week of school. Also, a focused code of students being able to raise hand and faculty being flexible with agenda for the dav are coded slightly differently. Both have codes of blue (privilege student voice) and orange (impacting learning environment), but the italicized codes indicates a student initiated activity (students initiate their own hand raising) whereas the underline indicates a faculty initiated activity, the faculty member creates the agenda and provides space to move agenda items around. The bolded parts indicate a co-construction. This process took five iterations of recoding and changing the colors and formatting of the codes to capture specific components of the conceptual framework. The emergent themes from the student interviews provided a foundational lens to investigate the rest of the data. To further strengthen the findings, I then selected specific data in the teaching journals that aligned with the student interviewee emergent themes. 
I coded the teaching journals using structural coding to categorize and highlight the most common themes (Saldana, 2015). In the second round of coding. I focused on the emerging structures that had the most to do with disrupting traditional power relationships and formed findings from those classroom components.

Analyzing the student projects in depth, I looked for mathematics used, content of social issues and proposed solutions. Each project was done in groups so there were a total of 13 submissions for both projects. For the final project, I documented the overall topic of the project, statistics used to make an argument for change and proposal theme With the lyrical analysis project, I documented the statistics used to construct the lyrics' connection to the group's chosen social issue. With the data, I found emergent themes of mathematics and use of mathematics to understand the world. I then used codes from prior analyses to connect data from teaching journals and interviews that aligned with themes from the student projects.

All collected and analyzed data were peer reviewed to reduce bias (Fraenkel, Wallen \& Hyun, 2015). Regular meetings with critical colleagues helped me critique my initial analysis and check my positionality. For instance, in the initial design of the project, a colleague brought up how students may provide favorable responses. My colleagues suggested interviews following the entering of final grades to minimize the fact that responses would be biased towards pleasing me as the researcher and the students' professor. Also, I wanted to investigate power relations only, but my critical 
colleagues reminded me that other themes could come up which would possibly help answer my research question such as classroom community, power amongst students or power in critical consciousness.

One term emerged as useful in my analysis, and so I will define it here: agency. Powell (2004) defines mathematical agency in the classroom as learners who take initiative to learn mathematics, developing ways that work for them. I will define agency as the propensity to speak up and voice one's opinion or the taking of action within a student to make a change to improve their situation.

\section{Possible Challenges}

There are a few challenges in the study. First, students were interviewed shortly after they have completed taking the course and grades are submitted. Despite the class still being completed, students may provide responses to interview and in-class questions they may deem non-threatening to me in fear that negative feedback would result in a bad grade. I interviewed them after the term whereas data collected from inclass activities must acknowledge the tension of the existing power dynamics between myself and the students, that their responses may sound favorable and not critical. The student interviewees generally had a positive view of me which also could have contributed to favorable responses and less critical evaluations of me. On the other hand, as the practitioner and researcher, my relationship with them built throughout the 
course of the semester meant that I would not have to spend so much time building rapport with the students during the beginning of the interview process.

I have taken several semesters of coursework on education which has transformed my classroom whereas most community college math faculty have not, whether in graduate school or as a professional. Professional development is often provided on campus and there are opportunities for professional growth through conferences and trainings. Yet they are not the same as taking education specific courses because trainings, conferences and professional development activities oncampus are often one-and-done events whereas taking an education course lasts a few months; the doctoral program I was enrolled has three years of coursework. Consequently, my findings may not be generalizable to other classrooms where the proportion of underserved students may differ from mine or a faculty member uses strategies that do not mirror critical pedagogy. My sample is small and limited to a classroom of students which contributes to the lack of generalizability, however the purposive sampling can suggest transferability to similar contexts of working with lowincome students of color in an urban community college system. This study can lead towards a classroom pedagogy through the lens of co-construction.

As community colleges serve a diverse population, there are many factors that contribute to learning. Some include having to work, family responsibilities or other life occurrences; these external factors may negatively impact students' ability to learn in 
the classroom regardless of any power they are given. Thus, I must acknowledge that students' lives outside of class may prevent certain students from attending class and benefiting from critical pedagogy or co-construction. Most things that occur in the classroom do not put food on the table that evening, drive a parent to a doctor's appointment or help pay next month's rent, all very real issues that students face on a regular basis.

This chapter discussed the methods on how I will conduct practitioner research. As someone who is studying their own practice, I elicited the help of three critical friends to minimize bias (Herr \& Anderson, 2014). The design was to privilege the voices of low-income students of color from the urban city of Bistoun. In the following chapter, I will discuss the findings from the data collected. 


\section{Chapter Four: Findings \\ Introduction}

The findings chapter is organized into two sections to allow for the design of the research: 1) to report findings that privilege the experiences of students of color in their own voices and 2) to report on the co-construction of mathematical and other knowledge in relation to the mathematics classroom. Using data sources as evidence, I will indicate how each theme and subtheme helps answer the research question: how does co-construction impact power relations in a community college classroom?

\section{Section 1: Privileging student voice}

In this theme, I looked to privilege student voice and seek their perspective on power relations, the class and their overall experience. Student interviewees were purposively sampled to all come from the low-income neighborhoods of the nearby urban city of Bistoun. This is an equitable approach to interviewing where I sought to give voice to and document the stories of low-income students of color who have not traditionally had a voice in education (Seidman, 2013).

\section{Believing faculty have power}

Surprising to me, all of the interviewees communicated a belief that faculty have power in the classroom. My surprise comes from the notion that if one must pay for something, then they should have power regarding the outcomes such as shopping for items or paying for a service where the customer is central to the experience. In higher 
education, students pay to take coursework towards earning a degree and my expectation was that students would transfer the customer mindset to paying for tuition. To illustrate the common theme, here is a quote from a student, Papi, who shared what he learned about the topic of control in the classroom when asked how much control a teacher should have in the classroom:

Papi: Teacher's should have a large amount of control. Probably like the majority; it's their class.

Vanson: Can you explain some more?

Papi: It's the instructor's class, their class, their rules. It's what I've been taught in school. (Papi, Interview, December 20, 2017)

Here, Papi spoke of the class belonging to the instructors - not the students - and how faculty create the rules; this presumes that students must follow the created rules. There is an underlying lesson that he was taught: faculty rule the class and should have most of the control. Paying for college did not change his mind to believe the classroom should belong to students. Naydea shared a symptom of being a student with faculty having control in the classroom: "I know the teachers, they wouldn't give too much power to students." (Interview, December 19, 2017). Her statement assumed that faculty have power to give, yet it seemed that she understands the power relations between students and faculty. If faculty were to give power to students, it would likely be a small amount according to Naydea. Both of these responses were strong indicators that students believe faculty have power in the classroom. 
Other student interviewees believed faculty have power in the classroom with critiques. Juanita spoke explicitly of her experiences before college around teachers having control in the classroom:

I think that when we were in high school, when we were in $\mathrm{K}-12$, it's all about the teacher having control in classroom. I think that's probably where it would have to start: stop teaching that way, stop making students feel that way. Because for me, high school was horrible. I was just feeling so controlled constantly. I had no autonomy. (Juanita Interview, December 20, 2017)

Juanita was a graduating senior from a University of California taking a community college course to finish up her math requirement and reflected on her experiences in high school compared to her experiences in higher education. While she recommended what faculty should do, she spoke more about what not to do inferring that faculty have power in the classroom to affect their classrooms. She was speaking up for other students and critiquing the schooling system whereas many of the other student interviewees have internalized the power structures resulting in students thinking of themselves as bad students (Interview, December 20, 2017). Her understanding of power structures was possibly a result of being further along her academic career than the typical community college student and she had the experience of a positive learning environment in higher education where she had autonomy in the classroom.

Growing up in poor neighborhoods, schools teach compliance rather than learning so it makes sense that the student interviewees would believe faculty have 
power in the classroom (Anyon, 1980). Students believing faculty have power in the class puts the responsibility on the faculty member to make changes towards breaking any type of power relations.

\section{Practicing reflection and vulnerability}

For faculty to begin to make change in their classrooms, they must be able to reflect on their own experiences as a student to provide spaces for student learning. This includes a replication of positive interactions and classrooms, but intentionally not duplicating their negative experiences in school.

Cheryl explained why faculty should reflect on their past experiences as students. When asked if it would be beneficial for her to have shared power among students and faculty, she initially said "I think that's how students become more confident and successful," and follows up with "having a professor that understands that, and like I said, connects with and know what it's like to struggle or just experience those types of things." (Interview, December 19, 2017). Here, she suggested that a faculty member who has undergone similar struggles to those of students makes a positive impact for students like her. For a faculty to have gone through the same struggles as a student such as having to work or take care of family members while in college, the faculty member is more likely to be understanding of student issues. This empathy can build a bridge for faculty to work with students to co-construct a reasonable plan rather than simply write off the student and not offer support. With an 
honest reflection about their experiences during their time taking classes, faculty can be vulnerable with students and share valuable lessons learned as a student.

Teena shared sentiments of vulnerability when she was asked how much control teachers should have in the classroom, she stated:

...just maybe keep the class running together or... maybe sharing their stories with the classroom other students can relate to. 'Cause I noticed some professors are like, they don't share their past or what they experienced based on education. And it's really important to hear how they got through, how they made it. So what were their challenges? "Cause then that it gives us insight of inspiration to keep going like "Hey you're not alone, we've all been through this." (Teena Interview, December 20, 2017)

Teena suggested sharing the struggles of being a student in the context of controlling the classroom and not in having shared power between students and faculty. Similar to Cheryl's response about reflection, Teena gave a suggestion around the topic of power (control) and how sharing stories of struggle should provide connection to students leading to empathy and understanding within faculty when working with students who are facing out-of-school issues. Furthermore, she suggested that students learn from the faculty member's experiences as a student. Digging deeper, Teena seemed to be looking to make a connection with the faculty member teaching her course as she looks to gain wisdom on being a student. The connection would provide inspiration and motivation as Teena would be able to see herself in the faculty member. Teena spoke about faculty having empathy towards students based on past experiences and struggles having been a 
student in the past, but also using their past experiences to connect with students. The calls for connection and learning from faculty's experiences as students were only brought up by Cheryl and Teena, although six of the eleven interviewees alluded to faculty reflecting on their experiences being a student as a means of understanding and empathy. This suggests that students possibly believe that understanding, empathy and connection to the faculty member are ways to break power relations.

Creating participatory opportunities for marginalized students through coconstruction

Student participation was a common theme mentioned in the interviews. Darryl, an African-American male in his 50's and formerly incarcerated student, accurately described what I was trying to do through co-construction when he was asked if he had a say in classroom policies:

We had an open door policy; that's a good important point...where (students) had input for determining, for instance, the way we graded...It made us realize that by us voting... I would say to an open door policy in terms of participation. That alone encouraged participation, realizing that you had some input how we do things, how we go about determining how to better educate ourselves. (Darryl Interview, December 18, 2017)

Darryl spoke of the environment that welcomes voices and opinions, where the faculty member encouraged or made space for students to determine the classroom policies and learning environment. Directly, he indicated that privileging student voice encourages participation. In his statements, he argued that voting on classroom policies was a 
precursor to active engagement and participation in everyday classroom activities such as working on problems or building with colleagues. According to Darryl, this participation was integral for making decisions about his own learning, putting power in his hands and motivating him to participate. Cheryl indicated the tone was set that collaboration and participation would be a regular part of the class (Interview, December 19, 2017). Voting on classroom policies at the beginning of the semester was a segue to participation in other parts of the class where learning occurred and would provide motivation for students.

Phuong described the transformative and motivating nature of using coconstruction, specifically the participatory aspect of it. When asked why is it important for students from Bistoun to be interviewed on this matter, she referred to her experiences being poor initially and later described the impact of co-construction generally speaking:

To have the power, to have the ability, I feel like it'll encourage people to go to school more. Because then like there's always the option: "Should I quit school and work full time or should I make school work?" It's hard to make school and a full-time job work. So if you felt like you had an input and you felt like you mattered and you weren't just a blank face, it would encourage people to go more. (Phuong Interview, December 19, 2017)

Phuong mentioned of the financial struggles students from low-income areas often face which put into question the utility of education in the short-run. Going to school does address the immediate needs to put food on the table or help pay next month's rent, 
something that many low-income students must deal with at home. With competing interests such as survival, Phuong indicated it is easy for students to turn away from pursuing an academic goal and go to work. Alternatively, she argued that coconstruction can give hope for completing higher education to students with out-ofclass responsibilities. The opportunity to provide input on their classroom was not the norm for the student interviewees yet it was memorable for them. Both Darryl's and Phuong's responses indicated an opportunity to participate which is motivating.

\section{Section 2: Co-constructing the classroom}

Analysis of teacher journals revealed extensive class time was designed to be co-constructed, at least from my perspective as the classroom teacher. This section will show four components of the classroom that were revealed in my analysis to be instrumental structures and activities through which to facilitate co-construction: classroom practices (norms), goal setting through MOU's, whole-class quizzes and projects.

\section{Developing classroom practices}

The semester began with community building (Teaching Journal, August 21, 2017). The purpose of building community was to set the tone for the semester that the classroom was a safe space for collaboration and questions could be asked. It has been my experience that many students of color have imposter syndrome and choose not to ask questions in fear of appearing stupid. The relationships built early in the semester 
hopefully would break those fears. After the syllabus was covered, students worked in groups to determine the grade weights (Teaching Journal, August 23, 2017). I provided bounds for each grading category while each group chose their preferred weights within those constraints. Below were the bounds provided:

- Quiz up to $10 \%$

- $\quad$ Homework up to $25 \%$

- Projects at least $15 \%$

- Exams:

- I exam: at least $30 \%$

- 2 exams: at least $35 \%$

- 3 exams: at least $40 \%$ (last exam replaces lower score of first two if applicable)

All the scores were put on the board and the most common choices were selected: $10 \%$ Quiz, 20\% homework, exams/final $40 \%$, projects $30 \%$. When asked about whether they felt they had a say in creating policies for the class, all interviewees mentioned the activity. During the remainder of the first week, I used class time to build community through several activities. The have-to/choose-to activity required students write goals with things they "have to" do and rewrite their goals using language they "choose to" do, sharing with their peers each time they write their goals. The purpose was for students to meet each other, define then share goals, and realize the power of words 
(Teaching Journal, August 21, 2017). Secondly, success quotes from various individuals were placed on posters around the room and students took a gallery walk visiting each poster taking notes. In groups, they created their own success quotes, read them out loud to the class and turned them in (Teaching Journal, August 23, 2017). This activity was for students to define their own success collaboratively with peers with a shared vocabulary around success as well as set the tone for success at the beginning of the term. Additionally, students designed phone apps to that would help them succeed in the course and present the components to the class (Teaching Journal, August, 23, 2017). The activity was designed for students to think about resources useful to them, creatively express them in the form of an app and use these resources during the semester such as tutoring, office hours or counseling.

The community building activities culminated in developing classroom practices that students and faculty all agreed to. They are similar to norms which are ideas and beliefs, but the term practice implies concrete action which is why I chose the term instead of norm (Teaching Journal, August 30, 2017). Of the 30 classroom practices, three main categories emerged: community (action), general study skills, and selfempowerment. Community (action) indicated a desire to work collaboratively with peers and support each other, thus the action component. Classroom practices that fell under this category possibly came about as a result of the community building activities just prior to the development of the list. Practices that fell under the general study skills 
category consisted of things like being prepared, get sleep, be on time and not falling behind. These are surface level recommendations and are important behaviors to do, but don't address deeper issues that low-income students of color may have. The general study skills category had the second highest number of practices. The most number of practices fell under self-empowerment such as being brave, believe you can improve, put yourself out there and feel like you belong. The self-empowerment practices spoke to symptoms of systemic issues such as imposter syndrome, not seeing one's self in curriculum or educators and low expectations of teachers to name a few.

An additional policy that was co-constructed was the weekly online homework due date and time (Teaching Journal, August 28, 2017). Typically when I am teaching, my default due date and time is the beginning of the subsequent class meeting from when content was last covered, which would be Monday at 8:00am each week for the course in the study. I believe a later due date and time may decrease the likelihood of procrastination beyond the day that we engage with newer material; the more students àttempt homework before class, the more likely they will see the connection between subsequent concepts. I suggested my default due date and time and put other options such as Friday, Sunday and Monday after class (Teaching Journal, August 28, 2017). The class voted for the homework to be due Monday after class to which I put several times: 10:00am, noon, 3:00pm and 8:00pm. Some students wanted homework be due at 
$11: 59 \mathrm{pm}$, but I put an upper bound of 8:00pm because I didn't want students to procrastinate too late after class. The students voted for 8:00pm.

These activities set the tone for the semester that students would collaborate with each other and with me (co-construction). My intention was for students to feel they had power. There was some evidence that student did indeed feel power in my classroom. When asked the question about giving students power, Juanita articulates:

Choosing or working through the syllabus and deciding how much the percentage (of different categories) and how much that works for students. I actually think that was like really good. And that set the tone for the rest of the class for the rest of the semester. That, ok, if something isn't working for us, if we come forward and say something, that you'd be open to that. (Juanita Interview, December 20, 2017)

Here, Juanita explained that voting on grading weights worked for students. She further emphasized that students had a voice and their perspectives were privileged as indicated by the ability speak up. Although she attributed power to the faculty member by giving space for students to speak, underneath her responses lie the transformative power of co-construction: students had agency to speak their minds. This would be the tone that she referred to, that students could participate in ways and make requests that worked for them.

Particularly true in mathematics classes, faculty create the course and set the tone for the semester which traditionally has excluded low-income students of color creating underrepresentation in STEM majors. In this study, building community 
promoted student perspectives and students built relationships with each other rather than expend energy resisting traditional power relations. The community building and co-construction of policies brought in and celebrated the lived experiences of the students by using their voice to drive the learning environment of the class and put some power in the hands of the students.

\section{Settings goals with MOU's}

The assignment was designed as a reflective assignment and to set goals for success in the semester. The Memorandum of Understanding (MOU) assignment was inspired by coursework in the EdD program where I co-constructed academic goals towards my proposal defense and dissertation with my professors while enrolled in courses. For full points, students checked-in with me about writing their MOU and also checked-in with me about the progress of their MOU (see Appendix E). Whether or not. the students met their goals, they still received full credit for meeting with me both times and writing a reflection. During the first round of check-ins, I discussed with students how useful and realistic their goals were, but also pushing them when I believed they were selling themselves short (Teaching Journal, November 15, 2017). I gave the same feedback to two students, suggesting a goal of explaining mathematics to be included in their MOU's. One student did not receive the suggestion well, feeling too much pressure to learn the mathematics (C. Robinson, MOU, December 11, 2017; Teaching Journal, December 4, 2017). The other student who took on the suggestion 
saw it as a leadership opportunity (R. Galicia, MOU, December 11, 2017). Both students, women of color, came into the semester with low math confidence, the assignment did not work for both students. The MOU was more transformative for one student and not the other. Table 2 below summarizes the MOU's for the focal students in the study.

Table 2: MOU Submission of Focal Students ${ }^{1}$

\begin{tabular}{|c|c|c|c|}
\hline $\begin{array}{l}\text { Focal } \\
\text { student }\end{array}$ & $\begin{array}{l}\text { Initial goal } \\
\text { submission }\end{array}$ & Reflection & Themes \\
\hline Teena & $\begin{array}{l}\text { Successful group } \\
\text { presentation; team up } \\
\text { with study group; } \\
\text { work on } \\
\text { communication with } \\
\text { staff in school to have } \\
\text { more access to } \\
\text { resources }\end{array}$ & $\begin{array}{l}\text { Previous presentation was } \\
\text { not successful because } \\
\text { group didn't understand, } \\
\text { couldn't meet with members } \\
\text { and filling in for others. Met } \\
\text { goal of MOU through } \\
\text { communication and sharing } \\
\text { documents. She checked in } \\
\text { on other members to support } \\
\text { others. }\end{array}$ & $\begin{array}{l}\text { Group } \\
\text { presentation. } \\
\text { Community. } \\
\text { Communication. }\end{array}$ \\
\hline Naydea & $\begin{array}{l}\text { Engage more in the } \\
\text { class, work harder to } \\
\text { understand the } \\
\text { material. Come to } \\
\text { class everyday. }\end{array}$ & $\begin{array}{l}\text { Going to tutoring only to get } \\
\text { HW done. MOU helped me } \\
\text { realize goals to get back on } \\
\text { track. Going to tutoring for } \\
\text { understanding. Engaged } \\
\text { more in class and asked } \\
\text { questions. }\end{array}$ & $\begin{array}{l}\text { Engage. Asking } \\
\text { questions. }\end{array}$ \\
\hline Darryl & $\begin{array}{l}\text { Connect information } \\
\text { from class to areas of } \\
\text { society. }\end{array}$ & $\begin{array}{l}\text { Guidelines set up (at the } \\
\text { beginning) was very helpful. } \\
\text { Guidelines allowed me to } \\
\text { focus on project and data. }\end{array}$ & $\begin{array}{l}\text { Connecting } \\
\text { math to real life. } \\
\text { Co-construction. }\end{array}$ \\
\hline
\end{tabular}

\footnotetext{
' Some students did not submit MOU's or follow-up reflections.
} 


\begin{tabular}{|c|c|c|c|}
\hline & & $\begin{array}{l}\text { Found purpose of how to } \\
\text { use data in society. }\end{array}$ & \\
\hline Cheryl & $\begin{array}{l}\text { Ask more questions. } \\
\text { Earn A. Learned } \\
\text { about support groups } \\
\text { and using tutoring. }\end{array}$ & $\begin{array}{l}\text { Was more engaged in class } \\
\text { and going to tutoring mid } \\
\text { semester. Takes full } \\
\text { responsibility for not doing } \\
\text { work in group project. } \\
\text { Working to be on time. } \\
\text { Community and connecting } \\
\text { with colleagues is } \\
\text { important. You get out what } \\
\text { you put in. Do more } \\
\text { affirmations. }\end{array}$ & $\begin{array}{l}\text { Engage. } \\
\text { Community. } \\
\text { Affirmations. }\end{array}$ \\
\hline Papi & $\begin{array}{l}\text { Obtain passing grade. } \\
\text { Do take home in math } \\
\text { lab and work with } \\
\text { people in class. Study } \\
\text { with groups in math } \\
\text { lab for exams. }\end{array}$ & $\begin{array}{l}\text { Wasn't taking advantage of } \\
\text { down time. Smoking weed, } \\
\text { not working out, going out } \\
\text { on Sunday when class was } \\
\text { Monday. }\end{array}$ & $\begin{array}{l}\text { Time } \\
\text { management; } \\
\text { prioritizing }\end{array}$ \\
\hline $2 \mathrm{~K}$ & No submission & No submission & \\
\hline Carrie & $\begin{array}{l}\text { Past last test. Ask for } \\
\text { help during class; too } \\
\text { proud to ask for help. }\end{array}$ & No submission & Asking for help \\
\hline Juanita & $\begin{array}{l}\text { Work well with group } \\
\text { and not hate each } \\
\text { other. Continue } \\
\text { communicating } \\
\text { despite frustration. } \\
\text { Group project to } \\
\text { decrease stress. }\end{array}$ & No submission & $\begin{array}{l}\text { Group } \\
\text { presentation. } \\
\text { Community }\end{array}$ \\
\hline Phuong & $\begin{array}{l}\text { Stay on top of online } \\
\text { homework and be } \\
\text { more proactive when } \\
\text { it comes to studying } \\
\text { for exams. Better }\end{array}$ & $\begin{array}{l}\text { Use phone and laptop for } \\
\text { reminders. Help others; } \\
\text { didn't want to because } \\
\text { didn't want to sound like a }\end{array}$ & $\begin{array}{l}\text { Leadership. } \\
\text { Time } \\
\text { management. }\end{array}$ \\
\hline
\end{tabular}




\begin{tabular}{|l|l|l|l|}
\hline & $\begin{array}{l}\text { time management and } \\
\text { force self to do work. }\end{array}$ & $\begin{array}{l}\text { smart ass. Learned how to } \\
\text { not sound like one. }\end{array}$ & \\
\hline Kim & $\begin{array}{l}\text { Master material for } \\
\text { exam. Gain more } \\
\text { confidence. Work } \\
\text { with group and work } \\
\text { with them in math } \\
\text { lab. }\end{array}$ & $\begin{array}{l}\text { Worked with group. } \\
\text { Worked with new people. } \\
\text { Thoughts students who } \\
\text { understood material would } \\
\text { just me negatively if I asked } \\
\text { for help. Not being afraid. }\end{array}$ & $\begin{array}{l}\text { Asking for help. } \\
\text { confin }\end{array}$ \\
\hline
\end{tabular}

Of the focal students, a few common themes emerged. Unsurprisingly, most students had goals of improved grades through time management and engaging more in and out of class, a common goal for any student. Another common theme was community whether working with peers to study for exams, understand material and complete homework or working successfully as a group for the final project. These themes possibly rose as a result of the community building at the beginning of the semester and the whole-class quizzes that promoted collaboration. My intention was to have a strong community of learners that collaborated with each other in and out of class. Another common theme that emerged was about students asking questions. Two women of color had a hard time asking questions. Carrie felt too proud to ask questions while Kim was fearful of being judged negatively for not knowing an answer. Both of their experiences point to deficit views of not knowing or seeking further understanding. It's possible their prior experiences in school, especially math classes, have been negative when they asked for clarification or were confused. The vulnerability and honest reflections were co-constructed. Although this was Kim's third class taken with me, it's possible that her 
reflection was less co-constructed. Yet, I pushed them to be sure they reflected about deeper areas of growth rather than surface goals.

During the second round of check-ins, students shared reasons why they did or didn't meet their goals in the MOU and I often pushed students to reflect deeper. Papi reflected that our second check-in helped him identify that he was choosing recreation over school which was ok, but that he would need to adjust his time commitments to be able to do both (Papi, MOU, December 11, 2017; Teaching Journal, December 7, 2017). He earned full points, but more importantly reflected on how he prioritized his time and commitments. The design of the MOU was for students to set goals and reflect on why their goals were met or not. Many of these meetings occurred during office hours as some students wanted more time to discuss their MOU's and progress (Teaching Journals, December 11, 2017). For one student, the MOU assignment was transformative.

Naydea explicitly shared how the MOU directly impacted her. In her reflection on how she met or didn't meet the goals of her MOU, she wrote

The MOU helped me realize and review my goals for this course and get back on track...I begin going to the math lab more to get tutoring so that I could better understand the material. Also, I engaged more in class and asked questions about the material as well. Now I feel confident in my completion of the course, and I feel good about understanding the material and not struggling or stressing during the (exam). (Naydea, MOU, December 8, 2017) 
She explained how the MOU assignment had a direct impact on her success in the course. The reflection sparked a desire to engage in and out of the classroom more than she previously had. In our follow up check-in, she was much more brief in her words and wrote much more in the reflection submission (Teaching Journal, December 11, 2017). The structure of the MOU was for reflection and it was helpful for Naydea to reflect resulting in higher engagement with the class.

The MOU assignment was designed to be co-constructed between students and faculty (see Appendix E). The check-in requirement resulted in deep conversations about students' goals and assisted students with reflection about the semester. Many of the MOU's were general in nature such as "pass the class" (Carrie, MOU, November $15,2017)$, but some were more specific about earning points by "going to success events" (S. Aadel, MOU, December 10, 2017). As students shared their goals and progress towards goals with me, I was able to ask why they were able to meet or not meet their goals and push their reflection further (Teaching Journal, December 4, 2017). This was be the co-constructed part of the MOU. Students were not punished or deducted points for not meeting their goals. Rather, they earned points through reflection whether they met their goals or not. The co-construction allowed me to support students and provide resources for students to meet their MOU's. Although there were deadlines and the faculty member assigned points, both indicative of 
traditional power relations, the collaborative process created a shared power between the students and faculty.

Most focal students met their goals written in their initial MOU's. Before submitting their follow-up reflection, students met with me during the second round of check-ins students where I asked them to share how they knew they met their goals and what they did to meet or not met their goals. Papi didn't seem to meet his goal, but instead discussed potentially why his goals weren't met. His vulnerability to share his decisions for hanging out with friends indicates a trust he had with me and is a step towards being himself in academic settings. Cheryl also indicated how she may have not been able to work towards her goal of earning an by by taking responsibility for not contributing to the group project, yet she shared the necessity of collaboration with peers. Cheryl and Papi's reflection about not meeting their MOU's indicated an authentic vulnerability in them possibly a result of the strong relationship I had with both students; it's possible that a distant relationship would not have yielded the same honest reflection.

\section{Collaborating through whole-class quizzes}

The building activities at the beginning of the term helped set the tone for the focal pedagogical strategy for learning mathematics. I used a quiz structure that encouraged collaboration within small groups and as a whole class (Teaching Journal, August 28, 2017). More than just a participation quiz, whole-class quizzes were a 
primary mechanism for student engagement and occurred frequently. All students who took the quiz earned full credit while students who missed class and communicated their absence earned half the points. In small groups, students worked on problems mostly based off of the homework and put their answers on the board. A large group discussion ensued following student work put on the board (Teaching Journal, September 27,2017$)$. The number of points earned was determined initially by the number of correct answers given and one score is given to the whole class rather than individual scores. This structure of community grade versus individual grade is nontraditional and promotes collaboration (Teaching Journal, August 28, 2017).

As the semester unfolded, the structure of point earning evolved. Points were earned by students explaining answers of other student work, wrong answers that elicited larger discussions, questions asked by students and debates about the content between students in addition to correct answers (Teaching Journal, October 16, 2017). The new structure to earn points motivated student participation. As I anticipated, whole-class quizzes became vehicles for co-constructing knowledge in the classroom. In one instance, a student worked on the board and other students provided assistance from their chairs (Teaching Journal, October 16, 2017). Facilitation of discussions amongst the whole class required constant questioning: I regularly said "I still don't get it, can someone provide a different explanation?" or asked "did someone get something else? How did you get that?" (Teaching Journal, September 6, 2017). There was an 
expectation of students to participate which replicates traditional power relations, yet co-construction could not exist without student participation.

A few weeks went by before I figured out which students were most likely to put answers on the board or participate first when asked to explain a result on the board (Teaching Journal, September 20, 2017). In an effort to elicit participation from more students, I walked around during the small group work and answered questions, but also looked to find students who were afraid of writing wrong answers on the board yet had correct answers (Teaching Journal, September 20, 2017). Less confident students put answers on the board after verifying it was correct (Teaching Journal, October 4, 2017). At times, a more confident student would make a mistake and correct their mistake after calling me over to help them. I asked them to put their incorrect answer on the board then asked for different results to be on the board (Teaching Journals, October 16, 2017). The differing answers on the board led to debates, especially if the wrong answer was a misconception that many other students made. The debates became rich discussions about content and student explanations across differing perspectives meant that knowledge would be co-constructed during the quizzes. Often, students were asking and answering each other's questions and I felt as if students were running the class (Data Memo Weeks 9-10, November 7, 2017). To facilitate discussions, I pointed to questions that were unanswered or highlighted responses that elicited deeper thought. 
Whole-class quizzes became a primary vehicle for co-constructing mathematical knowledge through small group work and large group discussions.

Students particularly found whole-class quizzes helpful and changed the way they thought about themselves as participants in co-constructing knowledge. When asked if giving power to students who struggle with mathematics would be helpful, Carrie responded:

That'd also be really great... each student come up and do a problem with the whole class...Basically give them more of a chance to participate, not like force them to...I feel if you do it or teachers do it every so often, students would be more willing to go up and help, do a problem on the board, do a lesson. (Carrie Interview, December 19, 2017)

Here, she attributed power to students working on the board working with their peers. She also spoke to the learning environment that would be created with this type of opportunity to participate, that students would have more of a desire to put their answers for the whole class to see. She mentions both co-constructing knowledge and the learning environment where students actively participated and engaged with mathematical content. I facilitated these activities in class by asking students to explain their answers including times when there were multiple solutions on the board (Teaching Journal, October 16, 2017).

In Phuong's response to what made her feel heard, she responded "usually I wouldn't (participate), but then when you, you'd be like 'hey what do you think this is' or 'can you write it up on the board?' It helped (me participate)." (Interview, December 
19, 2017). Phuong would eventually have the confidence to regularly share her work on the board including solutions reflecting common misconceptions. Her work on the board elicited questions and explanations from other students where they agreed and disagreed. These discussion were indications of knowledge co-construction because students and I were both contributing to the development of mathematical content in the classroom. In other instances where students worked through problems, they were asked to explain their reasoning and the class was often were split between the correct work and the work with common misconceptions (Teaching Journal, November 20, 2017). These interactions were prime examples of co-constructing knowledge between students and the faculty as multiple answers were put on the board, questions were asked and questions were answered.

Whole-class quizzes described in this study break traditional power relations in several ways. First, students are regularly sharing their mathematical work with the rest of the class which implies that their knowledge and knowledge creation is an important aspect of the class. Second, students providing mathematics explanations for their peer's work puts the power with the students as they are confirming each other's work as opposed to the faculty member confirming. Although I verified the correctness of work on the board, students were coming to similar conclusions and supporting each other's mathematical reasoning. Additionally, multiple answers were sometimes put on the board and students argued why they believed each of the answers were correct. This 
participation of mathematical explanation emboldens power within the students resulting in co-constructed mathematical knowledge. Traditionally, faculty are required to disperse knowledge. But in the case of whole-class quizzes in the study, student debates led to questioning and further mathematical discourse putting the power in the voices of students to disperse knowledge.

Figure 3 describes interactions between students during whole-class quizzes.

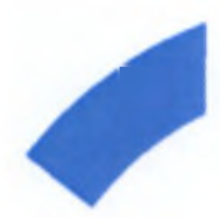

\section{Student} Facilitation

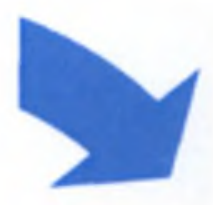

Student

Student

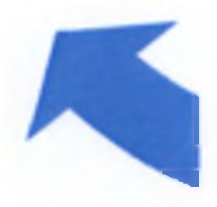

Faculty

Facilitation

Fig. 3

Knowledge was generated between students, sometimes facilitated by students and sometimes facilitated by me, as students worked together. 
In addition to the voices of students being highlighted for work, their actions spoke loudly as they became risk takers, willing to put wrong answers on the board for the sake of the whole class earning points. This is a major step for students of color who have low confidence with mathematics and are afraid of failure. Contrary to the banking model of education where the faculty member is assumed to have all the knowledge, the whole-class quizzes in this study highlight student knowledge, voice and participation.

\section{Section 3: Using Mathematics for Critical Perspectives}

In this section, I will describe the student work in the major projects of the class. This section will include the mathematics used to create arguments, social issues chosen to investigate and what outcomes, if any, came from the students' work. The two major projects of the course involved structured check-ins with me in order to receive full points (see Appendix $\mathrm{C}$ and $\mathrm{D}$ for prompts). At the beginning of each of the major projects, groups assigned different group members to various tasks and created a plan if a student did not complete their work. One of the tasks to complete was a statistical analyses and check-in with me. These check-ins were designed for students to coconstruct the mathematics of the project in addition to other components for both the written report and presentation. Although time was allotted during class for groups to work on projects, most of the check-ins occurred during office hours where students and I were able to make sure the mathematics was accurate and appropriate. Groups who worked with me in office hours were more likely to score full marks because I had 
worked with them to ensure accuracy and give feedback on how to earn all of the points.

\section{Lyrical Analysis Project}

This project was designed to educate students about the historical roots of hiphop and how it has been co-opted for financial gains for the elite. The full four part prompt is located in Appendix $\mathrm{C}$ and was assigned to students in the second week of classes with presentations three weeks later. In groups, students chose an album and tallied the number of references to six categories. While I assigned four categories promotion of money, demeaning women, encouraging use of drugs or alcohol, and promoting violence. Each group chose two more common themes to count that were prevalent in the album's lyrics. The tallies were entered into a spreadsheet and measures of center (mean, median, mode) as well as standard deviations were calculated. All groups created a histogram and pie chart using the data. These were the statistical analyses conducted for the project. With the data, students connected the album's message to a social issue, determining whether the album helped or hurt the problem. Groups completed a write up, presented their findings to the class (choosing the most compelling statistical analysis to support their argument) and another individual off campus. Additionally, groups met with me during office hours to co-construct the mathematics and determine the most compelling statistical analysis to support their 
argument. This project was conducted at the beginning of the semester so students primarily used measures of center and histograms or pie charts to make arguments. Topics of social issues were sexism, poverty, human trafficking and the intersection of racism and sexism. Two of the albums selected were by Kanye West and Future; both groups analyzing the albums chose sexism as the social issue because they counted a high number of references to the theme of demeaning women. In his album, Future has a line that says "grab that pussy like Donald" (Phuong, Lyrical Analysis, September 21, 2017). The recency of the reference combines political and social issues of today as Donald Trump is president and has been documented saying similar words. Both groups were critical of the uses of vulgar terms to describe women, that the artist "still teaches naive children to use those terms." (W. Ganci, K. Nguyen, V. Nguyen, P. O'Farrell, \& C. Van Digglen, Lyrical Analysis Project, September 21, 2017). These two groups chose histograms to portray the high frequency of references to demeaning women to argue that the albums' messages were contributing to sexism in society. Below are histograms used by the groups showing the number of references to demeaning women sorted by song. Figure 4 represents the Kanye West album and Figure 5 represents the Future album. 


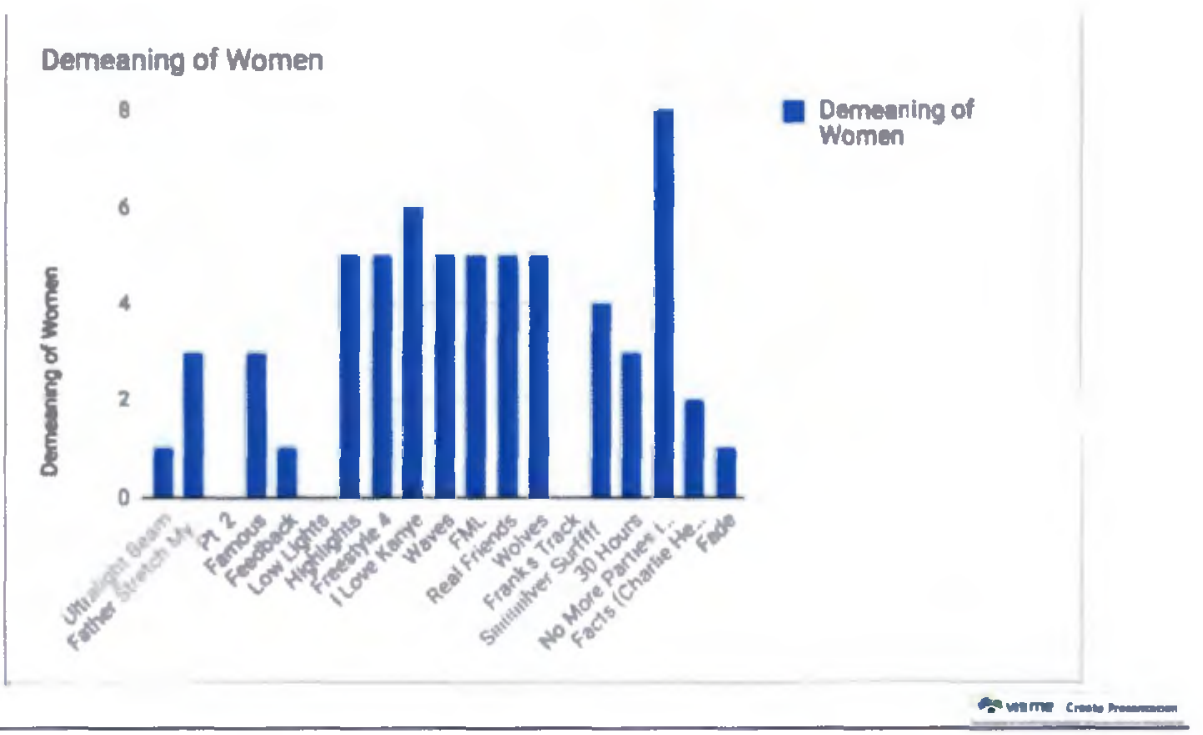

Fig. 4 Histogram showing counts of references to demeaning women in Kanye West's album

\section{DEMEANING WOMEN}

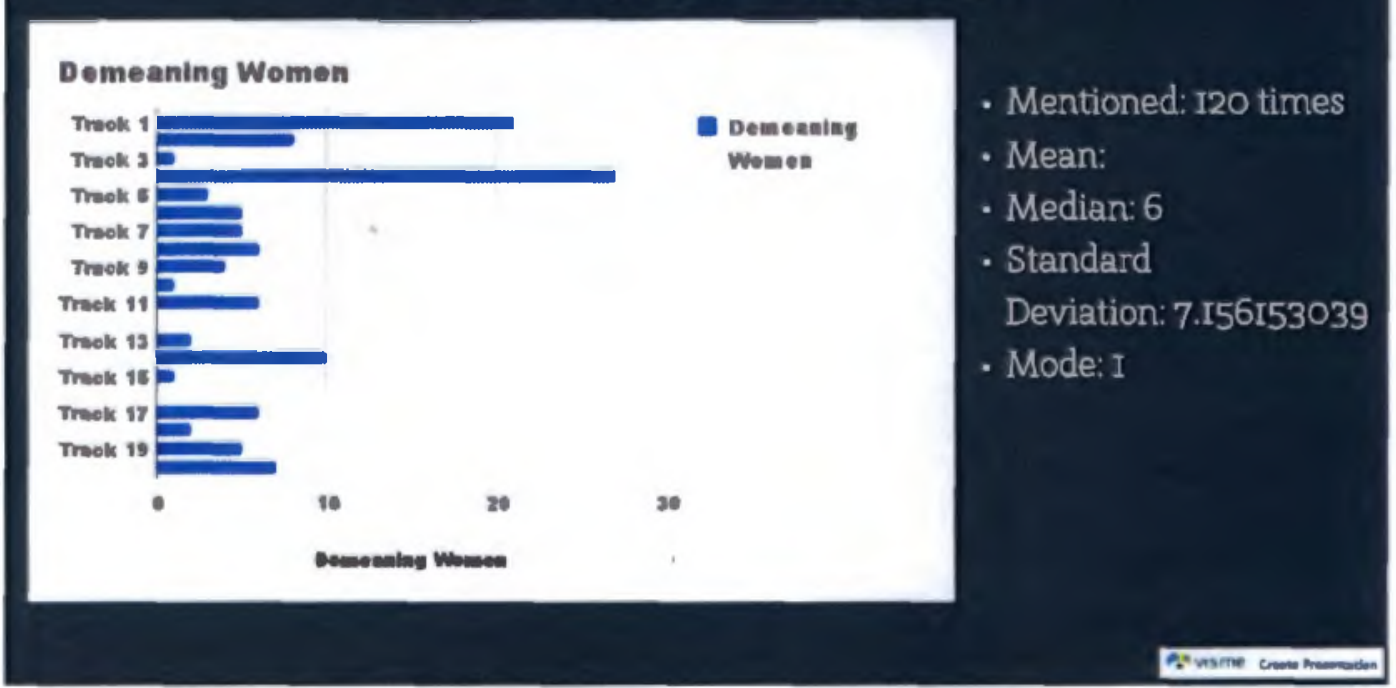

Fig. 5 Histogram showing counts of references to demeaning women in Future's album 
The two groups compared means of references to themes, noticing the highest means were demeaning women to argue that the albums making worse the problem of sexism in society. Here, the groups used statistical analyses of means and visual representations created by spreadsheets from data they gathered to generate an argument about how the albums exacerbate sexism.

Table 3 below summarizes the artist, group's chosen social issue, statistics used to create argument and whether the album helps or hurts the problem.

Table 3: Summary of Lyrical Analysis Projects

\begin{tabular}{|l|l|l|l|}
\hline Artist & Social Issue & Statistics used to argue & Help or hurt? \\
\hline Kendrick Lamar & Oppression & Histogram, pie chart. & Help \\
\hline Tupac Shakur & Poverty & Histogram, pie chart. & Help \\
\hline Kanye West & Sexism & Mean, histogram. & Hurt \\
\hline Too Short & Human Trafficking & Mean, histogram. & Hurt \\
\hline Vel the Wonder & $\begin{array}{l}\text { Intersection of racism } \\
\text { and sexism }\end{array}$ & Histogram. & Help \\
\hline Nas & Poverty and success & Pie chart & Help \\
\hline Future & Sexism & Histogram & Hurt \\
\hline
\end{tabular}

Students were able to use measures of center to argue that overall album messages either hurt or help the social issues they chose. In the case of the albums by Kanye West and Future, the higher number of references to demeaning women and specific content of lyrics meant that the albums potentially contributed to sexism. Other groups 
indicated that albums fight against oppressive structures through histograms and lyrical content. These show a use of mathematics to understand their worlds better through analyzing hip-hop albums.

\section{Participatory Action Research: Improving the college}

This was the final project for the semester and took the second half of the term to complete. The four part prompt is located in Appendix D. In this project, groups of students picked an educational issue and created surveys to administer to students. Questions were quantitative and qualitative in nature and were co-constructed with me. Qualitative responses were categorized, tallied and measures of center statistical analyses were conducted as well as generating a pie chart and histogram. Students generated a confidence interval and conducted a hypothesis test on specific data, appropriate to creating an argument for change. With all of the data and statistics, group chose the most compelling statistical analyses that argued the need for change at the college. Following, groups created or researched existing solutions at another college to the issue they investigated and presented their findings to the class. Each group was assigned to share their presentation a specific administrator or campus leader who would find the research project useful; I assigned the individual to share the information with based on my knowledge of the campus and which individuals were working on specific projects. Table 4 below summarizes all of the projects with educational issue, statistics used to create argument and proposal topic. 
Table 4: Summary of Participatory Action Research Projects

\begin{tabular}{|l|l|l|}
\hline Educational Issue & $\begin{array}{l}\text { Statistics used for } \\
\text { argument }\end{array}$ & Proposal topic \\
\hline $\begin{array}{l}\text { Connection to } \\
\text { campus }\end{array}$ & Hypothesis Test & $\begin{array}{l}\text { Extra credit and food at campus } \\
\text { events }\end{array}$ \\
\hline $\begin{array}{l}\text { (Awareness) } \\
\text { Resources for } \\
\text { studecumented }\end{array}$ & $\begin{array}{l}\text { Measures of center, } \\
\text { binomial probability }\end{array}$ & $\begin{array}{l}\text { Training for faculty, staff and } \\
\text { students }\end{array}$ \\
\hline EOPS counseling & $\begin{array}{l}\text { Mean, confidence } \\
\text { intervals, hypothesis } \\
\text { test }\end{array}$ & Peer mentoring \\
\hline Remediation & $\begin{array}{l}\text { Measures of center, } \\
\text { hypothesis test }\end{array}$ & Self-placement, co-requisites \\
\hline Tutoring & Measures of center & Increased number of tutors \\
\hline Housing & Pie Chart & $\begin{array}{l}\text { Partner with housing non-profit } \\
\text { organizations, dorms }\end{array}$ \\
\hline
\end{tabular}

Phuong's group decided to look at the problem of remediation. They asked students how many remedial classes (in math and English) taken, asked about feeling discouraged taking remedial courses and what suggestions the college should undertake to remedy the remediation problem (Phuong, Final project, December 11, 2017). The group conducted a hypothesis test to test the claim that more than the majority of students feel discouraged by taking remedial coursework; the data suggests that there was sufficient evidence to support the claim. They conducted a confidence interval to determine the mean number of remedial classes students took at COI and were $90 \%$ confident that the mean number of remedial courses students took was between 1.03 
and 1.59 courses; this is a low number considering the levels below transfer in both Math and English (four each). These statistical analyses were co-constructed as students and I worked on the analyses during the time allotted in class to work on projects (Teaching Journal, November 8,2017 ). The analysis provided evidence to argue for change at COI. They suggested the use of a self-placement tool like at another college in the state while expanding the number of co-requisite courses. The course in this study was the only co-requisite course at the college at the time. Additionally, the college began to develop a self-placement tool and used the recommendations of the students to initially build the tool. The participatory action research Phuong's group conducted had immediate impact in providing changes to the campus.

Juanita's group investigated awareness of resources for undocumented students. They used measures of center, proportions and binomial probability to determine how aware students were knowledgeable of how to help undocumented students. They found that while " $61 \%$ of students are aware of the termination policies...for undocumented students,...only $19 \%$ of (COI) students are familiar with resources that are offered on campus for undocumented students" and there was an " $89 \%$ chance that more than 6 out of 10 students at COI (were not) aware of resources on campus for undocumented students"(Juanita, Final Project, December 11, 2017). They used statistical analyses to indicate the lack of knowledge about how students can help their fellow undocumented colleagues. The statistical analyses, presentation and proposals were co-constructed 
both in class and out of class (Teaching Journal, November 27, 2017). This project was timely as the campus had recently offered an Undocually training for faculty, staff and students, something that the group proposed as a solution. Juanita and her group shared the results of the project with the administrator who brought the training to the college.

While not all project proposals made an impact on the college, all groups used mathematics to argue for change at their college. Because the final project occurred towards the end of the semester, students had more tools to work with than the lyrical analysis project. Although I gave sample ideas for research, some group possibly chose more surface level topics or spent less time co-constructing the mathematics, presentation or write up with me that led to less impactful projects. The co-constructing process allowed for both a combination of mathematical accuracy and connecting to critical consciousness if student proposals weren't addressing the issue (Teaching Journal, December 4, 2017). Across all projects, students were required to conduct a hypothesis test, construct a confidence interval, find binomial probability, analyze data using measures of center and create visual representations of data (see Appendix D). In these projects, students connected mathematics with social issues whether issues of sexism, poverty or education. In particular, students co-constructed which of the statistical analyses were appropriate to strengthen their argument for change whether a hypothesis test, confidence interval or measure of center. Students already had some understanding of social inequities, but this project allowed them to use 
mathematics to understand education better and make recommendations for change. This is of particular importance as much of mathematics is seen as abstract and not applicable to everyday life outside of engineering and business. For low-income students of color, these types of projects connect mathematics to the real problems they face and provide contexts to motivate learning mathematics (Frankenstein, 1980).

\section{Conclusion}

Using student voice is essential in co-construction and the students' perspectives indicate that faculty do have power in general, should reflect on their prior experiences as students and create opportunities for students to participate. Because low-income students have been taught compliance, they automatically give faculty power in the classroom and the faculty member has a responsibility to use that power to help the students with the most needs. This is done through faculty reflecting on their own experiences as a student to replicate positive interactions and classrooms which are essential to creating spaces and structures for participation in the classroom. These spaces, structures and opportunities for participation can occur in the ways that this study investigated: developing classroom practices, setting goals with MOU's, collaborating through whole-class quizzes and producing mathematical knowledge. Building community at the beginning of the semester including co-constructing classroom practices set the tone for the class that much of the semester would be coconstructed and engagingly participatory. Students were able to set their own agendas 
through the co-constructed MOU assignment and were not punished for not meeting their goals. The most frequent vehicle for participation in everyday classrooms was whole-class quizzes where students were running the discussion and co-constructing mathematical knowledge. With projects, students were prompted to co-construct mathematics resulting in office hours also being a place for participatory opportunities. An additional space for participation was co-constructing the final exam which put power in the hands of students. Through projects, students connected mathematics with social issues, exhibiting knowledge of critical consciousness through using mathematics to argue how a hip-hop album helps or hurts a social issue or argue for change at their college. The use of mathematics in these projects indicated a mathematical power wielded by students to critique social inequities and improve their educational settings. These classroom activities are particularly important for low-income students of color who have traditionally been taught compliance and direction following (Anyon, 1980). Traditional power relations that exist in schools have excluded low-income students of color from pursuing higher education which is exponentially more exclusive in mathematics. These pedagogical strategies of co-construction can break down power relations in the classroom by giving power to students, highlighting their existing knowledge and abilities to generate new knowledge. As a result, students will have more access to participating with classroom activities and be more motivated to pursue their education; these are particularly important in community college mathematics 
classes because the institutions are open access and there is a major underrepresentation of low-income students of color in STEM with math being the gatekeeper. 


\section{Chapter Five: Discussion and Implications}

\section{Introduction}

This study was situated in a community college mathematics classroom. Recent studies suggest that traditional pedagogies are less effective for students, but many community college math classrooms are taught in traditional manners (Cox, 2015;

Grubb, 2010). Unlike the studies of Frankenstein (1990), Gutstein (2016) or Brantlinger (2013), this study did not focus on the mathematics toward developing critical consciousness or using mathematics to critically view the world. Although there were components of using mathematics to read and write the world, this study looked to challenge the politics of knowledge by breaking traditional power relations between students and faculty (Frankenstein \& Powell, 1989). Because mathematics has been traditionally marginalizing for low-income students of color, there is a strong need to investigate ways to create access for learning mathematics (Spencer \& Hand, 2015). Co-construction is a manner in which students have more access to mathematical learning (Chen, 2016). The focus of the research was to investigate power relations and how they were impacted by co-constructing classroom policies, learning environment and knowledge. In this chapter, I discuss the implications of the findings in chapter four. In particular, I will argue for a need to use co-construction with low-income students of color. First, I will connect the findings to literature and lead into implications for practice including classroom and leadership recommendations. I will 
follow with my own reflection as a scholar-practitioner as I conducted practitioner research being a community college mathematics faculty with little to no coursework on education prior to beginning the EdD program.

\section{Discussion of findings}

\section{Section 1: Privileging student voice}

In this section, privileging student voice will have three subsections: believing faculty have power, practicing reflection and vulnerability and creating participatory opportunities for marginalized students through co-construction.

One of the major findings was students believe faculty have power in the classroom. This is possibly a symptom of the schools the students interviewees came from where teachers had all of the power to run the class, teaching students the curriculum of following directions and compliance (Anyon, 1980). It is possible that this trend continued into their community college careers (Grubb, 2010). Student interviewees indicated that many of the activities in the class were initiated by the faculty member from co-constructing grade weights to agendas for the class meeting to dates for exams and projects. These findings are directly aligned with Foucault's (2012) definition of power: in classroom settings, the faculty member has the power to create all components of the class without consultation of students. With power being afforded to faculty in many ways, I argue that faculty have the responsibility to use their authority for equitable outcomes and breaking traditional power relations in the 
classroom that disadvantage low-income students of color. One way to do this is to coconstruct components of the classroom like an exam (Ahn \& Class, 2011).

In their interviews, some students felt that faculty unfairly required unnecessary work. Papi indicated that he saw this as a form of punishment and resulted in less positive experiences for students. These experiences create a separation between students and faculty and discourages participation; resistance becomes co-constructed (Heyd-Metzuyanim, 2013; Hand, 2010). This is possible a result of most community college faculty seeing their students through deficit lenses or underestimate their students as indicated by Naydea and it is very possible that faculty will not give students opportunities to co-construct a class (Acevedo-Gil et al., 2015; Mesa, 2012). On the other hand, faculty must realize that they have the power to impact students' attitudes about learning math (Zavala, 2016). Giving students the power impact classroom policies and learning environment puts the student at the center of the learning process and validates their prior experiences.

Practicing reflection and vulnerability was another theme to emerge from student interviews. Emdin (2016) had acculturated himself to the culture of schooling which led him to not know how to teach students from the 'hood even though he identified as from the 'hood. It seems that faculty are required to uphold the merit and rigor of academia which results in merit based arguments. Meritocracy is a way that schools train students to acclimate to a white-middle class norm. The acculturation of 
faculty, whether to academia or middle-class lifestyle, poses a major problem for meeting the students' requests. Emdin's reflection about the education system is a starting point for educators to see how they might be perpetuating systems of oppression.

Students said faculty should remember what it was like to be a student and share it. One student, Teena, described the necessity of self-disclosure. Cordell (2017) suggests that professors should self-disclose their stories as a means of humanizing themselves, a strategy that doesn't directly help students toward content learning; faculty self-disclosure isn't a pedagogical tool that is enacted with students or is necessarily a means of engaging with material. Instead, self-disclosure builds relationships and is a humanizing way for faculty to work with students in the classroom, building-trust and validation of student experience (Roache \& Lewis, 2011). Research does support the need for students to connect with their faculty, particularly low-income students of color (Ladson-Billings, 1995). There is a major assumption here: the faculty come from similar struggles as the students in the class. The tension lies in how the existing education system has stacked the deck against low-income students of color that there are many more graduates of affluent and white backgrounds. It is highly possible that faculty growing up in middle-class suburban areas did not have to face the similar struggles that working class community college students face. Middle-class and more affluent students often don't have to work, have reduced family 
responsibilities and have cultural and social capital for navigating educational spaces, particularly higher education (Bourdieu, 1977). For an affluent student turned faculty member to recall what it was like to be a student will unlikely reflect similar struggles to those of low-income students of color.

The teaching journals regularly reflected students coming in during normal office hours, appointments made or randomly stopping by my office to chat about life. I saw office hours as a place for me to learn about my students more and connect with them to help address non-academic needs. The discussions about life were indicative of a mentorship where students confided in me about academic and out-of-school issues. I strive to what Duncan-Andrade (2007) refers to as a rida where faculty are mentors to students and provide much more than content learning. This pedagogy aligns with Teena's desire for connection and mentorship. She wanted to hear about the stories of faculty when they were students as a means to learn from them. The findings are validating for me as a faculty member who identifies with the student interviewees. It's very possible that the students still gave favorable responses despite interviews occuring after the grades were submitted.

Another emergent theme from student interviews was creating participatory opportunities through co-construction. Most commonly, student interviewees referred to voting on the percentages of weighting of grade categories although I looked to coconstruct knowledge, the learning environment and other classroom policies. This is 
part of what Freire (1970) argues is necessary for breaking the traditional teacher-asexpert pedagogical practices in the banking model of education. Students indicated the class welcomed feedback and ideas from students which encouraged participation in coconstructing classroom policies or doing problems to co-construct math knowledge (Langer-Osuna, 2007). Student participation is necessary in co-construction and thus I created structures and activities for co-construction to occur regularly (Ahlquist, 1991; Evans et al., 2006). Darryl indicated that co-constructing policies invited students to participate in other components of the class (Russo, 2015). I was hoping that coconstruction would create opportunities for students to participate who normally wouldn't participate, something that was affirmed by Carrie and Juanita (Chen, 2016; Clarke, 2004; Langer-Osuna, 2007; Mueller, 2009; Russo, 2015). Phuong and Juanita referred to how co-construction can make a student want to come to class more, that one's voice matters. Using the voices of students celebrates their lives, values their knowledge and builds on their strengths.

Bartolome (1994) argued the need for using the lived experiences of students as part of the classroom milieu. The use of co-construction gives a platform for students to actively participate without them compromising their values or who they are; instead, co-construction celebrates their lived experiences by giving students power to impact what occurs in the classroom. The decisions made by students are influenced by their prior experiences and come to the surface when asked to co-construct the class. 
Students impacted the policies, knowledge and learning environment through coconstruction and are able to bring their lived experiences into the classroom through their voice (Gutierrez, 2018).

\section{Section 2: Co-constructing the classroom}

Co-construction presumes and focuses on student strengths, something needed to help students of color in community college mathematics courses (Acevedo-Gil et al, 2015). The belief that students have strengths is a primary part of my pedagogy and has driven the co-construction of my classrooms. It seems that this view is a prerequisite for teachers who need to trust students to generate ideas, something needed in math classes (Zavala, 2016). In this study, co-construction occurred through intentionally planned activities, assignments and structures.

The beginning-of-semester community building activities were designed to set a collaborative tone for the semester. As students co-constructed grade weights, policies, success quotes, and classroom practices, they built relationships that would be instrumental for them to lean on and support each other. My intention was for students to have ownership over policies and rules with the expectation that ownership over these would give more agency to students. This is an example of what Salazar (2013) calls for co-creating the classroom with students that includes students' voices and will be representative of their needs, particularly on how to improve educational 
experiences. The use of co-construction is humanizing for students and is particularly important for marginalized students.

Community building has been indicated as a useful tool leading to coconstructing mathematical knowledge (Mueller, 2009). This is particularly important in the study because students played a major role in the everyday activities of the classroom. Working mostly collaboratively, the tone needed to be set early about how the class would be run. Through projects and whole-class quizzes, students regularly worked together in and out of class.

MOU's were designed for students to create their own goals in a math classroom. Similar to co-constructing policies and classroom practices, the expectation of the assignment was to build agency within students for the second half of the semester. Student-centered activities like the MOU have been found to be successful in other community college math classrooms (Cox, 2015).

Although the assignment didn't explicitly focus on mathematics, students still found motivation from the reflection process. Naydea indicated how she became more aware of what she needed to do and acted upon her awareness. The assignment worked exactly how I hoped with Naydea as the reflection created a spark, moving her to ask questions and work with colleagues, something Jaime Escalante calls ganas (Meek, 1989). With the lack of connection to the lives of students of color and low representation of faculty of color, traditional teaching methods are not be equitable for 
students of color (Ladson-Billings, 1995; Tate, 2004). This nature of mathematics requires a need to provide motivation for learning math for students of color.

Whole-class quizzes were a regular occurrence in the study. Happening almost everyday functioning similar to participation points, whole-class quizzes were the primary way that co-construction occurred throughout the term. Whole-class quizzes were primary vehicles for co-constructing mathematical knowledge. Because coconstruction of knowledge was a constant negotiation, it evolved over time (Chen, 2016; Lampert, 1990; Yackel \& Cobb, 1996; Yackel, Rasmussen \& King, 2000). Whole-class quizzes were collaborative structures that created increased access to mathematical content (Gresalfi et al., 2009). The low stakes tasks made the activities more accessible for students while deep discussions about mathematics made the activities rich. Students exhibited social norms during whole-class quizzes: explaining reasoning, explaining others' reasoning, offering counterexamples, questioning and attempting to make sense of others' reasoning are forms of norms typical to mathematics classrooms (Lampert, 1990). However, students in the study also exhibited sociomathematical norms, those norms particular to the practice of doing mathematics such as understanding what constitutes as an acceptable mathematical explanation (Yackel \& Cobb, 1996; Yackel, et al., 2000). The constitution of this understanding, including mathematical difference, is constantly being co-constructed between students and teacher. The norms evolved over time through the point system of whole-class 
quizzes. Initially, points were earned for correct answers; as the weeks passed, points were earned for multiple answers for the same problem, wrong answers, explanations of one's work, explanations of others' work, questions, answering questions and debates. These norms presume that students are holders of knowledge and can generate their own ideas about mathematics. Rather than following procedure, students made their own meaningful ways of solving problems, focusing on the mathematics and not status. This worked to create high participation in the classroom and co-construction of mathematical knowledge, pointing towards students developing positive identities learning mathematics (Boaler \& Greeno, 2000).

Because students led most of the discussions outside of lecture, they were afforded the power in the classroom challenging traditional politics of who held knowledge; instead of the faculty being the expert in the content, students were seen as experts because they were generating mathematical ideas and explanations to questions (Cox, 2015; Frankenstein \& Powell, 1989). Similar to Langer-Osuna's (2007) study, coconstruction of knowledge was intentionally used to develop agency within students. The structure of whole-class quizzes share features with complex instruction, which is a pedagogy ultimately about supporting all students to feel competent (Boaler, 2002). However, this study was not intended to take up complex instruction in higher education. 


\section{Section 3: Using mathematics for critical perspectives through projects}

With the projects, students investigated social issues through looking at hip-hop albums and creating research projects around improving the campus. One of the goals of the projects was to connect statistical content to the lives of students. These were similar in nature to the work of students in Gutstein's (2016) study and the math problems in Frankenstein's (1990) study. Similar to Gustein's (2016) and Brantlinger's (2013) studies, students used mathematics to investigate social issues such as education. Students shared their findings with leaders on campus in hopes that the research would lead to action. Math connecting to students' lives and faculty accessibility are two components that have been shown to work to promote learning in community college mathematics courses (Quist, 2015). On a deeper level, the project led to co-constructed mathematical knowledge around using mathematics to construct an argument and connecting the argument to a social issue. This is similar to what occurred in Gustein's (2016) study where he cocreated curriculum in a classroom community focusing on integrating mathematics and sociopolitical contexts.

\section{Leadership implications}

Individual change impacts small groups of students whereas larger scale transformation impacts whole institutions and systems. Because community colleges serve many low-income students of color, leadership is needed to transform mathematics classrooms for equitable change. I was put into a leadership position at a 
former college running the First Year Experience (FYE) program. I spent time focusing on building a strong team through reciuitment and community building amongst the members. I also focused on instructional cohesion through building community in the classroom and creating major assignments that crossed several courses. Over the course of my years at the former college, I made enemies who would prevent me from earning a permanent position. From these experiences, I learned the valuable lesson of communication. My prior experiences have created an edge in me where I'm hyperaware of relationships and the potential of how enemies can block any work I am trying to move forward; this edge is heightened in a district that has known to be contentious such as FCCD where I currently work. It's highly possible that I don't take as many risks because of the bridges that were burned, but these prior experiences have shaped how I interact with my current institution.

My own leadership positionality comes as a result of Herr and Anderson (2014) who argue that practitioner research is a political process because of the critical perspectives that can come from this type of research. Thus, I must also address my positionality within the institution. Institutional micropolitics are defined as negotiations over resources, ideologies and vested interests around issues ranging from tracking to jealousy, from how to teach to who teaches in which room (Herr \& Anderson, 2014). At my institution, I have taken time to build relationships during my first few years, which is low effort for me as an extrovert: I have intentionally spent time building 
relationships with counselors, like-minded social justice faculty, math faculty and administrators, taking them out to lunch or happy hour. I also used these interpersonal skills building with the math department who I would work with the most. These relationships built bridges for collaboration and a healthy feedback loop even if there are ideological differences, something I could not navigate at either of the prior colleges where I was an adjunct faculty member. Furthermore, full-time faculty members are seen in a more positive light around contributing to the institution which has privileged me with seats at various tables with the President, Vice President and Dean that oversees my department. Some of these privileges include math department chair, being the math lead on the Basic Skills \& Student Outcomes Transformation Grant to where currently half of my teaching load is paid and working with an upcoming large scale change called guided pathways (Bailey, Jaggers, \& Jenkins, 2015).

\section{How study informs practice of Community College math classrooms}

This research study moves educators towards a pedagogy of co-construction. I intentionally looked to build on the students' critical consciousness, yet the study focused on power in the classroom. The findings suggest that other community college mathematics faculty can use co-construction as an enhancement to their class. It is possible that the political nature of developing critical consciousness is too radical, too risky or requires long term reflection for faculty to implement change in their classroom. Co-construction, on the other hand, does not explicitly address political 
topics and may be more palatable for the general community college math faculty than a focus on developing critical consciousness as most faculty tend to be neutral and ambivalent (Duncan-Andrade, 2007). Using co-construction is a subtle way of challenging the politics of knowledge and mathematical knowledge where traditional education puts all the emphasis on the faculty member as the content expert; with student voice at the forefront of creating classroom policies, learning environment and knowledge, co-construction addresses major goals of critical math education of understanding the politics of math knowledge and knowledge in general (Frankenstein \& Powell, 1989). As a result, faculty can implement co-construction in their classrooms without changing the curriculum. However, I argue that it is necessary to challenge the existing mathematics curriculum designed to support the military industrial complex (Tate, 2004). Faculty can co-construct many parts of their classroom and here are a few:

- Grade weights

- Classroom policies like late homework, absences and dates (exams, projects)

- Exams by having students choose a subset of problems word-for-word to be covered on the exam

- Daily agendas

- Learning environment through building community, creating classroom practices/norms (for students and faculty), or potlucks. 
- Knowledge via small group work, whole class quizzes, student work on the board, gallery walks of student work, choosing texts, and determining prompts to respond to.

- Knowledge via group projects or other assignments during office hours Professional Development in Community Colleges

Necessary mechanisms and structures must be in place for faculty to take on pedagogical change. Research suggests that one-and-done trainings are not sustainable for long-term instructional transformation and faculty can quickly revert back to traditional teaching methods. Here are several structures that have been shown to work in higher education.

Research strongly suggest that communities of practice are sustainable ways for professional change, particularly in the classroom which is where I believe change must occur. One-and-done trainings, or one-time trainings/workshops, can only affect change for a short period of time; more sustainable change happens through continuous, ongoing dialogue on improving classroom structures (Isern, Orme, Rasmussen, Reid, \& Roe, 2015; Parker, Morrell, Morrell, \& Chang, 2015). Collectively, faculty should develop communities of practice where they work collaboratively with other faculty over an extended period of time to improve their classroom instruction while paying part-time faculty (Bourque, 2016; Gonzalez, 2009; Liu, Miller, \& Jahng, 2016; SidmanTaveau \& Hoffman, 2018).Within these communities of practice, faculty can look 
deeply into their practices: reading articles, implementing co-construction, visiting classrooms and having critical conversations around structures of education and the nature of traditional mathematics. These communities of practice should use critical mathematics frameworks described by Frankenstein and Powell (1989), Gustein (2016) and Gutierrez (2018). Although the list provided is not exhaustive, it is a starting point for groups of faculty looking to change their classrooms for socially just purposes. With the collaboration of full-time and part-time faculty, communities of practice can provide structures for long-term, sustainable change in faculty practice.

Although there are conferences for community college math faculty to attend, often the conferences does not address issues of social justice or will have a small percent of workshops addressing social justice and equity. Still, these spaces are important to connect with colleagues who are interested and have been doing work that serves the most underserved but do not have the language of social justice and equity. On the other hand, there are social justice specific conferences like Teachers 4 Social Justice which is a general conference on social justice, but there are math focused ones such as Creating Balance in an Unjust World. These social justice focused conferences are focus on K-12 classrooms and small in quantity yet are rich in quality as the community of social justice oriented math educators. These healthy spaces are good places to build with like-minded educators across the country. Through these 
conferences, faculty can meet potential colleagues to bring to their departments as trainers, consultants or to teach courses.

\section{Transformative Leadership}

In his book about leadership, Fullan (2001) provides a framework for individuals leading in a culture of change. There are many different leadership frameworks, yet this one speaks to me as they focus on qualities I believe to be essential in leadership. He argues through understanding the change process and relationships, leaders can build knowledge coherence which is necessary for instructional change. Relationships provide opportunities for collaboration and avenues for critical feedback that becomes constructive instead of combative. With these collaborative opportunities, leaders can create knowledge coherence for change - this will be particularly important for sustainable change of community college mathematics faculty to transform their classrooms that traditionally replicate power relations to ones where faculty and lowincome students of color co-construct the classroom. As leaders will face resistance for any change and encounter implementation dips, Fullan (2001) must warns that no majòr transformation occurs quickly and to be slow and steady with the change. He emphasizes that all this change must occur with a foundation of moral purpose, one that focuses on the greater good of society. Scholars further this moral purpose argument to more specific concepts such as social justice (Shields, 2010; Stanback-Stroud, 2009; 
Theoharis, 2007). This change I am suggesting is a focus on equity to help students of color.

When I stepped into the department chair role in Fall 2015, the department had very low participation. Almost three years later, the department has many avenues for participation and the faculty have stepped up to work together on several fronts with half of the department participating in some group. There are communities of practice around content specific topics, such as statistics, as well as improving student engagement and affective domain. I have shared the research from this study in the student engagement community of practice because the goal of the group is to increase student engagement in the classroom and co-construction is a reasonable way to do so. The student engagement group encompasses many different mathematics courses and involves multiple classroom visits and idea sharing in meetings. The statistics group creates or finds activities to deepen student understanding through small group work and student presentations. The affective domain group meets to learn and implement strategies to improve student self-perception with mathematics. Moving forward, there will be more content specific communities of practice around a combined algebra course as well as trigonometry and pre-calculus and all communities of practice will investigate co-construction of classroom policies and knowledge generation. Also, I will use research articles in these communities of practice for readings to develop common 
language. I have also used the evaluation process as a means of promoting the growth of teachers rather than just an administrative task to be completed.

Also moving forward, I plan to use existing administrative procedures to transform classrooms. First, I will use the Student Learning Outcomes (SLO) cycle to improve classroom learning, creating formative assessments co-constructed with students that engage students and will be helpful for faculty to improve their instruction. Through these structures for growth - communities of practice, evaluations and SLO's - I will work directly with faculty to transform their classrooms for equitable outcomes. I will use my interpersonal skills to develop relationships and provide critical feedback, but also support where faculty feel most vulnerable. Co-constructing a course doesn't directly require faculty to investigate their racial biases, but does challenge the notion that faculty are the only holders of knowledge. With the structures of communities of practice, evaluation and SLO's, I will work with faculty to develop classroom activities to include the voices of students and engage students beyond passive learning. Although any given activity is carried out in one class session, I expect that faculty will see how students engage when power is put into students' hands, and become excited that their students will become active participants in their classes. Second, I have used and will continue use evaluations to transform classrooms. With evaluations, I worked with faculty to try something new to engage students - particularly co-construction - and the engagement of students in addition to use of innovative practices would result in a 
higher evaluation score. This change will be slow and there will be implementation dips in the process so I am expecting larger departmental change to occur over a few years. While the needle slowly moves of transforming COI's math departmental classrooms, I will work with a statewide professional development organization in their equity department.

The California Community College Success Network (3CSN) is an organization of community college professionals providing growth, learning and development opportunities for community colleges across the state. They have leadership trainings, but also equity trainings. Although the equity conversations revolve primarily around traditional success measures such as closing the achievement gap, the conversations around race, class, gender and sexual orientation are non-existent outside of the equity discussions. I will join the $3 \mathrm{CSN}$ team to increase the reach of transforming classrooms to improve experiences for low-income students of color by working with faculty to use co-construction. As the state moves towards implementing guided pathways and shorter sequences to graduation, equity comes to the forefront as colleges will look to increase outcomes for students of color. $3 \mathrm{CSN}$ is one of the bodies being tasked with providing support for community colleges across the state. I will use the research from this study, my knowledge of communities of practice, evaluations and SLO process to share with colleagues at other colleges to transform their classrooms. The process will require leadership on my part to build with colleagues that I will work with in a short period of 
time. Table 5 below is a modified logic model of next steps including inputs, stakeholders, outputs (activities) and goals.

Table 5: Logic Model of Next Steps

\begin{tabular}{|c|c|c|c|c|c|}
\hline Inputs & $\begin{array}{l}\text { Stake- } \\
\text { holders }\end{array}$ & Outputs & $\begin{array}{l}\text { Short-Term } \\
\text { goals }\end{array}$ & $\begin{array}{l}\text { Mid-Term } \\
\text { goals }\end{array}$ & $\begin{array}{l}\text { Long-Term } \\
\text { goals }\end{array}$ \\
\hline $\begin{array}{l}\text { Faculty } \\
\text { Administra- } \\
\text { tors (funding) } \\
\text { Professional } \\
\text { Development } \\
\text { Organizat- } \\
\text { ions }\end{array}$ & $\begin{array}{l}\text { Faculty } \\
\text { Students }\end{array}$ & $\begin{array}{l}\text { Evaluations } \\
\text { SLO's } \\
\text { Communities } \\
\text { of Practice } \\
\text { Lesson Plans } \\
\text { Knowledge } \\
\text { sharing }\end{array}$ & $\begin{array}{l}\text { Implement } \\
\text { minor } \\
\text { classroom } \\
\text { changes } \\
\text { (faculty } \\
\text { each try one } \\
\text { activity for a } \\
\text { term) } \\
\text { Change } \\
\text { within one } \\
\text { to three } \\
\text { depart- } \\
\text { ments }\end{array}$ & $\begin{array}{l}\text { Major } \\
\text { classroom } \\
\text { transfor- } \\
\text { mation (at } \\
\text { least five co- } \\
\text { constructed } \\
\text { activities/ } \\
\text { structures } \\
\text { per class) } \\
\text { Change } \\
\text { within ten } \\
\text { departments }\end{array}$ & $\begin{array}{l}\text { Increased } \\
\text { completion } \\
\text { of transfer } \\
\text { mathematics } \\
\text { within first } \\
\text { year for } \\
\text { students of } \\
\text { color } \\
\text { Students of } \\
\text { color using } \\
\text { mathematics } \\
\text { to improve } \\
\text { their } \\
\text { communities }\end{array}$ \\
\hline
\end{tabular}

\section{Limitations and recommendations for research}

This study focused specifically on power relations and how co-construction would break traditional power relations. There are limitations to the study including having students as co-researchers and teaching mathematics for social justice with a focus on critical consciousness. There are several other avenues for research that should be considered. 


\section{Students as co-researchers, co-authors}

One of the projects in the class was to investigate an educational issue, conduct a small research project, find or create solutions to the issues and send their findings to an appropriate administrator or leader on campus who will find the research interesting. This is a form of participatory action research where students investigate a problem they are facing and use the classroom to help improve their situations. Terry (2011) takes this a step further and includes his students as co-researchers conducting youth participatory action research in a math class to create counter stories to black males. A recommendation for research is for students to be co-researchers in the process of research in community college classes looking to break power relations in the class. Additionally, students also could be included in the writing process of the dissertation or scholarly article. Further recommended research includes investigating power relations through the words of students as co-authors with the researcher.

\section{Teaching mathematics for social justice (TMSJ) in community colleges}

Mathematics classrooms have been spaces for students to learn mathematics while understand their world better. The lyrical analysis and participatory action research projects were means for students to use mathematics to understand their worlds and improve their situations. Frankenstein (1990) used mathematics to teach university students about social inequities while other scholars looked to do the same, but in high school settings (Brantlinger, 2013; Gutstein, 2006). Further research should occur in 
community colleges focusing on the development of critical consciousness using mathematics. A high number of underserved students attend community colleges with diverse ages, lived experiences and educational backgrounds. It is important to learn how TMSJ works with community college students as they face similar oppressive structures as those in $\mathrm{K}-12$ settings and negotiating responsibilities as adults. In addition, there is little research conducted in higher education around TMSJ. This study was situated in a statistics course which lends itself very well to investigating social issues. Calculus based courses or courses that lead to Calculus like Algebra, Trigonometry or Pre-Calculus are also spaces to investigate how social justice can be infused both in high school and community college contexts.

While this study looked to privilege the voices of low-income students of color similar to the work of Martin (2006), further research should be conducted focusing on minoritized groups through their individual or intersectional identities using an Ethnic Studies lens. This study investigated power relations between students and faculty through co-constructing knowledge, learning environment and policies but did not investigate their views on power of using mathematics to impact their communities and school. This is another point of future research.

\section{Co-construction methodological variations}

The amount of items co-constructed in this study may not work for faculty or faculty may be interested in co-constructing more of the class than in this study. There 
is a tension in the amount of classroom to co-construct. The quantity of components in the classroom or how much more (or less) of each component in the classroom are coconstructed may be varied. In this study; grade weights, homework due date and knowledge through whole-class quizzes were co-constructed. Much more of the syllabus could have been co-constructed among other components of the class. This variation of co-construction is also important to research as faculty negotiate how much of the course to co-construct.

\section{Reflection as a scholar-practitioner (praxis discussion)}

While the process of writing this dissertation was hard, rocky, fun and transformative, I believe the struggles and joys I faced may resonate with other community college STEM faculty or educators who come from similar backgrounds as I do. I write this reflection for faculty who are considering doing educational research formally through graduate school, at their own site or at another school site. With the high stakes and high cost of graduate school, added layers of complexity and stress were imposed on this process whereas doing a research study through one's institutional research office may not have the pressure of completion.

The process of practitioner research was very reflective and included collaboration with critical friends. Writing teaching journals about lesson plans and what occurred in class each day gave space to reflect. I constantly asked myself "how is/can the class be co-constructed" and "how can/do students have power?" Writing data 
memos every two weeks allowed me to reflect on what occurred in class and I naturally found myself looking to improve student engagement, use co-construction and give students power as I wrote out my thoughts. Analysis of teaching journals revealed several points of reflections on how class could be improved specifically on how to engage students, co-construct the class and create a shared power dynamic.

\section{Teaching and studying math for years then transitioning to social science}

Throughout my whole career in mathematics, I have thought that math was a neutral subject; I believed math wasn't influenced by political factors and it was the language of the universe. I only was able to critique the neutrality of mathematics as I learned about social justice, systems of oppression and critically self-reflecting on how I contribute to systems of oppression. As I learned about how low-income students of color have been held down by society, I connected my newfound knowledge to my own history and experiences. I was made fun of for being poor, I was marginalized by my peers for not being able to afford going on trips or Disney on Ice, I was looked down upon because I grew up in the 'hood, and had low expectations from educators. Because my experiences felt normal, I carried forward my own negative experiences as a faculty member, seeing my students in deficits. My reflection about the systems of oppression, both as a victim and perpetrator, is what brought me to my studies today to break these systems today and my work moving forward. I felt the need to learn about the social sciences, particularly education. I always had an interest in psychology and sociology, 
and included many components of those fields into my classroom. Community college mathematics faculty are content experts by training, but educators by trade, a disjoint system for students. Education is complex and has multiple intersectionalities occurring at every moment and cannot be neutral, even mathematics.

\section{Imposter syndrome as low-income student of color; connection with} students

I rarely have seen myself in my teachers, yet I have often met educators who cared about me and didn't look like me. Perhaps they came from the same struggles as most of them were educators of color; they knew appropriate ways to engage me, discipline me and show love. Still, I faced so much marginalization that I struggled finding myself within the education system. Although I had older sisters and brother to give me some guidance, I questioned my place in the classroom and eventually found myself unwelcome. I found solace in peers who had similar struggles of confidence, often students of color, and worked with them to get through my education. This is a major reason why I look to build community in the classroom: for students who cannot identify or connect with the existing educations system to build a positive network of scholars to support each other. The bootstraps, meritocratic culture of higher education intentionally excludes the lived experiences of low-income students of color assuming that it only takes hard work in the classroom. Yes, it does take hard work, but the hard work argument alone does not account for structures that oppress students. It's easy for 
a middle-class white student to say that he or she worked hard at school, but these students were able to just focus on school and not on helping pay rent, familial responsibilities or facing educators that discounted their abilities and potential. The lack of understanding and critique of systems of oppression further perpetuate the structures that exclude low-income students from educational opportunities and this is a major reason why I am taking a critical perspective of mathematics education; it's more than getting a job, it's more than building weapons for the military. I believe classrooms are places for transformation and this study strongly suggests that faculty have the power to do so.

Many of my students have negative narratives about themselves as mathematics learners, some of the students almost sounding proud that they're not good with mathematics. I have had to battle similar negative narratives in myself about being a scholar of mathematics in an educational program. In particular, I must follow my own advice: ensure that the narrative is defined by me and not someone else and is one of hope.

\section{Scholar-practitioner tensions (positionality \& spectrum)}

As someone who had such a hard time in school, I naturally gravitated towards the practice of teaching. I remember graduate mathematics school where I was able to teach while taking graduate level mathematics coursework on content I would never teach. It was hard to negotiate such a difference in mathematics, yet I found a way to 
get through the graduate math content when it was not pleasant. I found so much joy in teaching a classroom and being a practitioner of education. I see myself more of a practitioner than a scholar. When I went into the EdD program, I felt the same way as I did in other educational settings: anxious, low confidence and like I didn't belong. I went to what worked for me: building relationships with my peers and looking for faculty who would support me. A subset of each would work out to my benefit, but I definitely leaned on them for support as they would do the same. My ongoing educational experience is something that I can share with students who also don't see themselves as scholars, but want to be scholars. I am able to provide insight and coaching on the educational growth process, something that Cheryl and Teena explicitly stated. The desire to share this knowledge with others shows that putting energy into being a practitioner is lower effort while developing as a scholar requires more effort. I see the scholar-practitioner dynamic as a spectrum, that all students are both and somewhere in the middle at all times, yet sit in different places on the spectrum within different contexts. For example, I have spent copious amounts of time processing my study which has resulted in less time spent on being a community college faculty member. Recently, I have spent more time being a community college faculty member which resulted in less productivity in writing my dissertation. I believe low-income students of color are always negotiating this spectrum: on the one hand, they have goals of graduation, earning higher income to provide for their family and being a role model 
for those in their community. On the other hand, they have practical responsibilities such as working multiple jobs to help pay rent, raising their younger siblings while the parents go to work and negotiating cultural differences between white, middle-class expectations of higher education and their household identities.

\section{Conclusion}

The current discourse around community college mathematics reform is focused on placement, acceleration and student completion with a focus on closing the achievement gap. While these are all necessary goals, especially when low-income students of color are placing, succeeding and graduating at rates much lower than their more affluent counterparts, the discussion of graduation or closing equity gaps are not enough (Gutierrez, 2008). Without teaching mathematics for social justice, educational institutions will continue to be a vehicle of social reproduction and perpetuate injustices against marginalized populations. As many researchers have conducted studies on mathematics for social justice, little to none have investigated power relations in the classroom or at the community college level. Using students' lived experiences requires understanding of oppressive structures they face and empathy to find ways to support their transformation; this requires political knowledge and the inclusion - not exclusion - of political education within mathematics. Co-construction addresses major goals of critical mathematics education by understanding the politics of math knowledge and understanding the politics of knowledge (Frankenstein \& Powell, 1989). 
In this practitioner research study, I used my insider knowledge and position to break power relations in the classroom through co-construction. Student interviewees, all low-income students of color from the nearby urban city of Bistoun, were found to believe faculty have all the power which makes sense because they grew up in lowincome neighborhoods where schools taught them to follow directions and behave (Anyon, 1980). Co-construction was found to create participatory opportunities for the students, who traditionally have not had a voice in their classrooms, and broke down power relations although the faculty member still had power. Utilizing co-construction is not farfetched for faculty and they can implement co-construction strategies immediately. For longer term change however, social justice, transformative leadership is required. In particular, administrators and faculty must lead to transgress, to challenge the existing systems of power and privilege that oppress marginalized communities. One time trainings are not sustainable and instead faculty should gather in communities of practice for on-going development which create a platform for deeper pedagogical change within the classroom.

As schools have traditionally and continually will disproportionately under serve low-income communities of color, community colleges will continue to be a landing place for these students to begin their higher education career as universities are selective while community colleges are open access. Providing access is insufficient as higher education was designed for white, middle-class students and many students of 
color graduate and complete their academic goals at rates far lower to their more affluent counterparts. While the discussion of completion is necessary, it is still not enough to break the existing systems of power and privilege that exist in the world. I call on all faculty to provide equitable teaching practices such as co-construction and work on transforming their classrooms to be a place of growing critical consciousness and empowerment towards action for students in their communities. 


\section{References}

Acevedo-Gil, N., Santos, R. E., Alonso, L., \& Solorzano, D. G. (2015). Latinas/os in community college developmental education increasing moments of academic and interpersonal validation. Journal of Hispanic Higher Education, 14(2), 101-127.

Aguirre, J., Herbel-Eisenmann, B., Celedón-Pattichis, S., Civil, M., Wilkerson, T., Stephan, M., Pape, S., \& Clements, D. H. (2017). Equity within mathematics education research as a political act: Moving from choice to intentional collective professional responsibility. Journal for Research in Mathematics Education, $48(2), 124-147$.

Ahlquist, R. (1991). Position and imposition: Power relations in a multicultural foundations class. Journal of Negro Education, 60(2), 158-169.

Ahn, R., \& Class, M. (2011). Student-centered pedagogy: Co-construction of knowledge through student-generated midterm exams. International Journal of Teaching and Learning in Higher Education, 23(2), 269-281.

Amit, M., \& Fried, M. N. (2005). Authority and authority relations in mathematics education: A view from an 8 th grade classroom. Educational Studies in Mathematics, 58(2), 145-168.

Anyon, J. (1980). Social class and the hidden curriculum of work. Journal of education, $67-92$. 
Apple, M. W., \& King, N. R. (1977). What do schools teach? Curriculum Inquiry, 6(4), $341-358$.

Ayers, D. F. (2005). Neoliberal ideology in community college mission statements: A critical discourse analysis. The review of higher education, 28(4), 527-549.

Bahr, P. R. (2008). Cooling out in the community college: What is the effect of academic advising on students' chances of success? Research in Higher Education, 49(8), 704-732.

Bailey, T. R., Jaggars, S. S., \& Jenkins, D. (2015). Redesigning America's community colleges. Cambridge, MA: Harvard University Press.

Bandura, A. (1989). Human agency in social cognitive theory. American psychologist, 44(9), 1175-1184.

Bartell, T. G. (2013). Learning to teach mathematics for social justice: Negotiating social justice and mathematical goals. Journal for Research in Mathematics Education, 44(1), 129-163.

Bartell, T. G., \& Johnson, K. R. (2013). Making unseen privilege visible in mathematics education research. Journal of Urban Mathematics Education, 6(1), 35-44. 
Bartolome, L. (1994). Beyond the methods fetish : Toward a humanizing pedagogy. Harvard Educational Review, 64(2), 173-194. http://doi.org/10.17763/haer.64.2.58q5m5744t325730

Boaler, J. (2002). Experiencing school mathematics: Traditional and reform approaches to teaching and their impact on student learning. New York, NY: Routledge.

Boaler, J., \& Greeno, J. G. (2000). Identity, agency, and knowing in mathematics worlds. In Boaler, J. (Ed.), Multiple perspectives on mathematics teaching and learning, (pp. 171-200). Santa Barbara, CA: Greenwood Publishing Group.

Bourdieu, P. (1973). Cultural Reproduction and Social Reproduction. In P. Jarvis \& C. Griffin (Eds.), Adult and Continuing Education Critical Concepts in Sociology (pp. 173-184). New York, NY: Routledge.

Bourdieu, P., \& Passeron, J. C. (1990). Reproduction in education, society and culture (Vol. 4). Thousand Oaks, CA: Sage.

Bourque, S. F. (2016). The impact of faculty development on community college adjunct faculty (Doctoral dissertation). Retrieved from Digital UNE. (80)

Brantlinger, A. (2013). Between politics and equations : Teaching critical mathematics in a remedial secondary classroom. American Educational Research Journal, 50(5), 1050-1080. 
Brantlinger, A. (2014). Critical mathematics discourse in a high school classroom: Examining patterns of student engagement and resistance. Educational Studies in Mathematics, 85(2), 201-220.

Brown, K. M. (2006). Leadership for social justice and equity: Evaluating a transformative framework and andragogy. Educational Administration Quarterly, 42(5), 700-745. http://doi.org/10.1177/0013161X06290650

California Community College's Chancellor's Office (n.d.) Basic Skills Progress Tracker. Management Information Systems Data Mart. Retrieved on (March 1, 2016) from http://datamart.ccco.edu/Outcomes/BasicSkills Cohort Tracker.aspx

Callahan, M. K., \& Chumney, D. (2009). " Write like college": How remedial writing courses at a community college and a research university position "at-risk" students in the field of higher education. Teachers College Record, 111(7), 16191664.

Capper, C. A., Theoharis, G., \& Sebastian, J. (2006). Toward a framework for preparing leaders for social justice. Journal of Educational Administration, 44(3), 209-224.

Charmaz, K. (2014). Constructing grounded theory. Thousand Oaks, CA: Sage Publications. 
Chen, W. (2016). Reading the world with mathematics: A critical mathematics literacy curriculum in Taiwan. International E-Journal of Advances in Education, 2(4), $156-166$.

Clance, P. R., \& Imes, S. A. (1978). The imposter phenomenon in high achieving women: Dynamics and therapeutic intervention. Psychotherapy: Theory, Research \& Practice, 15(3), 241.

Clark, B. R. (1960). The "cooling-out" function in higher education. Journal of Sociology, 65(6), 569-576.

Clark, B. R. (1980). The "cooling out" function revisited. Questioning the Community College Role: New Directions for Community Colleges, 8(4), 15-31.

Clarke, D. (2004). Patterns of participation in the mathematics classroom. In M.J. Høines \& A.B. Fuglestad (Eds.), Proceedings of the 28th Conference of the International Group for the Psychology of Mathematics Education, (Vol. 2, pp. 231-238). Bergen: Bergen University. http://www.emis.ams.org/proceedings/PME28/RR/RR121_Clarke.pdf

Cohen, A. M., \& Brawer, F. B. (2003). The American community college. San Francisco, CA: John Wiley \& Sons.

Cordell, D. (2017). African-American community college students' experiences with radical care. (Doctoral dissertation). Retrieved from ProQuest. (10276569) 
Cox, R. D., (2015). "You've got to learn the rules": A classroom-level look at low pass rates in developmental math. Community College Review, 43(3), 264-286.

Darling-Hammond, L. (2015). The flat world and education: How America's commitment to equity will determine our future. New York, NY: Teachers College Press.

Davis, J., \& Martin, D. (2008). Racism, assessment, and instructional practices: Implications for mathematics teachers of African American students. Journal of Urban Mathematics Education, 1(1), 10-34.

Deil-amen, R., \& Rosenbaum, J. E. (2002). The unintended consequences of stigmafree remediation. Sociology of Education, 75(3), 249-268.

Delpit, L. D. (1992). Education in a multicultural society: Our future's greatest challenge. The Journal of Negro Education, 61(3), 237-249.

Dougherty, K. \& Karen, D., (2005). Higher education and the color line: College access, racial equity and social change. Cambridge, MA: Harvard Education Press.

Duncan-Andrade, J, (2007). Gangstas, wankstas, and ridas: Defining, developing, and supporting effective teachers in urban schools. International Journal of Qualitative Studies in Education, 20(6), 617-638.

http://doi.org/10.1080/09518390701630767 
Duncan-Andrade, J. (2010). To study is a revolutionary duty. In G. Goodman (Ed.), Educational Psychology Reader: The Art and Science of How People Learn, (pp. 165-178). New York: Peter Lang.

Emdin, C. (2016). For White folks who teach in the hood... and the rest of $y^{\prime}$ all too: Reality pedagogy and urban education. Boston, MA: Beacon Press.

Evans, J., Morgan, C., \& Tsatsaroni, A. (2006). Discursive positioning and emotion in school mathematics practices. Educational Studies in Mathematics, 63(2), 209226. http://doi.org/10.1007/s10649-006-9029-1

Foucault, M. (1982). The Subject and Power. Critical Inquiry, 8(4), 777-795.

Foucault, M. (2012). Discipline \& punish: The birth of the prison (2nd ed.). New York, NY: Vintage.

Fraenkel, J.R., Wallen, N. \& Hyun, H. (2015). How to design and evaluate research in education (9th Ed.). New York, NY: McGraw-Hill.

Frankenstein, M. (1990). Incorporating race, gender, and class issues into a critical mathematical literacy curriculum. The Journal of Negro Education, 59(3), 336347. 
Frankenstein, M. \& Powell, A. B. (1989). Empowering Non-Traditional College Students. Science and Nature, 9/10, 100-112. Retrieved from https://doi.org/doi:10.7282/T33R0R9R

Franquiz, M., \& del Carmen Salazar, M. (2004). The transformative potential of humanizing pedagogy: Addressing the diverse needs of Chicano/Mexicano students. The High School Journal, 87(4), 36-53.

Freire, P. (1970). Pedagogy of the oppressed. New York, NY: Herder and Herder.

French, J. R., Raven, B., \& Cartwright, D. (1959). The bases of social power. In D. Cartwright (Ed.), Studies in social power, (pp. 150-167). Ann Arbor, MI: Institute for Social Research.

Geiser, S., \& Atkinson, R. C. (2013). Beyond the master plan: The case for restructuring baccalaureate education in California. Callfornia Journal of Politics and Policy, 5(1), 67-123.

Gonzalez, L. (2009). Teaching mathematics for social justice: Reflections on a community of practice for urban high school mathematics teachers. Journal of Urban Mathematics Education, 2(1), 22-51.

Gore, J. M. (1995). On the continuity of power relations in pedagogy. International Studies in Sociology of Education, 5(2), 165-188. 
Gregson, S. A. (2013). Negotiating social justice teaching: One full-time teacher's practice viewed from the trenches. Journal for Research in Mathematics Education, 44(1), 164-198.

Gresalfi, M., Martin, T., Hand, V., \& Greeno, J. (2009). Constructing competence: An analysis of student participation in the activity systems of mathematics classrooms. Educational Studies in Mathematics, 70(1), 49-70. http://doi.org/10.1007/s10649-008-9141-5

Grubb, W. N., (2010, September). The quandaries of basic skills in community colleges: Views from the classroom. (NCPR Working Paper). Paper presented at the National Center for Postsecondary Research developmental education conference, New York, NY.

Gutierrez, J. F. (2015). Signs of power: A critical approach to the study of mathematics cognition and instruction (Doctoral dissertation). Retrieved from ProQuest. (10186625)

Gutiérrez, R. (2002). Enabling the practice of mathematics teachers in context: Toward a new equity research agenda. Mathematical Thinking and Learning, 4(2-3), 145187. 
Gutierrez, R. (2008). A " gap-gazing " fetish in mathematics education? Problematizing research on the achievement gap. Journal for Research in Mathematics Education, 39(4), 357-364. Retrieved from http://www.jstor.org/stable/40539302

Gutiérrez, R. (2009). Embracing the inherent tensions in teaching mathematics from an equity stance. Democracy \& Education, 18(3), 9-16.

Gutiérrez, R. (2013). The sociopolitical turn in mathematics education. Journal for Research in Mathematics Education, 44(1), 37-68.

Gutiérrez, R. (2017). Political conocimiento for teaching mathematics: Why teachers need it and how to develop it. In S. Kastberg, A. M. Tyminski, A. Lischka \& W. Sanchez (Eds.), Building support for scholarly practices in mathematics methods, (pp. 11-38). Charlotte, NC: Information Age.

Gutierrez, R. (2018). Rehumanizing mathematics for classrooms and citizens [video]. Retrieved from rtsp://videos.msri.org/data/000/030/696/original/4-Plenary.mp4

Gutstein, E. (2008). Reinventing Freire: Mathematics education for social transformation. In J. F. Matos, P. Valero, K. Yasukawa (Eds.), Proceedings of the Fufth International Mathematics Education and Society Conference (Vol. 1, pp. 924). Albufeira, Portugal: Aalborg University.

Gutstein, E. (2009). The politics of mathematics education in the US: Dominant and counter agendas. Culturally responsive mathematics education, 137-164. 
Gutstein, E. (2012). Mathematics as a weapon in the struggle. In O. Skovsmose, \& B. Greer (Eds.), Opening the Cage : Critique and Politics of Mathematics Education (pp. 23-48). Rotterdam, The Netherlands: Sense Publishers.

Gutstein, E. (2016). "Our issues, our people - math as our weapon": Critical mathematics in a Chicago neighborhood high school. Journal for Research in Mathematics Education, 47(5), 454-504.

Hand, V. M. (2010). The co-construction of opposition in a low-track mathematics classroom. American Educational Research Journal, 47(1), 97-132.

Herr, K., \& Anderson, G. L. (2014). The action research dissertation: A guide for students and faculty. Thousand Oaks, CA: Sage Publications.

Heyd-Metzuyanim, E. (2013). The co-construction of learning difficulties in mathematics-teacher-student interactions and their role in the development of a disabled mathematical identity. Educational Studies in Mathematics, 83(3), 341368.

Huerta, T. M. (2011). Humanizing pedagogy: Beliefs and practices on the teaching of Latino children. Bilingual Research Journal, 34(1), 38-57. http://doi.org/10.1080/15235882.2011.568826

Isern, J., Orme, S., Rasmussen, A., Reid, A., \& Roe, T. (2016). Thematically organized English sections (TOES) at Spokane Community College: Creating sustainable 
faculty professional development. Teaching English in the Two Year College, $43(4), 423$.

Jamieson, D. W., \& Thomas, K. W. (1974). Power and conflict in the student-teacher relationship. The Journal of Applied Behavioral Science, 10(3), 321-336.

Jill, A. (2015). Invisible influence : New forms of cooling out in community colleges (Doctoral dissertation). Retrieved from ProQuest. (3741035)

Karp, M. M., O'Gara, L., \& Hughes, K. L. (2008). Do support services at community colleges encourage success or reproduce disadvantage? An exploratory study of students in two community colleges. (CCRC Working Paper No. 10). New York, NY: Columbia University, Teachers College, Community College Research Center.

Kearney, P., Plax, T. G., Richmond, V. P., \& McCroskey, J. C. (1985). Power in the classroom III: Teacher communication techniques and messages. Communication Education, 34(1), 19-28.

Kohl, H. (1994). "I won't learn from you" and other thoughts on creative maladjustment. New York: New Press.

Kokka, K. (2015). Addressing dilemmas of social justice mathematics instruction through collaboration of students, educators, and researchers. Educational Considerations, 42(3), 13-21. 
Ladson-Billings, G. (1995). Toward a theory of culturally relevant pedagogy. American educational research journal, 32(3), 465-491.

Ladson-Billings, G., \& Tate IV, W. F. (1995). Toward a critical race theory of education. Teachers College Record 97(1), 47-68.

Lampert, M. (1990). When the problem is not the question and the solution is not the answer: Mathematical knowing and teaching. American Educational Research Journal, 27(1), 29-63.

Langer-Osuna, J. (2007, September). Toward a framework for the co-construction of learning and identity in the mathematics classroom. Paper presented at the Second Annual Socio-cultural Theory in Educational Research and Practice Conference: Theory, Identity and Learning, Manchester, England.

Langer-Osuna, J. (2015). Linear equations and rap battles: how students in a wired classroom utilized the computer as a resource to coordinate personal and mathematical positional identities in hybrid spaces. Mathematics Education Research Journal, 27(1), 51-64.

Liu, K., Miller, R., \& Jahng, K. E. (2016). Participatory media for teacher professional development: Toward a self-sustainable and democratic community of practice. Educational Review, 68(4), 420-443. http://doi.org/10.1080/00131911.2015.1121862 
Martin, D. B. (2003). Hidden assumptions and unaddressed questions in mathematics for all rhetoric. The Mathematics Educator, 13(2), 7-21.

Martin, D. B. (2006). Mathematics learning and participation as racialized forms of experience: African American parents speak on the struggle for mathematics literacy. Mathematical Thinking \& Learning: An International Journal, 8(3), 287307.

McGee, E. O., \& Martin, D. B. (2011). "You would not believe what I have to go through to prove my intellectual value!" Stereotype management among academically successful Black mathematics and engineering students. American Educational Research Journal, 48(6).

Meek, A. (1989). On creating "ganas": A conversation with Jaime Escalante. Educational Leadership, 46(5), 46-47.

Mesa, V. (2012). Achievement goal orientations of community college mathematics students and the misalignment of instructor perceptions. Community College Review, 40(1), 46-74. http://doi.org/10.1177/0091552111435663

Mueller, M. F. (2009). The co-construction of arguments by middle-school students. Journal of Mathematical Behavior, 28(2), 138-149. 
O'Gara, L., Mechur Karp, M., \& Hughes, K. L. (2009). Student success courses in the community college: An exploratory study of student perspectives. Community College Review, 36(3), 195-218.

Oppland-Cordell, S. B. (2014). Urban Latina/o undergraduate students' negotiations of identities and participation in an emerging scholars calculus I workshop. Journal of Urban Mathematics Education, 7(1), 19-54.

Parker, C., Morrell, C., Morrell, C., \& Chang, L. (2016). Shifting understandings of community college faculty members: Results of an equity-focused professional development experience. The Journal of Faculty Development, 30(3), 41-48.

Perry, M., Bahr, P.R., Rosin, M., \& Woodward, K.M., (2010). Course-taking patterns, policies, and practices in developmental education in the California community colleges. Mountain View, CA: EdSource. Retrieved from http://edsource.org/wpcontent/publications/FULL-CC-DevelopmentalCoursetaking.pdf

Pilcher, J. K. (1994). The value-driven meaning of grades. Educational Assessment, 2(1), 69-88.

Powell, A. B. (2004). The diversity backlash and the mathematical agency of students of color. In M.J. Høines \& A.B. Fuglestad (Eds.), Proceedings of the 28th Conference of the International Group for the Psychology of Mathematics Education, (Vol. 1, pp. 37-54). Bergen: Bergen University. 
Powell, A. B., \& Frankenstein, M. (2002). Toward liberatory mathematics: Paulo Freire's epistemology and ethnomathematics. In C. Lankshear \& P. McLaren (Eds.), The politics of liberation: Paths from Freire (pp. 94-119). New York, NY: Routledge.

Prasad, R. (2014). Classroom experiences that predict sense of belonging and academic performance within the community college math classroom (Doctoral dissertation). Retrieved from ProQuest. (3670611)

Quist, M. E. (2015). Exploring positive learning experiences in the community college mathematics classroom in a midwestern state: A qualitative study (Doctoral dissertation). Retrieved from ProQuest. (3701603)

Roache, J. E., \& Lewis, R. (2011). The carrot, the stick, or the relationship: what are the effective disciplinary strategies? European Journal of Teacher Education, 34(2), 233-248.

Romano, R. M. (2004). "Cooling out" revisited: Some evidence from survey research. Community College Journal of Research and Practice, 28(4), 311-320.

Russo, M. (2015). Quantitative literacy and co-construction in a high school math course. Numeracy, 8(1), 1-23. 
Russo, M. F. (2016). Co-construction as a critical approach to mathematics education. In F. Naiditch (Ed.), Developing critical thinking: From theory to classroom practice, (pp. 67-86). Lanham, MD: Rowman \& Littlefield Publishers.

Salazar, M. (2013). A humanizing pedagogy: Reinventing the principles and practice of education as a journey toward liberation. Review of Research in Education, 37(1), 121-148. http://doi.org/10.3102/0091732X12464032

Saldaña, J. (2015). The coding manual for qualitative researchers. Thousand Oaks, CA: Sage Publications.

Seidman, I. (2013). Interviewing as qualitative research: A guide for researchers in education and the social sciences. New York, NY: Teachers College Press.

Shields, C. M. (2004). Dialogic leadership for social justice: Overcoming pathologies of silence. Educational administration quarterly, 40(1), 109-132.

Sidman-Taveau, R., \& Hoffman, M. (2018). Making change for equity: An inquirybased professional learning initiative. Community College Journal of Research and Practice, 1-24.

Skovsmose, O. (1985). Mathematical education versus critical education. Educational Studies in Mathematics, 16(4), 337-354. 
Skovsmose, O. (1994). Towards a critical mathematics education. Educational Studies in Mathematics 27(1), 35-57.

Simic-Muller, K., Fernandes, A., \& Felton-Koestler, M. D. (2015). “I just wouldn’t want to get as deep into it": Preservice teachers' beliefs about the role of controversial topics in mathematics education. Journal of Urban Mathematics Education, 8(2), 53-86.

Solórzano, D. G., \& Yosso, T. J. (2002). Critical race methodology: Counterstorytelling as an analytical framework for education research. Qualitative Inquiry, 8(1), 23-44.

Spencer, J. A., \& Hand, V. M. (2015). The racialization of mathematics education. In L. Drakeford (Ed.), The race controversy in American education. (pp. 237-258). Santa Barbara, CA: Praeger

Stroud, R. S. (2009). Theorizing African American women's leadership in predominantly white institutions of higher education (Doctoral dissertation). Retrieved from ProQuest. (3352309).

Stephan, J. L., Rosenbaum, J.E., and Person, A.E. (2009). Stratification in college entry and completion. Social Science Research 38(3), 572-593.

Tate, W. F. (2004). Brown, political economy, and the scientific education of African Americans. In R.E. Floden (Ed.), Review of Research in Education (pp. 147-184). 
Washington, DC: American Educational Research Association.

http://doi.org/10.3102/0091732X028001147

Tauber, R. T. (1985). Power bases: their application to classroom and school management. Journal of Education for Teaching, 11(2), 133-144.

Teddlie, C., \& Yu, F. (2007). Mixed methods sampling: A typology with examples. Journal of mixed methods research, 1(1), 77-100.

Terry, C. L. (2011). Mathematical counterstory and African American male students: Urban mathematics education from a critical race theory perspective. Journal of Urban Mathematics Education, 4(1), 23-49.

Theoharis, G. (2007). Social justice educational leaders and resistance: Toward a theory of social justice leadership. Educational administration quarterly, 43(2), 221-258.

Tzanakis, M. (2011). Bourdieu's social reproduction thesis and the role of cultural capital in educational attainment: A critical review of key empirical studies. Educate , 11(1), 76-90.

Twombly, S., \& Townsend, B. K. (2008). Community college faculty what we know and need to know. Community College Review, 36(1), 5-24. 
Valadez, J. R. (2000). Searching for a path out of poverty: Exploring the achievement ideology of a rural community college. Adult Education Quarterly, 50(3), 212230.

Valero, P. (2007). What has power got to do with mathematics education. Philosophy of Mathematics Education Journal, 21(13), 1-13.

van Es, E. A., Hand, V., \& Mercado, J. (2017). Making Visible the Relationship Between Teachers' Noticing for Equity and Equitable Teaching Practice. In Teacher Noticing: Bridging and Broadening Perspectives, Contexts, and Frameworks (pp. 251-270). New York, NY: Springer.

Yackel, E., \& Cobb, P. (1996). Sociomathematical norms, argumentation, and autonomy in mathematics. Journal for Research in Mathematics Education, 27(4), $458-477$.

Yackel, E., Rasmussen, C., \& King, K. (2000). Social and sociomathematical norms in an advanced undergraduate mathematics course. The Journal of Mathematical Behavior, 19(3), 275-287.

Zavala, M. D. R. (2014). Latina/o youth's perspectives on race, language, and learning mathematics. Journal of Urban Mathematics Education, 7(1), 55-87.

Zavala, M.D.R. (2016). Methods, maps and meaningful mathematics. TODOS: Mathematics for ALL, 7(1), 37-44. 


\section{Appendix A: Interview Protocol}

1. What is your major?

2. Why do you need to take this statistics course?

3. Where do you plan on transferring to? (4-year university)

4. What did you enjoy about the class?

5. What issues did you face outside of class that may have distracted you?

6. How could the class be improved?

7. Compare this class to other math classes in terms of your interactions with the teacher/professor.

8. Did you feel like you had a say in classroom policies? Give examples. (How do you feel the structure of the class allowed you to have choice?)

9. Was your voice heard in class? If so, what was it that made you feel that it was heard?

a. When was it heard and when was it not?

10. Are there other things that were missed regarding having a say about the classroom?

11. Define power in the classroom.

12. What ways can students be given power in the classroom?

a. Did you feel this occurred during the semester? 
13. What restrictions, if any, should be held about giving students power in the classroom? (How much control should teachers have in the classroom? Explain)

14. In what ways do you feel teachers abuse their power? Give examples of when this occurred this semester in our class.

15. Would it be beneficial to you if there was shared power between students and faculty in the class? Please explain why.

16. Do you think that giving power to students will help more students who struggle academically to succeed in math courses? If yes, then what should be done? What suggestions do you have for teachers on this topic?

17. What else would you like to add to the topic of power that I have not asked?

18. Are you from Oakland? Why is it important for you to be interviewed on a topic like this?

19. Do you have anything else you want to add or any questions for me? 
Appendix B: Syllabus

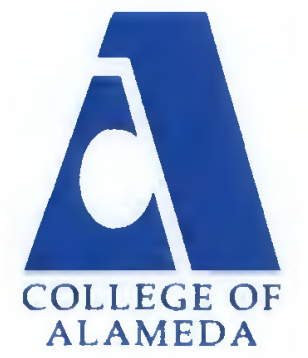

Instructor: Vanson

Nguyen

Email:

vansonnguven $(\mathfrak{a})$ peralta.edu
Office: L230

Office phone:

(510) 748-2183

\section{vansonneuven a peralta.edu}

\section{Math 13 \\ Introduction to Statistics - Fall 2017 \\ Code 40409 \\ MWTh 8:00am-9:50am (D-206) \\ Office Hours: MW 10:30-11:30 in L230}

Or by appointment

Study Group: Th 10:00 - 11:00am

COURSE ID: 24093 - Enrollment Key:

Math $213+13$ : This is a new pilot support course for students with the need to take statistics for their major only (not calculus). The course meets in room D-206 on Mondays and Wednesdays, room C-208 on Thursdays. This will feel like one big course that meets 3 times a week instead of two separate courses.

Course Description: Introduction to theory and practice of statistics: Collecting data: Sampling, observational and experimental studies. Organizing data: Univariate and bivariate tables and graphs, histograms. Describing data: Measures of location, 
spread, and correlation. Theory: Probability, random variables; binomial and normal distributions. Drawing conclusions from data: Confidence intervals, hypothesis testing, z-tests, t-tests, and chi-square tests; one-way analysis of variance. Regression and nonparametric methods.

Study group: We have partnered with the Learning Resource Center to have a designated study group with tutor for our class. It meets right after class for an hour and meets in the Math Lab L-202D.

Math 13 Student Learning Outcomes: By the end of this course, students will be able to do the following:

1. Develop problem solving abilities: Synthesize data; translate words into math language; and construct an abstract model that describes the problem.

2. Compute and interpret probabilities using binomial and normal distributions.

3. Perform and interpret hypothesis tests.

Prerequisite: Completion of Math 203 or Math 206 with a grade of C or better or multiple measures.

\section{Required Materials}

- Textbook: Open Intro Statistics $3^{\text {rd }}$ Edition by Diez, Barr \& Cetinkaya-Rundel (https://drive.google.com/file/d/0B-DHaDEbiOGkc1RycUtIcUtlelE/view)

- Graphing Calculator: (Texas Instruments) TI83 or TI84. We will frequently use this during class in addition to exams and homework.

Course Websites 
Canvas: http:/learn.peralta.edu Here you will

find the following

Course announcements

Assignments

Grades

Forums
My Open Math:

http://myopenmath.com

- This is a free site and

homework will be

completed here (see

below)

\section{Technology policy}

- During exams, you are not allowed to use the following:

- Cell phones of any type, Itouch, Tablets, Laptops even if your graphing calculator is on one of these devices

- Anything that connects to the internet or anything that allows you to communicate with others.

\section{Grading}

- Homework (20\%): Homework will be online. Working ahead is stronglv encouraged!

- Online Homework: You will need to sign up for the course by going to http://myopenmath.com. Use COURSE ID: 24093 \& Enrollment Key: ohhello123. The whole semester's homework has been created so you can work ahead. Everyone will have 10 late homework passes meaning you will be allowed to do late assignments up to 10 times; you'll need to redeem the late pass before the homework is due.

- Forum Posts: There will be a few forums on Canvas and each student will receive points based on participation. Late submissions will not earn points.

- Other assignments on Canvas: completed reflections will afford you points, all posted on Canvas. Late submissions will not be accepted for credit.

- Exams/Final (40\%): Exams will be 20\% take home and $80 \%$ in class. There will be 3 . If the last exam is higher than any of the previous 2 scores, it will replace the lowest one.

- Quizzes (10\%):

- Ouiz: There will be quizzes all the time, some easy and some hella easy. Quizzes will be group; the purpose is to give you awareness of your learning, networking, and 
building community. Quizzes will be worth 2-10 points. Make up quizzes are not given.

- Projects (30\%): There are a few items that fall under this category. All prompts will be provided on Canvas.

- Election (20 points)

- Lyrical Analysis (50 points)

- Misleading statistics (25 points)

- Statistics and Social Issues (5 points)

- Improving the College of Alameda (100 points)

- Extra Credit: You can receive extra credit in several ways:

- Spending time in the Learning Resource Center (L202D) will afford you variable amount of extra credit. You can obtain your hours by checking one of the log-in screens; you can just take a picture of your hours and email it to me.

- 20 homework points will be earned for students spending 18 hours or more, 50 homework points will be earned for students spending 36 hours or more by the end of week 8. These hours are due October 13.

- on an exam of your choice - 5\% will be earned for students spending 36 hours or more, $10 \%$ will be earned for students spending 72 hours or more for the entire semester. These hours are due December 8.

- Success events: You can go to campus events for points. These can be on campus or at another Peralta campus, but must be discussed with me first. Each will be worth 5 points towards homework and is due on the last day of instruction of that month. Up to 75 points may be earned through this. The guidelines are as follows, 1 page, 12 point font, Times New Roman, double spaced:

- Describe the event/activity. What was the purpose of the event/activity?

- What did you learn?

- Who did you meet? Be specific with names and titles.

- Explain how your participation at the event helps your success in our class.

- Note: You may skip the first bullet point if you take a picture at the event and upload it to a social network of yours, providing me with visual proof through any means of technology. 
Scoring Rubric: Below are the explanations of points awarded for problems worth 3, 4, and 5 points. Most exam questions will be graded using these rubrics. Problems worth more points will be scored proportionately.

\begin{tabular}{|l|l|l|l|l|}
\hline Points & \multicolumn{1}{|c|}{3} & \multicolumn{1}{|c|}{2} & \multicolumn{1}{|c|}{} \\
\hline Explanation & $\begin{array}{l}\text { Correct solution } \\
\text { with proper steps }\end{array}$ & $\begin{array}{l}\text { Correct concept } \\
\text { with incorrect } \\
\text { steps }\end{array}$ & $\begin{array}{l}\text { Major } \\
\text { concept error }\end{array}$ & $\begin{array}{l}\text { Blank, or } \\
\text { steps have } \\
\text { nothing to do } \\
\text { with problem }\end{array}$ \\
\hline
\end{tabular}

\begin{tabular}{|c|c|c|c|c|c|}
\hline Points & 4 & 3 & 2 & 1 & 0 \\
\hline Explanation & $\begin{array}{l}\text { Correct } \\
\text { solution } \\
\text { with proper } \\
\text { steps }\end{array}$ & $\begin{array}{l}\text { Correct } \\
\text { concept } \\
\text { with } 1 \\
\text { minor } \\
\text { mistake }\end{array}$ & $\begin{array}{l}\text { Major } \\
\text { Concept } \\
\text { error with } \\
\text { some correct } \\
\text { steps }\end{array}$ & $\begin{array}{l}\text { Major } \\
\text { concept error } \\
\text { with one } \\
\text { correct step }\end{array}$ & $\begin{array}{l}\text { Blank, or } \\
\text { steps have } \\
\text { nothing to } \\
\text { do with } \\
\text { problem }\end{array}$ \\
\hline
\end{tabular}

\begin{tabular}{|c|c|c|c|c|c|c|}
\hline Points & 5 & 4 & 3 & 2 & 1 & 0 \\
\hline Explanation & $\begin{array}{l}\text { Correct } \\
\text { solution } \\
\text { with } \\
\text { proper } \\
\text { steps }\end{array}$ & $\begin{array}{l}\text { Correct } \\
\text { concept } \\
\text { with } 1 \\
\text { minor } \\
\text { mistake }\end{array}$ & $\begin{array}{l}\text { Correct } \\
\text { concepts } \\
\text { with few } \\
\text { minor } \\
\text { mistakes }\end{array}$ & $\begin{array}{l}\text { Major } \\
\text { concept } \\
\text { error with } \\
\text { some } \\
\text { correct } \\
\text { steps }\end{array}$ & $\begin{array}{l}\text { Major } \\
\text { concept } \\
\text { error } \\
\text { with one } \\
\text { correct } \\
\text { step }\end{array}$ & $\begin{array}{l}\text { Blank, or } \\
\text { steps have } \\
\text { nothing to } \\
\text { do with } \\
\text { problem }\end{array}$ \\
\hline
\end{tabular}

Missing class/withdrawing: Contact me if you miss class for any reason. If you

are absent more than twice the number of meetings scheduled per week ( 3 absences),

the instructor reserves the right to remove your name from the class roll. That is, if you

miss 7 classes, I have the right to drop you. However. it is un to vou to drop a course.

You are required to file a drop or withdrawal through Passport or Admissions and

Records; if you fail to do so, you may receive a grade of $\mathrm{F}$ for the class. 
Tutoring: The Learning Resource Center is located on the second floor of the library. Drop in tutoring is available most of the day. You may receive extra credit based on the number of hours you spend there (see above).

DSPS: In coordination with the DSPS office, reasonable accommodation will be provided for eligible students with disabilities. If you do not yet have an accommodation letter, please contact the DSPS office in D-1 17 at (510) 748-2328

Grade Distribution

90-100\%

$80-89 \%$

$70-79 \%$

$50-69 \%$

passing)

$0-49 \%$

passing)
Important Dates:

A September 4 Last day to add or drop

B September 4

C September 5

D (not October 26

F (not November 10 with refund

Last day to drop without a 'W' Labor Day, No school Faculty FLEX, No class

Veteran's day, No school

November $15 \quad$ Last day to drop with a 'W'

November 23-24 Thanksgiving, No School December 11 Final

\section{Academic Integrity}

- Academic dishonesty will have serious consequences. The FIRST offense (and any subsequent offense) may result in any or all of the following:

- Receive a zero on the item in question.

- Lowering of the course grade (in addition to the above penalty).

- Course failure.

- Report to the Dean of Enrollment Services (maintains a record of all incidents of cheating).

- Under the standards of Academic Sanctions, you may be subject to any or all of the following on the FIRST offense (and any subsequent offense):

- A warning 
- Temporary exclusion from an activity or class.

- Censure.

- Disciplinary Probation

- Suspension

- Expulsion

- You are responsible for adhering to the Code of Student Conduct outlined in the College Catalog.

- Please see the Student Handbook (link available on the course website) or Course Catalog for the college's definitions and policies on academic dishonesty and its consequences.

\section{Resources}

- DSPS (D-117) http://alameda.peralta.edu/dsps

- EOPS/CARE/Cal Works (A101) http://alameda.peralta.edu/eops-care/

- Learning Resource Center (L234,L235,L226) http://alameda.peralta.edu/learningresource-center/

- CALWORKS (A101) http://alameda.peralta.edu/calworks/

- One-Stop Career Center (Portable P) http://alameda.peralta.edu/one-stop-career-center/

- Transfer Program (A Building - Welcome Center) http://alameda.peralta.edu/transferprogram/

- Financial Aid (A Building - Welcome Center) htto://alameda.peralta.edu/financial-aid/

- Student Leadership And Development ( $F$ building $2^{\text {nd }}$ floor) http://alameda.peralta.edu/student-leadership-office/

- Health Center(F105) http://alameda.peralta.edu/health-services/

- Veterans Resource Center (G building next to Gym, $2^{\text {nd }}$ floor) http://alameda.peralta.edu/veterans-services/ 


\section{Appendix C: Lyrical Analysis Project Prompt}

Part 1

Each group (up to 4) will choose a hip-hop album. If you would like for me to choose one for you, I will do so.

Use lyric websites (such as rapgenius.com, atozlyrics.com) to find lyrics to the songs on the album. If you are unable to find lyrics to the album of your choice, you will either need to find another album or publish the lyrics yourself. Once you find the sites with all the lyrics, you will count the number of references to the following themes:

- Promotion of money

- Encouraged use of drugs and alcohol

- Demeaning of women

- Promoting of Violence

In addition, you will need to identify at least 2 more themes to count references. (5 points)

Also, select an issue in society that you will connect to the album. (5 points) 
Part 2

In each song, count the number of times the common themes are mentioned and tally them. Count them for each time a theme was referenced: each time a theme is referenced in a chorus (hook), each counts as one; if there are multiple mentions to a theme in the same sentence, count each one. Using this data, find the mean, median, mode, and standard deviation of number of references to the themes; include any outliers. (10 points)

For each time a theme is referenced (mentioned) in a song, keep track of those lyrics. Compile a list of all lyrics that refer to the common themes either sorted by theme or song. (15 points).

Provide a brief history of the artist and connect it to the content of the lyrics. Use proper citation. ( 5 points) 
Part 3

Write up - turn in a written report with:

$>$ (10 points) Album title, artist, common themes and social issue

$>$ (10 points) The tallies (counts) of references to each theme and statistical analysis outlined in part 2

$>$ (10 points) Two Visual representations (graph or chart from class) of your data

$>$ (15 points) List of lyrics where themes were referenced

$>$ (5 points) Connect artist's history with lyrics

$>$ (5 points) Argument on how you believe the album addresses the social issue you chose, sharing specific lyrics that support your argument

$>$ (3 point) References

Presentation -create a presentation and provide all of the information you found

in parts $1 \& 2$. In addition, include the following:

1. (10 points) Highlights from parts $1 \& 2$. Be sure to include

a. Album title, artist, common themes and social issue

b. Statistical analysis

c. Any connections you found between the history of the artist and content of their lyrics

2. (5 points) Pick one of the visual forms of representation (graph or chart) from your write up.

3. (5 points) Create an argument on how you believe the album addresses the issue you selected in part 1; share specific lyrics that support your argument

4. (2 points) Favorite song from the album and why

5. (5 points) Reporting of materials is clear and within time frame

6. (3 points) One Slide/Page of References 
Part 4

(9 points) Each group will submit their findings to one other person not in our class. This may be a high school/middle school student, educator, parent, record label or the artists to name a few options, although if you choose another individual, make sure you share it with me first. In this email, use professional language, carbon copy (cc) me and share information on the following:

You are a student at the College of Alameda and did a lyrical analysis of a hiphop album

Mean numbers of references to themes of highest mean (for example: violence was referenced an average (mean) of 4.6 times per track)

Social Issue linked to the album and argument on how you believe the album addresses the issue you selected in part 1

Link to your presentation 
Appendix D: Improving the Campus Project Prompt

\section{Part 1}

The purpose of this project is to provide possible answers to the question "How do we improve the campus?" First, you and your group will choose an issue related to education. Here is a list of a few:

- Lack of student motivation

- Transition to college

- Poverty

- Low success rates
- Resources at the campus

- Interactions with faculty and staff (experience at the school)

- Outreach to high schools, adult schools and the community

Choose one from the above or another topic: should you choose another topic from the ones above, you must get my approval.

Select a presentation site: Not using PowerPoint, google presentations or prezi, use one of the following websites to create an engaging presentation. Get acquainted with the site now:

a. Slidescarnival.com

b. Projeqt.com

c. Genial.ly

d. Sway.com

e. Visme.co

f. Slidedog.com

(5 points) Designate at least 2 people per task:

Survey development

Data gathering (should be the whole group)

Data analysis

Report write up

Proposal research 


\section{Creating the Presentation}

Follow up email (1 person)

Create a plan if someone does not do their part of the project. (5 points) 


\section{Part 2}

Develop a 5-10 question survey that will address the issue you chose; the purpose is to collect data to improve the school. Following, each group will write 2-3 proposals for improvement. This survey at least one of each of the following: open ended question, open ended question that prompts a number (but not on a scale), multiple choice likert scale (1-5), and Yes/No (True/False). Use appropriate questions that will help you find the inferential statistics below. Your survey must be able to gather data that will:

- Determine measures of center

- Find probabilities using binomial distribution

- Find confidence intervals

- Employ hypothesis testing

You can use paper or online survey using google docs. Tips on creating the survey:

* Don't ask two questions in one

* Don't ask leading questions, questions that assume something

Each group will need to administer at least 100 surveys $(n=100)$. As part of your data gathering, you must record how, where and when you surveyed and how many you surveyed. Below are a few examples

- Surveyed my English 1A class which meets Wednesday from 1-4pm ( $n=25)$

- Passed out surveys at a campus event on Tuesday from 11:30am-1pm $(n=15)$

- Had my friends complete the survey; they are mostly Asian, half being from Oakland, the other half being from San Leandro $(n=20)$ 
- Went to Southshore on a Tuesday morning at 10am $(n=30)$

- Went to Southshore on a Saturday afternoon at $3 \mathrm{pm}(n=40)$

Additionally, you will need be comparing two populations with similar demographics that you surveyed.

To enter the data into a spreadsheet, I recommend using the following format:

\begin{tabular}{|c|c|c|c|c|}
\hline & $\begin{array}{ll} & \text { Question } \\
1 & \end{array}$ & $2 \quad$ Question & $\begin{array}{ll} & \text { Question } \\
3 & \end{array}$ & $\begin{array}{l}\text { Question } \\
4\end{array}$ \\
\hline $\begin{array}{l}1^{\text {st }} \\
\text { survey }\end{array}$ & & & & \\
\hline $\begin{array}{l}2^{\text {nd }} \\
\text { survey }\end{array}$ & & & & \\
\hline $\begin{array}{l}3^{\text {rd }} \\
\text { survey }\end{array}$ & & & & \\
\hline $4^{\text {th }}$ & & & & \\
\hline $5^{\text {th }}$ & & & & \\
\hline
\end{tabular}

Using google docs, here's how you find basic statistics:

\begin{tabular}{|c|r|r|}
\hline Name & What to type in (syntax) & Example \\
\hline Mean & =average(beginning cell : & =average(b2:b101) \\
(average) & ending cell) & \\
\hline
\end{tabular}




\begin{tabular}{|c|c|c|}
\hline Median & $\begin{array}{l}\text { =median(beginning cell } \\
\text { ending cell) }\end{array}$ & $=$ median $(\mathrm{c} 2: \mathrm{c} 101)$ \\
\hline Mode & $\begin{array}{l}\text { =mode(beginning cell : } \\
\text { ending cell) }\end{array}$ & $=\operatorname{mode}(\mathrm{d} 2: \mathrm{d} 25)$ \\
\hline $\begin{array}{l}\text { Standard } \\
\text { Deviation }\end{array}$ & $\begin{array}{l}\text { =stdev(beginning cell : } \\
\text { ending cell) }\end{array}$ & $=\operatorname{stdev}(\mathrm{e} 2: \mathrm{e} 50)$ \\
\hline
\end{tabular}

What to turn in:

Each group's survey development team will need to meet with me twice on their questions. ( 3 points each time) - Final surveys due by October 27, 12pm.

(1 point) Choosing the question with the open ended question that prompts participants to give a numerical value, find a confidence interval and provide its interpretation.

(1 point) Each survey has at least one question with only two options. Use your data to find probability of respondents say "yes" or probability of respondents saying "no;" it'll be up to the group as to look at probability of yes or probability of no. Following, pose a question and find its probability.

(2 points) Using one of your survey questions, create a hypothesis test and test against a significance level of your choice.

Data must be gathered by November 4

From each group, the data analysis team will need to meet with me to get help or show me results. (10 points) - Due November 16

\section{Working ahead:}

- Generate argument for the need for change or innovation at COA

- Based on the topic, survey questions and findings, begin finding proposals that address findings and data

- Set up presentation, inputting table of contents, headers for slides and references 
Part 3

1. (100 points) Submit your math analyses for a 3-8 page report on the day of the presentation. Using your data create a compelling argument to convince others the need for change or innovation at COA. Following, write 2 proposals that change or intervene with your findings; one proposal must be from an existing program at another school or in the community.
a. (15 points) Survey Questions, where/when/how did you administer surveys
b. (50 points) Statistical Analysis including measures of center, confidence interval, binomial probability and hypothesis test.
c. (5 points) Create an argument based on the data that convinces others the need for change or innovation at COA
d. (15 points) Description of proposals
e. (10 points) Explanation of how proposals address the data
f. (5 points) References

2. (60 points) Presentation: You will write a proposal that changes or intervenes with your findings; it must be from an existing program at another school or in the community. Additionally, you will create a 5-7 minute presentation.

The presentation will be a condensed version of the written report. For

your presentation, you will need to explain the following:

i. (10 points) Survey questions, where/when/how did you administer surveys

ii. (15 points) Statistical Analysis of data

iii. (5 points) Argument based on the data

iv. (5 points) Description of the proposals

v. (5 points) Connect proposal to data (how do the proposals affect data?)

vi. (5 points) One slide of references.

vii. (5 points) Reporting of materials are clear, well-rehearsed and within time limit.

viii. (10 points) 5 copies of a 1-page handout:

- Argument

- The most compelling data that supports your argument

- Brief summary of the proposals 


\author{
- References \\ - Other stuff that would make it look nice
}

3. (10 points) On the day of the presentations, each group will be designated with a person on campus to send an email outlining your project; the names will be posted on Moodle. This last part will be due Tuesday, December 13. In this email, use professional language, carbon copy (cc) me and share information on the following:
a. You are a student and did surveys on the college.
b. Most compelling piece(s) of data that support your argument
c. Description of your proposals with links
d. Link to your presentation
e. Attach your 1 page handout

( 5 points) Submit a draft to me before submitting to the individual

( 5 points) Submit the email to assigned individual 


\section{Appendix E: MOU Prompt}

\section{Memorandum of Understanding (MOU)}

In this assignment, create a goal for the remainder of the semester. A check-in with me is required for full points. Submit your final MOU, after discussing with me, in a word or pdf document. Check-ins can be done in groups. (15 points). Due 11/15.

Speed dating activity November 13 - share your MOU with a classmate you have not spoken with and write a reflection about what you learned or will do differently based on seeing a colleague's MOU. (10 points)

Write a detailed reflection on how you progressed through your MOU. This will also require a check-in with me after the late November holiday break. Check-ins can be done in groups. ( 25 points) 


\section{Appendix F: Community Building Activities}

\section{Have to/choose to: (15-20 minutes)}

Students fold a sheet of paper the long way (hot dog style, not hamburger). On the left side, they write 3 things they have to do regarding this class or this semester. On the board, I write:

"I have to "I have to "I have to

Students have to write the statements and fill in the blanks on their paper. Following, they all get up and introduce themselves to one another and share their 3 things they have to do. I let that run for a few minutes. On the other half of the paper, students will write the same 3 things, except using different wording. They use the same items they filled in with the "have to" and now use "I choose to" and add a "because" after each. I write the following on the board:

"I choose to _I choose to

I give them a little more time to fill in the "because" portion. Then, they get up again and meet each other, sharing their 3 things. 
Discussion questions - how did it go? How different did it feel the first time versus the second time? Ultimately, we want the students to understand the power of language. The classic example is "I suck at math," something I always bring up at the end of this activity.

\section{Success Quotes: (15-30 minutes)}

I post up 20 quotes ( 5 quotes on 4 sheets of paper) around 4 sides of the room. You can get them into groups before the gallery walk or after, I prefer them to do it before. They walk around the room with a pen and paper and document any quotes or parts of the quotes that stand out; this should go for a few minutes. Then, each group creates their own quotes about success and reports out. To bring it all together, I collect them (with names) and share them towards the end of the semester.

\section{Phone App/Website}

Students get into small groups and determine "characteristics of the successful student in this math class" with groups reporting out - write on board. On another part of the board, have a whole class discussion was to "what you need from me," me being the instructor, and write student suggestions on the board. Then, give each small group a large post-it or something of that size and prompt them to create a phone app or website that would help them succeed in this class. I encourage the artistic ones to showcase their skills. 